\title{
Violência doméstica contra a mulher: representações e práticas do agente comunitário de saúde
}

\author{
Adriana Miranda Ferreira Leite Jacinto
}

Dissertação apresentada ao Programa de PósGraduação em Saúde Pública para obtenção do título de Mestre em Ciências.

Área de concentração: Serviços de Saúde Pública.

Orientador: Prof. Dr. Marco Akerman

Dissertação Revisada

São Paulo

2018 
Dedico este trabalho à minha mãe, Vânia, pelo exemplo de força, coragem e determinação. E a minha filha Helena, a qual desejo que o caminho do conhecimento possa sempre iluminar sua trajetória. 


\section{AGRADECIMENTOS}

Agradeço a Deus, doador de todas as dádivas, pela inspiração à construção dessa dissertação bem como pelas oportunidades e pessoas especiais que contribuíram para a realização desse projeto.

À minha tia Sueli Ferreira Leite por todo apoio, suporte, cuidado e preocupação, fundamentais para a finalização dessa pesquisa.

Ao meu pai Odair Ferreira Leite e a minha mãe Vânia Lúcia Miranda pela contribuição à pesquisa, apoio, suporte e incentivo aos estudos.

À minha tia Vivian Miranda e à Isabelle Santos pela participação em pesquisa, diálogos e discussões pertinentes à temática.

Ao meu esposo Eliézer Jacinto pela paciência, compreensão, incentivo e ajuda durante este percurso.

À minha irmã Emília Miranda Ferreira Leite e à minha filha Helena por tornarem minha trajetória mais alegre!

À minha psicóloga Lígia Varella que acompanhou as alegrias, angústias, perdas, mudanças e passagens no decorrer do mestrado.

Ao meu orientador Prof. Dr. Marco Akerman pela postura empática, acolhedora e autêntica, além do incentivo à pesquisa e disponibilidade de ajuda.

À Prof. Dra. Cristiane da Silva Cabral e a Prof. Dra. Iara Guerriero pela participação no Exame de Qualificação e sugestões oportunas para o Projeto de Pesquisa.

À Prof. Dra. Carmen Simone Grilo Diniz e à Prof. Dra. Márcia Bandini que participaram da Pré-Banca da Pesquisa, com valiosas observações e sugestões para a entrega final do trabalho. À Prof. Dra. Elizabete Franco Cruz que além de sua participação e devolutiva da Pré-Banca, contribuiu assiduamente para o desenvolvimento e aperfeiçoamento dessa pesquisa, com comentários, observações e sugestões preciosas.

À CNPq, pela bolsa de estudos disponibilizada, fundamental para a minha dedicação integral à pesquisa de mestrado, no Programa de Pós-Graduação em Saúde Pública, pela Faculdade de Saúde Pública da USP.

A todos os funcionários da Biblioteca da Faculdade de Saúde Pública da USP pela eficiência do atendimento e prestatividade. 
Às amigas Rebeca Makowiski, Gabriela Dias, Gilmara Ebbers, Márcia Minakawa, Adriana Jarenco, Christiane Soares pela solicitude, diálogos e discussões que vieram a somar e agregar à construção do trabalho.

À Prof. Silmara Conchão, Lúcia Guerra e Cristiane Aranda pelas contribuições técnicas.

Às gerentes das UBSF pela receptividade e colaboração com a proposta de trabalho. Aos profissionais da equipe e da rede de assistência que contribuíram para apoiar a discussão. Em especial, às (os) agentes comunitárias pela abertura e acolhimento da pesquisadora, além da participação nos grupos focais e discussão acalorada da temática. 
O "ser que pode governar a si próprio não tem nada a temer na vida", e essa capacidade de governar-se é adquirida pelo desenvolvimento intelectual que instrumentaliza para a tomada de decisões conscientes e mobiliza para o enfrentamento de preconceitos e de opressões (WOLLSTONECRAFT, 2016, p. 132). 
Jacinto AMFL. Violência doméstica contra a mulher: representações e práticas do agente comunitário de saúde [dissertação]. São Paulo: Faculdade de Saúde Pública da USP; 2018.

\section{RESUMO}

Introdução - Esta pesquisa discute o papel do agente comunitário de saúde (ACS) na identificação dos casos de violência doméstica contra a mulher, considerando sua dimensão e alcance nas relações humanas e os aspectos que contribuíram para sua invisibilidade ao longo da história, além dos prejuízos à saúde e qualidade de vida dos indivíduos, tornando-se um problema de saúde pública. Postula-se que o estudo das representações sociais deste profissional venha a favorecer a efetividade das ações e intervenções da equipe de saúde da família. Objetivo - conhecer e problematizar as representações do ACS sobre a violência doméstica contra a mulher. Método - Convidamos a participar da pesquisa todos os agentes comunitários de saúde das cinco Unidades de Saúde da Família do município de Jundiaí. Foram realizados cinco grupos focais e, para análise das representações sociais, utilizou-se a técnica de Análise de Conteúdo de Bardin. Resultados - As representações dos agentes comunitários quanto ao aspecto privado e particular das relações, bem como a responsabilização da mulher pela compreensão de sua autonomia para romper com o ciclo de violência, despontaram como aspectos desfavoráveis para a reflexão nas questões de gênero, assim como para a elaboração das ações pelos serviços de saúde. A assimilação dessas representações refletiu, inclusive, no distanciamento dos agentes comunitários do contexto de violência contra a mulher, já que para esses profissionais, o limite entre a esfera pública e privada não deve ser ultrapassada sem permissão, consentimento ou pedido de ajuda da mulher. Outros aspectos, como a confusão entre notificação e denúncia, o descrédito na Lei Maria da Penha, o medo de exposição e retaliação na pós-denúncia, a insegurança quanto ao sigilo e a ética dos profissionais de Segurança Pública produziram nos agentes comunitários o desinteresse pela notificação compulsória e a resistência tanto à realização da denúncia, bem como à orientação da mulher a fazer o boletim de ocorrência. Conclusão - Levando-se em consideração a complexidade do problema, aponta-se para a capacitação dos agentes comunitários e demais profissionais da equipe de saúde em uma perspectiva direcionada à abordagem das violências. Entende-se, no entanto, que a formação desses profissionais não 
pode ser pensada à parte de um contexto adverso de organização do serviço, que envolve a terceirização, a precarização e a rotina de trabalho estressante voltada para metas. Logo, não é apenas a capacitação do profissional que irá resolver essa questão, mas a consideração de outros elementos como o engajamento da Saúde na transformação da cultura, principalmente o que concerne às representações de gênero. Dessa forma, a saúde poderá contribuir para práticas transformadoras, viabilizando a discussão em articulação com os movimentos sociais e a sociedade sobre essa possibilidade de mudança.

Descritores: Agente Comunitário de Saúde; Gênero; Violência Doméstica; Violência contra a Mulher. 
Jacinto AMFL. Domestic violence against women: representations and practices of the community health worker [dissertation]. São Paulo: Faculdade de Saúde Pública da USP; 2018.

\section{ABSTRACT}

Introduction - The present research discusses the relevance of the community health worker (CHW) in identifying cases of domestic violence against women, considering their dimension and scope in human relations and the aspects that contributed to their invisibility throughout history, as well as the health and quality of life of individuals, becoming a public health problem. It is postulated that the study of social representations of this professional may favor effectiveness of actions and interventions of the family health team. Objective - to know and to problematize the representations of the $\mathrm{CHW}$ on domestic violence against the woman. Method - all the community health workers from five Family Health Units from Jundiaí were invited to participate in the survey. Five focus groups were carried out and Bardin Content Theme Analysis was used to analyse the social representations. Results - The representations of the community health worker regarding the private and particular aspect of the relations, as well as the women's responsibility for the understanding of their autonomy to break with the cycle of violence, emerged as unfavorable aspects for the reflection on the gender issues as well as for the elaboration of the actions by the health services. The assimilation of these representations also reflected in the distancing of community health worker from the context of violence against women, since for these professionals, the limit between the public and private sphere should not be surpassed without women's permission, consent or request for help. Other aspects such as the confusion between notification and denunciation, disrepute in the Maria da Penha Law, the fear of exposure and retaliation in the post-denunciation and the insecurity about the secrecy and the ethics of Public Safety professionals produced in the community health worker the lack of interest in the notification and the resistance to both the denunciation and the orientation of the woman to make the report of occurrence. Conclusion - Taking into account the complexity of the problem, it is pointed to the training of community health worker and other professionals of the health team in a perspective aimed at approaching violence. It is understood, however, that the training of these professionals can 
not be thought apart from an adverse context of organization of the service, which involves outsourcing, precariousness and stressful work routine geared toward goals. Therefore, it is not only the training of the professional that will solve this question, but the consideration of other elements such as the engagement of health in the transformation of culture, especially with regard to gender representations. In this way, health can contribute to transformative practices, enabling discussion in articulation with social movements and society about this possibility of change.

Descriptors: Community Health Worker; Gender; Domestic Violence; Violence against Women. 


\section{SUMÁRIO}

APRESENTAÇÃO …….................................................................................

1 INTRODUÇÃ O ........................................................................ 17

2 REFERENCIAL TEÓRICO: DIALOGANDO COM A LITERATURA

2.1 INTRODUÇÃO À VIOLÊNCIA DOMÉSTICA CONTRA A MULHER COMO PROBLEMA DE SAÚDE PÚBLICA

2.2 GÊNERO E REPRESENTAÇÕES SOCIAIS: CONCEITOS E ABORDAGENS

2.3 ATUAÇÃO DOS AGENTES COMUNITÁRIOS DE SAÚDE COMO ESTRATÉGIA DE ENFRENTAMENTO À VIOLÊNCIA DOMÉSTICA CONTRA A MULHER: PRODUÇÕES DO CUIDADO

2.4 EDUCAÇÃO PERMANENTE DO AGENTE COMUNITÁRIO DE SAÚDE: CONSTRUÇÃO DE SIGNIFICADOS E TRANSFORMAÇÃO DAS PRÁTICAS DE TRABALHO

$3 \quad$ PRESSUPOSTO …….............................................................. 46

$4 \quad$ OBJETIVOS ................................................................................. 47

4.1 OBJETIVO GERAL ……………………………………………………... 47

4.2 OBJETIVOS ESPECÍFICOS ............................................................. 47

5 PERCURSO METODOLÓGICO ………………………....... 48

$5.1 \quad$ TIPO DO ESTUDO ……………………………………………….... 48

5.2 O CENÁRIO DO ESTUDO ................................................................... 49

5.3 SUJEITOS DA PESQUISA ………………………………………….... 53

5.4. CARACTERIZAÇÃO DOS PARTICIPANTES DA PESQUISA ..... 53

5.5 OS INSTRUMENTOS DE COLETA ………………………………... 53

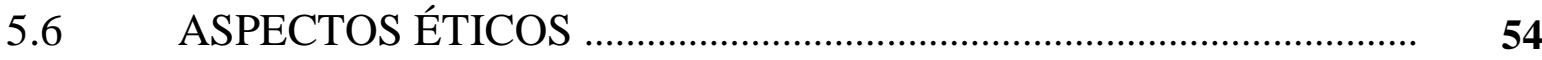


$5.7 \quad$ AS FASES DA PESQUISA ……………….................................... 5

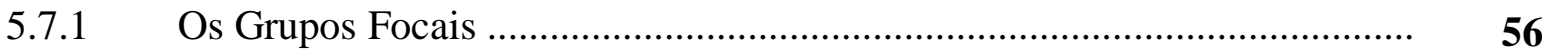

5.8 ANÁLISE DOS DADOS …......................................................... 5

$6 \quad$ RESULTADOS E DISCUSSÃ O.................................................. 5

6.1 REPRESENTAÇÕES DOS AGENTES COMUNITÁRIOS DE SAÚDE SOBRE VIOLÊNCIA CONTRA A MULHER .................... $\quad \mathbf{6 0}$

6.1.1 Concepções dos Agentes Comunitários de Saúde sobre Mulheres em Situação de Violência

6.1.1.1 Fatores que Contribuem para Desencadear ou Reforçar Situações de Violência contra a Mulher

6.1.1.2 O Olhar dos Agentes Comunitários sobre as Justificativas da Mulher para a Permanência em Situação de Violência

81

6.1.1.3 Modos pelos quais as Mulheres Enfrentam a Situação de Violência no Relato dos Agentes Comunitários

6.2 ATENÇÃO À VIOLÊNCIA NOS SERVIÇOS DE SAÚDE E NA 95 REDE DE ASSISTÊNCIA

6.2.1 Representações dos Agentes Comunitários sobre os Serviços de Saúde .....

6.2.1.1 Práticas dos Agentes Comunitários de Saúde a Mulheres em Situação de Violência

7 CONSIDERAÇÕES FINAIS

REFERÊNCIAS

APÊNDICE 1 - TERMO DE CONSENTIMENTO LIVRE E ESCLARECIDO

APÊNDICE 2 - PERFIL DO AGENTE COMUNITÁRIO DE SAÚDE 


\section{LISTA DE ILUSTRAÇÕES}

Figura 1 - Mapa ilustrativo das Unidades de Saúde da Família do município de Jundiaí

Figura 2 - Rede de Atenção à Saúde 51

Figura 3 - Rede de Proteção Social 52

Figura 4 - Serviços de Segurança e Proteção do Cidadão 52

Quadro 1 - Categorias de Análise 


\section{LISTA DE SIGLAS}

AB - Atenção Básica

ACS - Agentes Comunitários de Saúde

APS - Atenção Primária a Saúde

ASACE - Agente de Saúde Ambiental e Controle de Endemias

ATC - Análise Temática de Conteúdo

COJE - Centros de Orientação Jurídica e Encaminhamento

CONFAD - Conflitos familiares difíceis

CRAS - Centro de Referência de Assistência Social

CREAS - Centro de Referência Especializado de Assistência Social

CSEBF - Centro de Saúde Escola Barra Funda

DEAM - Delegacia Especial de Atendimento às Mulheres

DEGES - Departamento de Gestão da Educação na Saúde

ESF - Estratégia Saúde da Família

FCMSC-SP - Faculdade de Ciências Médicas da Santa Casa de São Paulo

FSP/USP - Faculdade de Saúde Pública da Universidade de São Paulo

FUMAS - Fundação Municipal de Ação Social

IDHM - Índice de Desenvolvimento Humano Municipal

LDB - Lei de Diretrizes e Bases

MS - Ministério da Saúde

NASF - Núcleo de Apoio a Saúde da Família

OEA - Organização dos Estados Americanos

OMS - Organização Mundial da Saúde

ONU - Organização das Nações Unidas 
PACS - Programa de Agentes Comunitários de Saúde

PAISM - Programa de Assistência Integral à Saúde da Mulher

PIASS - Programa de Interiorizações de Ações de Saúde e Saneamento

PMAQ - Programa Nacional de Melhoria do Acesso e da Qualidade da Atenção Básica

PNEPS - Política Nacional de Educação Permanente em Saúde

PSA - Programa de Saúde Ambiental

PSF - Programa Saúde da Família

SAS - Serviço de Assistência Social

SUS - Sistema Único de Saúde

TCLE - Termo de Consentimento Livre Esclarecido

TMC - Transtornos Mentais Comuns

UBS - Unidade Básica de Saúde

USF - Unidade de Saúde da Família

UGADS - Unidade de Gestão de Assistência e Desenvolvimento Social

WHO - World Health Organization 


\section{APRESENTAÇÃO}

Meu contato inicial com cenários de violência ocorreu a partir da graduação em Psicologia, mediante os estágios de Psicologia Clínica, Terapia Familiar e Conselho Tutelar, os quais me propiciaram uma aproximação com problemas sociais de ordem estrutural e situações de vulnerabilidade. Meu interesse, no entanto, pela interface violência e saúde surgiu durante o curso de especialização "Psicologia na Rede Básica de Atenção à Saúde" na Faculdade de Ciências Médicas da Santa Casa de São Paulo (FCMSC-SP).

Com a realização desse curso de especialização, passei a estudar os determinantes da violência social e aprofundei o estudo da relação violência e saúde. Assim, as aulas teóricas somadas à prática supervisionada de estágio, no Centro de Saúde Escola Barra Funda (CSEBF), contribuíram para despertar meu interesse pela temática.

$\mathrm{O}$ atendimento em triagens e acompanhamento de casos de mulheres em situação de violência, bem como minha participação em reuniões de matriciamento, interconsulta com a psiquiatria, discussão de grupo com Agentes Comunitários de Saúde (ACS), ida ao Albergue Portal, visita e intervenção à comunidade junto a equipe do consultório de rua permitiram minha aproximação com uma complexa realidade e as múltiplas facetas da violência.

Em minha prática profissional como psicóloga clínica confirmei a frequência dos relatos de violência vivenciados por mulheres em algum episódio de suas vidas. Geralmente, relatos de violência sexual/estupro, em que os membros familiares destacavam-se como principais responsáveis pela incidência e recorrência desses atos violentos.

Desta forma, justifico a relevância da presente pesquisa pela interface entre ACS e violência doméstica contra a mulher, a qual este profissional ocupa posição estratégica no contato direto com as famílias e mulheres em situação de vulnerabilidade do território de sua abrangência. Sendo a violência contra a mulher praticada especialmente em ambiente doméstico, acredito que o estudo das representações sociais sobre o fenômeno possibilitará a compreensão das práticas adotadas por este profissional, além do estabelecimento de espaços para a reflexão e debate com os profissionais de saúde e demais profissionais da rede de assistência.

Nesta perspectiva, gostaria de identificar se existe uma capacitação específica voltada aos ACS com a temática da violência doméstica contra a mulher, e existindo, se corresponde às necessidades e desafios decorrentes de sua prática profissional diária. Logo, entendo que 
processos de educação permanente se fazem necessários e devem incluir os ACS e demais profissionais da equipe de saúde que se encontram, muitas vezes, despreparados para lidarem com esta realidade complexa e multifacetada, reafirmando a invisibilidade cultural da violência doméstica contra a mulher, a qual dificulta, por sua vez, a identificação de novos casos.

Sendo assim, focalizei a pesquisa nas representações sociais e práticas do ACS com relação a violência doméstica contra mulher, em que procuro saber se estas representações interferem na identificação dos casos e práticas deste profissional. Para abordar esta temática, estruturei o trabalho da seguinte forma:

No capítulo 1 apresento a violência social como fenômeno multicausal, na qual a violência doméstica contra mulher ganhou visibilidade na década de $70 \mathrm{com}$ os movimentos feministas em defesa dos direitos das mulheres. Desde então, o debate em torno da temática se fortaleceu e ampliou, por meio de conferências nacionais e internacionais, nas quais a Lei Maria da Penha foi inspirada. Com a visibilidade do fenômeno, políticas públicas foram criadas para erradicar a violência doméstica contra a mulher. Aponto, no entanto, as inúmeras dificuldades que os profissionais de saúde e a rede de serviços encontram para o manejo dos casos. Neste sentido, destaco a necessidade de articulação dos serviços e uma eficaz capacitação dos profissionais.

No capítulo 2 delineio os eixos que fundamentam o trabalho e discorro sobre os aspectos históricos e conceituais do termo "violência doméstica contra a mulher", questões de gênero e representações sociais, como também a problematização da atuação do agente comunitário de saúde e sua relevância na equipe de Estratégia Saúde da Família (ESF) para a identificação dos casos de violência doméstica contra a mulher. Por último, proponho a educação permanente do ACS, tendo em vista a produção do cuidado e a resolutividade das ações.

No capítulo 3 descrevo o pressuposto do estudo. No capítulo 4 menciono os objetivos da pesquisa. No capítulo 5 descrevo o procedimento metodológico citando a natureza da pesquisa, o cenário do estudo, os participantes da investigação, os instrumentos que serão utilizados para a coleta de dados, os aspectos éticos, as fases da pesquisa e a análise dos dados. No capítulo 6 abordo os resultados e a discussão e no capítulo 7 apresento as considerações finais. 


\section{INTRODUÇÃO}

Decorrente das desigualdades sociais e das disputas de poder, a violência manifesta-se como um processo multifacetário. É classificada como a terceira causa de mortalidade geral por causas externas e provoca grande impacto na morbimortalidade da população mundial (WHO, 2009; OMS, 2002). É ainda um "poderoso indicador da qualidade de vida, pois diz respeito às condições gerais da existência, do trabalho e da sociabilidade" (VIEIRA et al., 2003).

Para MINAYO (1994, 2006), a violência é um complexo e dinâmico fenômeno biopsicossocial que conduz a relações hierárquicas de desigualdade, intencionando-se a "coisificar" o ser humano. Trata-se de um caminho oposto ao diálogo, ao reconhecimento e à civilização. Pode ser associada ao impulso de dominar e eliminar o outro, aniquilando sua subjetividade ao tentar transformá-lo em semelhante ou idêntico. (BERENSTEIN, 2001; BARUS-MICHEL, 2011).

Segundo BOURDIEU (2014), a "violência simbólica", por não ser identificada e percebida como violência, é uma das formas mais mortíferas de sua manifestação. Está associada à dominação linguística, ou seja, à incorporação e legitimação de um discurso dominante. Neste caso observa-se que a ordem masculina tem acompanhado os gêneros ao longo de sua reprodução social. Assim, a manifestação do inconsciente androcêntrico pode ser percebida tanto na ordem social como no comportamento de homens e mulheres.

Nesta perspectiva, durante o processo de socialização, a mulher encontra-se sujeita à "violência simbólica" pelo reconhecimento e a incorporação de critérios e padrões do discurso dominante. Neste sentido, os esquemas de pensamento feminino tornam-se produtos dessa ordem simbólica, mediante a naturalização das relações de poder. Logo, a submissão feminina pode ser voluntária, considerando que o efeito da dominação simbólica vai além, muitas vezes, da consciência, da cognição e da vontade, assumindo inclusive a forma de emoções corporais ou de paixões e de sentimentos (BOURDIEU, 2014).

As relações de poder, as formas de silenciamento, submetimento e opressão das mulheres sempre foram temas de interesse e dedicação dos estudos feministas. A temática da violência doméstica contra a mulher, até então silenciada e restrita ao privado, passou a ganhar visibilidade na década de 60 com os movimentos feministas. No Brasil, ganhou força a 
partir da década de 80 e manifestou-se como um problema de saúde pública na década de 90 (VIEIRA et al., 2003).

Atos de violência contra a mulher estão presentes nos mais variados contextos, independente da raça, classe ou cor. Podem se manifestar como agressões verbais, por meio de xingamentos, falas rudes e humilhações. Ou agressões físicas, por meio de tapas, beliscões, empurrões, socos e queimaduras. E ainda, pelo sexo forçado, por medo, coerção física e espancamentos (SCHRAIBER et al., 2005).

De acordo com o Mapa da Violência 2015, no entanto, a população negra é vítima prioritária no índice de homicídios no Brasil. A pesquisa aponta dados alarmantes que revelam o contraste entre os números de homicídios de mulheres brancas e negras. Durante o período de 2003 a 2013, o índice de homicídios de mulheres brancas teve uma queda de 9,8\%, enquanto de mulheres negras houve um aumento de 54,2\% no mesmo período. Em 2003, o índice de vitimização negra era de $22,9 \%$, ou seja, proporcionalmente, morriam assassinadas 22,9\% mais negras do que brancas e em 2013, esse índice chegou a 66,7\% (FLACSO/OPASOMS/ONU MULHERES/SPM, 2015).

De tão frequente e rotineiro, os atos de violência passam muitas vezes despercebidos, sendo considerados como fatalidade, o que potencializa e agrava a banalização da violência. Esses atos praticados contra a mulher são em $80 \%$ dos casos perpetrados por parceiro íntimo, cônjuge, ou ex-parceiro e na maioria das vezes ocorrem em âmbito doméstico (SCHRAIBER et al., 2005).

Mary Wollstonecraft, escritora inglesa do século XVIII, considerada uma das fundadoras do feminismo filosófico, em seu livro: "Uma reivindicação pelos direitos da mulher", denuncia as construções sociais que inferiorizam as mulheres e defende os direitos da mulher à autonomia financeira e emocional, à educação transformadora e à participação na política. Além da crítica ao confinamento doméstico bem como da moda e de atributos exteriores sobrepostos ao desenvolvimento intelectual (apud ESTACHESKI e MEDEIROS, 2017).

A valorização da figura masculina, em detrimento da figura da mulher, é uma marca da sociedade machista, a qual impera nas relações sociais, no imaginário coletivo e no modelo de família tradicional. Esse modelo de família patriarcal, caracterizado pela autoridade do homem sobre a mulher e os filhos, é uma estrutura a qual todas as sociedades contemporâneas estão assentadas. As marcas da dominação e da violência podem ser constatadas na personalidade e nos relacionamentos interpessoais devido ao enraizamento e reprodução desse tipo de estrutura familiar ao longo da história (CASTELLS, 1999). 
Na década de 60 do século XX, no entanto, com a ascensão do movimento feminista e da mulher no mercado de trabalho, os indicadores apontaram para o declínio da família patriarcal. Aos poucos a naturalização da violência contra a mulher foi sendo desmistificada pela ação mundial do feminismo, por meio das análises acadêmicas e dos movimentos sociais, e pela introdução da categoria de gênero. A violência passou a ser vista não mais como fruto das diferenças biológicas, mas como resultado da construção dos papéis sociais impostos a homens e mulheres.

Vale ressaltar que o movimento feminista tem se expressado e caracterizado por meio de algumas "ondas". A "primeira onda" do movimento, no final do século XIX, centralizou suas lutas na reivindicação dos direitos políticos, sociais e econômicos. Foi caracterizada pelo "sufragismo", ou melhor, o direito de voto da mulher. A "segunda onda" surgiu logo após a Segunda Guerra Mundial e se expandiu na segunda metade do século XX, priorizando as lutas pelo direito ao corpo, ao prazer e contra o patriarcado ${ }^{1}$. Foi nesse momento, em que o movimento buscava uma explicação para a subordinação das mulheres, que a categoria gênero foi criada e a violência passou a ser vista não mais como fruto das diferenças biológicas, mas como resultado da construção dos papéis sociais impostos a homens e mulheres (PEDRO, 2005).

Assim, a segunda onda do movimento feminista promoveu propostas de mudanças reais, ancoradas, sobretudo na perspectiva de gênero. Tornou pública a opressão e dominação sofrida pelas mulheres no âmbito do patriarcado e problematizou a abordagem dos conflitos e violência na relação entre homens e mulheres (DEBERT e GREGORI, 2008).

Na década de 60, com a repercussão de alguns trabalhos como, por exemplo, o trabalho de Betty Friedan, "A mística feminina", e o trabalho de Simone de Beauvoir, "O segundo Sexo", os movimentos feministas e de mulheres ganharam maior visibilidade (PEDRO, 2005).

Essa articulação dos movimentos feministas contesta os estereótipos de gênero e o papel social da mulher, possibilitando a desconstrução da identidade feminina associada à fragilidade, passividade e submissão. Desse modo, o aprofundamento nos estudos de gênero contribui para superar o determinismo biológico e destacar a construção das identidades de homens e mulheres, que segundo MOORE (1988), são socialmente construídas, sendo

\footnotetext{
${ }^{1}$ Embora o termo patriarcado seja utilizado por mulheres e algumas correntes feministas, vale ressaltar que o debate feminista contemporâneo questiona a existência de um patriarcado universal, ou seja, de uma força de opressão unificada ou de um sujeito unificado em sua opressão (SCAVONE L. O feminismo e Michel Foucault: afinidades eletivas? In: SCAVONE L, ALVAREZ MC, MISKOLCI, R (Orgs.). O legado de Foucault. São Paulo: EDUNESP/FAPESP; 2006. p. 81-99).
} 
necessário considerar os significados simbólicos associados a tais categorias bem como a variabilidade cultural nas definições de feminilidade e masculinidade, que não devem ser entendidas, por sua vez, como naturais, fixas ou predeterminadas.

$\mathrm{Na}$ década de 80, observa-se que a maioria das mulheres aderiu aos temas e causas feministas, na luta pelo fim da dominação masculina e pela redefinição da identidade da mulher. Assim, ao compartilharem uma fonte de opressão, as mulheres construíram para si uma identidade coletiva, transformando as lutas feministas em movimento feminista. Desde então, o feminismo passou a representar todas as causas da opressão feminina e por meio dele as mulheres tornaram suas reivindicações públicas (CASTELLS, 1999).

Nesta perspectiva, os movimentos feministas na década de 80 no Brasil passaram a exercer pressões sobre o Estado visando o investimento em políticas públicas com recorte de gênero. Assim, surgiram os primeiros serviços específicos para atenção a mulheres em situação de violência: em 1984, os Centros de Orientação Jurídica e Encaminhamento (COJE) e em 1985, a Delegacia Especial de Atendimento às Mulheres (DEAM) (D'OLIVEIRA e SCHRAIBER, 2013).

Vale ressaltar que a luta pelos direitos humanos das mulheres tem sido acompanhada de intensa mobilização internacional, com o envolvimento de governos e de organizações da sociedade civil. Neste sentido, a ONU Mulheres, criada em 2010, destina-se a promover a igualdade de gênero e o empoderamento da mulher, tendo como embaixadora a atriz Emma Watson. Neste cenário, o Brasil destaca-se como signatário de duas convenções internacionais sobre os direitos das mulheres: A Convenção para a Eliminação de Todas as Formas de Discriminação Contra as Mulheres (ONU, 1979) e a Convenção Interamericana para Prevenir, Punir e Erradicar a Violência contra a Mulher, conhecida como Convenção de Belém do Pará (OEA, 1994).

Em 2006 é promulgada a Lei n. 11.340, “nos termos do $8^{\circ}$ parágrafo do art. 226, a qual cria mecanismos para coibir a violência doméstica e familiar contra a mulher”, conhecida como Lei Maria da Penha (BRASIL, 2006). Além de tipificar o crime da violência doméstica e familiar contra a mulher, a Lei Maria da Penha prevê a "necessidade de articulação dos serviços e a capacitação permanente dos profissionais de diversos setores envolvidos em questões de gênero, raça ou etnia" (D’OLIVEIRA e SCHRAIBER, 2013, p. 136).

Neste sentido, em 2007 é lançado o Pacto Nacional para o Enfrentamento da Violência Contra a Mulher, com a finalidade de consolidar a Política Nacional de Enfrentamento à Violência contra as Mulheres por meio da implementação de políticas públicas integradas em todo território nacional (BRASIL, 2011). 
Reconhecer a violência doméstica contra a mulher como problema de saúde e não apenas como demanda da Segurança Pública ou do Judiciário, é fundamental para a identificação dos casos bem como para o planejamento de ações integradas. Assim, os serviços de Atenção Primária à Saúde (APS) assumem papel de destaque através da Estratégia de Saúde da Família, implantada no Brasil em 1994, conhecida anteriormente como Programa de Saúde da Família (PSF) (D’OLIVEIRA e SCHRAIBER, 2013).

Na composição das equipes da ESF estão inseridos os agentes comunitários de saúde, profissionais residentes na comunidade, participantes da realidade, costumes e cultura do bairro onde moram e trabalham. Desse modo, em virtude de sua proximidade dos domicílios e maior possibilidade de vínculo com as famílias, o ACS encontra-se em posição estratégica, funcionando como elo de ligação entre a comunidade e a equipe de saúde (D’OLIVEIRA e SCHRAIBER, 2013).

Dentre as atribuições do ACS espera-se que este profissional seja capaz de identificar indivíduos e famílias em situação de risco, além de compartilhar e discutir com a equipe os casos de vulnerabilidade e participar do desenvolvimento de ações conjuntas (MINISTÉRIO DA SAÚDE, 2012). Logo, conhecer as representações sociais acerca da violência doméstica contra a mulher deste profissional pode contribuir para a identificação dos casos bem como para a compreensão das práticas adotadas.

Para MOSCOVICI (2007), todas as interações humanas pressupõem representações. No encontro com pessoas ou coisas, os significados atribuídos a esses encontros estão atrelados às representações sociais. $\mathrm{O}$ autor aponta para as representações sociais como meio a influenciar o comportamento do indivíduo participante de uma coletividade, enfatizando nesta perspectiva a importância da natureza da mudança.

Segundo MOSCOVICI (2007), a todo o momento, novas representações são formadas e outras são desconstruídas. Por meio delas, o sujeito cria e comunica soluções às suas questões, assume a posição de agente ativo e não meramente de receptor passivo e produto do meio.

No sentido clássico, as representações coletivas referem-se a uma classe geral de ideias e crenças, igualando "toda imagem a uma ideia e toda ideia a uma imagem". Para a Psicologia Social, no entanto, as representações são fenômenos específicos e dizem respeito a uma forma única de compreender, comunicar e criar tanto a realidade como o senso comum (MOSCOVICI, 2007).

Referente às representações de gênero observa-se, não raramente, sua interferência na abordagem dos profissionais ao lidarem com situações de violência doméstica contra a mulher 
(SILVA et al., 2015a). O acolhimento, a escuta e o diálogo são negligenciados em função de um conjunto de ideias preconceituosas e estereotipadas, que responsabilizam a mulher por sua condição e desvalorizam seu sofrimento (SILVA et al., 2015a).

Como afirmam DEBERT e GREGORI (2008), delegar à mulher o desenvolvimento de habilidades e atitudes adequadas capazes de libertá-las das práticas discriminatórias é tão perigoso quanto a crítica à vitimização. Desse modo, para a mulher que não se enquadra nesse perfil são atribuídas características como falta de confiança, autoestima ou dificuldade de comunicação.

Segundo SALIBA et al. (2007), os profissionais de saúde apresentam uma compreensão equivocada ao considerarem a violência como problema exclusivamente de cunho social, cultural ou comportamental. Destacam também a dificuldade desses profissionais em reconhecer a violência como questão de saúde e não apenas de responsabilidade da Segurança Pública e da Justiça.

Nota-se que muitos desses profissionais se posicionam como espectadores, sem um comprometimento efetivo com esta realidade. De acordo com a Portaria GM/MS $n^{\circ}$ 1.271/2014 no Art. $3^{\circ}$, a notificação compulsória é obrigatória para os profissionais de saúde ou responsáveis pelos serviços públicos e privados de saúde. Inclusive, a Lei $n^{\circ}$ 10.778/2003 da mesma portaria, estabelece a notificação compulsória dos casos de violência contra a mulher em território nacional (MINISTÉRIO DA SAÚDE, 2014).

Muito embora a lei disponha quanto à obrigatoriedade ética e legal dos profissionais de saúde em notificar os casos de violência, fundamental para a visibilidade da violência doméstica contra a mulher, este procedimento é extremamente negligenciado. Isto dificulta o dimensionamento epidemiológico do problema e a implementação de políticas públicas direcionadas (SALIBA et al., 2007).

O próprio manejo das ações não configuradas como adoecimentos específicos, embora ocasionem sofrimentos com potenciais danos à saúde, não são considerados com a devida atenção pelos trabalhadores de saúde. No caso da violência doméstica contra a mulher, os estereótipos de gênero, o diagnóstico impreciso, o desconhecimento dos serviços oferecidos em rede, bem como a ausência de mecanismos legais de proteção aos profissionais e a banalização da violência pela própria mulher levam muitos a assumirem uma postura de omissão frente aos casos (D'OLIVEIRA e SCHRAIBER, 2013).

Assim, a integralidade dos serviços disponíveis em rede, o encaminhamento e a realização de parcerias contribuirão para o diagnóstico adequado, bem como para a efetividade do tratamento, o que possibilitará maior qualidade de vida aos usuários. É 
importante considerar, entretanto, a participação e o envolvimento de todos os profissionais, sendo as ações norteadas pelo diálogo, aconselhamento e educação sobre o tema, de forma a contribuir para a conscientização das massas e de sua condição de sujeito (SILVA et al., 2015a).

Nesta perspectiva, vale ressaltar a iniciativa do Ministério da Saúde pela publicação do Caderno de Atenção Básica, volume 8, dedicado à temática da violência intrafamiliar; a iniciativa do Ministério Público de São Paulo pela produção da cartilha: "Mulher, vire a página"; assim como a iniciativa do Coletivo Feminista Sexualidade e Saúde da Faculdade de Medicina da USP pela construção da cartilha "O que devem saber os profissionais de saúde para promover os direitos e a saúde de mulheres em situação de violência doméstica", que se destacam pela importante contribuição aos profissionais de saúde e aos usuários dos serviços (MINISTÉRIO DA SAÚDE, 2001a; SCHRAIBER e D’OLIVEIRA, 2003; MINISTÉRIO PÚBLICO DE SÃO PAULO, 2011).

Segundo FREIRE (1974), a educação dos sujeitos funciona como força de mudança e libertação, além de permitir a autoreflexão e ser uma salvaguarda a um estado de alienação. Neste sentido, a educação permanente em saúde levanta-se como estratégia fundamental para a formação do agente comunitário, que exerce em sua prática profissional importante função como mobilizador social, intermediando e construindo saberes junto à comunidade (ROCHA et al., 2015).

Desse modo, a educação permanente em saúde foi adotada como ação estratégica para operacionalizar a Política de Educação e Desenvolvimento para o Sistema Único de Saúde (SUS), partindo do pressuposto da aprendizagem significativa e reflexão crítica da realidade pelos profissionais de saúde (MINISTÉRIO DA SAÚDE, 2009).

Assim, considera-se que o processo de educação permanente dos ACS poderá contribuir para a transformação e a problematização de suas práticas profissionais, tendo em vista a melhoria na qualidade dos serviços e a coerência das técnicas aplicadas segundo a demanda (ROCHA, et. al., 2015). Dessa forma, o processo de educação permanente torna possível uma capacitação efetiva do agente comunitário de saúde, favorecendo o atendimento e manejo das necessidades dos usuários, além de contribuir para sua autonomia e libertação, de acordo com o modelo de educação proposto por Paulo Freire (FREIRE, 1974). 


\section{REFERENCIAL TEÓRICO: DIALOGANDO COM A LITERATURA}

\subsection{INTRODUÇÃO À VIOLÊNCIA DOMÉSTICA CONTRA A MULHER COMO PROBLEMA DE SAÚDE PÚBLICA}

Desde a década de 60, as lutas empreendidas pelo movimento feminista denunciavam a violência contra a mulher principalmente em âmbito doméstico. Essas mobilizações tinham a finalidade de romper com as dicotomias entre o público e o privado, além de apontar a responsabilização do Estado e da sociedade pela dignidade humana e por uma vida sem violência (GUIMARÃES e PEDROZA, 2015).

O termo violência doméstica foi introduzido no final da década de 1980 no campo da saúde e representou a intersecção entre a violência contra a mulher e a violência intrafamiliar. A ideia de família violenta foi substituída pela ideia de violência praticada em ambiente doméstico. Surgiram também expressões como "mulheres espancadas", "esposa abusada" ou "abuso conjugal". O termo violência contra a mulher passou a fazer parte do senso comum, sendo utilizado como sinônimo de violência doméstica contra a mulher devido à alta incidência de violência nos domicílios (TELES, 2007).

De acordo com a FUNDAÇÃO PERSEU ABRAMO (2001), em importante pesquisa realizada no Brasil quanto à gravidade das violências sofridas pelas mulheres, $43 \%$ das entrevistadas já haviam sofrido algum tipo de violência sexista. Dado mais alarmante foi a constatação de que a cada 2 minutos cinco mulheres são espancadas; a cada 11 minutos 1 estupro é cometido; a cada 90 minutos 1 mulher é assassinada e todos os dias são registrados 179 relatos de agressão pela Central de Atendimento à Mulher (AGÊNCIA PATRÍCIA GALVÃO, 2017).

Em relação ao número de homicídios femininos no Brasil, o país, que ocupava a $7^{\circ}$ posição em 2010, passa a ocupar a $5^{\circ}$ posição em 2013 de uma lista com 83 países. Destaca-se um aumento de $9 \%$ no número de assassinatos registrados, com uma taxa de 4,8 homicídios a cada 100 mil. Segundo o Mapa da Violência 2015, o ranking da violência no País é liderado pelo estado da Roraima, com uma taxa de 15,3 assassinatos para 100.000 mulheres, seguido pelo estado do Espírito Santo com 9,3 e de Goiás e Alagoas com 8,6 (FLACSO/OPASOMS/ONU MULHERES/SPM, 2015). 
Nesta perspectiva, a violência contra a mulher pode ser entendida como um problema de saúde pública, pois, afeta o estado de saúde da população e diz respeito a todos, não apenas aos órgãos de governo para seu enfrentamento (AKERMAN, 2012). Dentre as funções atribuídas à saúde pública pela Organização Pan-Americana da Saúde (OPAS) aponta-se o monitoramento, análise e avaliação da situação de saúde; a vigilância, investigação, controle de riscos e danos à saúde; bem como sua promoção (OPAS, 2002). Dessa forma, o controle dos determinantes sociais de saúde que interferem diretamente nas condições de vida das pessoas pode contribuir para a prevenção e diminuição das violências.

A despeito dos dados alarmantes referentes à violência doméstica contra a mulher, predomina ainda na cultura brasileira o mito da não-violência, o qual mascara e denega a cruel realidade do país. Aliás, muito se fala sobre o tema da violência, porém, raramente de forma substanciosa (CHAUÍ, 2003).

O mito da não violência brasileira oferece explicações simplistas para realidades complexas, pautando-se em mecanismos ideológicos como: a exclusão daqueles que cometem a violência, a distinção da violência como fato isolado e a inversão do real quando se interpreta o machismo como uma proteção à fragilidade feminina (CHAUÍ, 2003).

Relacionando-se com as desigualdades de gênero e as relações de mando e obediência, o mito da não violência é reforçado pelos padrões patriarcais e machistas que regem a sociedade brasileira. Desse modo, importa considerar a pessoa que comete e quem sofre este tipo de violência (CHAUÍ, 2003).

De acordo com SCHRAIBER et al. (2009), o principal agressor, em mais de $80 \%$ das vezes, é o parceiro íntimo ou ex-parceiro. Essa realidade remete, por sua vez, ao ciclo de violência apresentado em 1979 pela psicóloga americana Lenore Walker, descrito em seu livro "The Battered Woman Syndrome". Segundo a autora, o ciclo de violência compreende três fases: $1^{\mathrm{a}}$ Fase: Construção da tensão, $2^{\mathrm{a}}$ Fase: Explosão com incidente de agressão, $3^{\mathrm{a}}$ Fase: Lua de mel com comportamento gentil e amoroso do agressor (WALKER, 1984).

A primeira fase do ciclo de violência é retratada pelo aumento gradual de tensão, por meio de atos discretos a xingamentos, comportamentos intencionais e abuso físico. $\mathrm{O}$ agressor expressa insatisfação e hostilidade, mas não em sua forma extrema. A mulher, por sua vez, procura acalmar e agradar a este agressor, não respondendo à hostilidade do parceiro. Muitas vezes acaba se anulando pela crença irreal de poder controlar o comportamento desse agressor. Ao perceber o constante aumento de tensão, a mulher, temendo causar uma explosão, costuma se retirar. O agressor, no entanto, torna-se mais agressivo ao constatar esse 
movimento por parte da companheira. Desse modo, a tensão continua a evoluir até se tornar insuportável (WALKER, 1984).

A segunda fase é considerada inevitável sem a devida intervenção. A mulher tende a precipitar a explosão para controlar onde e quando ocorre, permitindo que ela tome melhores precauções. Essa fase é caracterizada pela descarga incontrolável das tensões formadas na primeira fase. O agressor desencadeia uma série de ataques físicos e verbais à mulher, provocando ferimentos e traumas emocionais. Quando o agressor interrompe o ataque violento pela diminuição da tensão, essa fase é concluída (WALKER, 1984).

A terceira e última fase é caracterizada pela ausência de violência e tensão. O agressor pede desculpas para sua vítima e se mostra arrependido. Procura ajudar e ser bondoso. Faz promessas e dá presentes. Muitas vezes, inclusive, acredita que não irá repetir novamente o comportamento violento. A mulher, por sua vez, confia nas promessas desse agressor e renova sua esperança pela possibilidade de mudança do parceiro (WALKER, 1984).

O ciclo de violência reflete a intolerância entre os gêneros associada aos aspectos culturais relacionados à construção da consciência, costumes e ideologias, estrutura de classes, bem como a posição e hierarquia social do indivíduo. Esses fatores naturalizam e agravam a invisibilidade da violência. Logo, a mulher, ao solicitar apoio e ajuda no âmbito da justiça e da saúde, muitas vezes torna-se alvo de preconceitos e julgamentos dos profissionais, assim como da opressão e perpetuação de atos agressivos pelo denunciado (BEDONE e FAGUNDES, 2007).

Devido aos preconceitos e estigmas sociais, a violência contra a mulher passou a ser silenciada e naturalizada, infiltrando-se no tecido das relações e destruindo os espaços de convivência e ação comuns. Como consequência, repercutiu no isolamento cada vez maior dos indivíduos e no abandono de horizontes compartilhados (BEZERRA, 2005).

No decorrer da história, os movimentos contraculturais reformadores da relação de gênero tradicional ganharam força e conquistaram direitos no campo jurídico e legal, implementados pelas políticas públicas de equiparação de direito (SCHRAIBER et al., 2009). No Brasil, na década de 1970, destacaram-se manifestações femininas em combate à absolvição de maridos ou ex-maridos culpados dos homicídios de suas esposas. Essas mulheres saíram às ruas e mobilizaram a opinião pública com os versos: "Quem ama não mata, não humilha, não maltrata” (TELES, 2007).

No final do século XX, a violência contra a mulher foi considerada como violação dos direitos humanos, em seus aspectos éticos e legais. A partir de 2003, no Brasil, o novo Código Civil finalmente eliminou todas as discriminações legais contra as mulheres que ainda 
vigoravam e, em 2005, a lei penal eliminou a possibilidade de impunidade do agressor sexual que se casasse com sua vítima (AZAMBUJA e NOGUEIRA, 2008).

Assim, pela pressão ao sistema judiciário, o movimento feminista garantiu o reconhecimento dos direitos das mulheres por meio de mudanças na legislação nacional. Prova disso foi a Constituição Federal de 1988, ao afirmar que todos os homens e mulheres são iguais em direitos e obrigações. Essas conquistas permitiram, na década de 80 , a criação de políticas públicas e serviços específicos, como a delegacia especial da mulher, casas-abrigo e os centros de referência para assistência às mulheres em situação de violência (SCHRAIBER, 2001; SCHRAIBER et al., 2009).

No dia 7 de agosto de 2006, a mulher brasileira alcançou uma das mais importantes conquistas legais com a Lei n. 11.340, mais conhecida como Lei Maria da Penha. Adotada em 2006, como um dos exemplos mais avançados de legislação sobre a violência doméstica e familiar, a Lei Maria da Penha representou um ganho a toda sociedade brasileira. A referida lei garantiu o acesso a tribunais especializados e assistência psicossocial às mulheres, além de romper com uma visão meramente punitiva e incorporar as perspectivas da prevenção, assistência e contenção da violência (CAMPOS, 2015).

Vale ressaltar, que atualmente a Lei Maria da Penha pode vir a sofrer alterações com o artigo 12-B, que confere à autoridade policial o poder jurisdicional de deferir ou negar medidas protetivas de urgência às mulheres em situação de violência, hoje competência exclusiva do Judiciário. A medida proposta tem sido altamente criticada, pois, viola direitos e fere o paradigma do Estado democrático, além de sua inconstitucionalidade evidente, ao trocar uma garantia jurisdicional por uma medida administrativa precária (AGÊNCIA PATRÍCIA GALVÃO, 2016).

Dentre as violências cometidas contra a mulher encontram-se a violência física, a violência sexual, psicológica, patrimonial e moral. A violência física consiste no uso da força para provocar lesões corporais, dor ou incapacidade, sendo realizada por uma pessoa em situação de poder em relação à outra (MINAYO, 2006).

No art. $7^{\circ}$, inciso III da Lei Federal n. 11.340/2006, denominada Lei Maria da Penha, a violência sexual é entendida como:

[...] qualquer conduta que constranja a mulher a presenciar, a manter ou a participar de relação sexual não desejada, mediante intimidação, ameaça, coação ou uso da força; que a induza a comercializar ou a utilizar, de qualquer modo, a sua sexualidade, que a impeça de usar qualquer método contraceptivo ou que a force ao matrimônio, à gravidez, ao aborto ou à prostituição, mediante coação, chantagem, 
suborno ou manipulação; ou que limite ou anule o exercício de seus direitos sexuais e reprodutivos (BRASIL, 2006).

A violência psicológica envolve atitudes e condutas que resultam em medo, frustração, temor quanto à própria integridade física e psicológica, ameaças verbais e emocionais. Dentre as modalidades de violência é a mais recorrente e difícil de ser identificada. Refere-se aos impactos à saúde emocional, à autoestima e ao pleno desenvolvimento humano, levando o indivíduo a sentir-se desvalorizado, rejeitado e ansioso. Como consequência da humilhação pública a base de ameaças, isolamento e exploração, o sujeito adoece e, em última instância, comete o suicídio (MINISTÉRIO DA SAÚDE, 2001a).

A Lei Federal n. 11.340/2006 considera também outros dois tipos de violência: patrimonial e moral. A violência patrimonial no art. $7^{\circ}$ inciso IV dessa Lei é entendida como qualquer conduta que configure retenção, subtração, destruição de objetos, documentos pessoais, bens e valores. Já a violência moral no art. $7^{\circ}$ inciso $\mathrm{V}$ é entendida como qualquer conduta que configure calúnia, difamação ou injúria (BRASIL, 2006).

Outro foco de análise desta pesquisa refere-se à tipologia da violência, na qual a violência doméstica está inserida e destaca-se como importante questão social pelos estudos dos conflitos familiares. Vale ressaltar que a violência doméstica difere-se da violência intrafamiliar por incluir outros membros do grupo, sem função parental que convivam no espaço doméstico, dentre eles: empregados, agregados e visitantes esporádicos (MINISTÉRIO DA SAÚDE, 2001a).

Geralmente, a violência doméstica é praticada por um membro da família que convive com a vítima, sendo considerada uma resultante de um processo de ações ou omissões que prejudicam o bem-estar, a integridade física, psicológica, a liberdade e o direito ao pleno desenvolvimento do indivíduo inserido em convivência familiar, impactando a saúde pública (MINISTÉRIO DA SAÚDE, 2001a).

Por meio das reivindicações dos movimentos feministas e com a legalização dos direitos das mulheres, o debate da violência doméstica contra a mulher ganhou força e tem se ampliando não apenas no âmbito social, jurídico e da Segurança Pública, mas também nos serviços de saúde (LEAL et al., 2011). Observa-se, no entanto, que a violência contra a mulher se apresenta de forma implícita nos serviços de saúde, não sendo reconhecida, muitas vezes, como problema inerente à sua atenção (OLIVEIRA e FONSECA, 2014).

Frequentemente, mulheres em situação de violência procuram os serviços de saúde e dão queixa, mas não falam da violência sofrida. Aparecem com um "deslocamento da retina", "um braço quebrado" ou outro tipo de traumatismo, entretanto, raramente revelam a causa 
desse sofrimento. Normalmente por medo, vergonha, por não terem com quem conversar ou por acharem que "não vai fazer nenhuma diferença" (SCHRAIBER, 2005).

Assim, aponta-se para a necessidade de uma cultura institucional nos serviços de saúde voltada à identificação de mulheres em situação de violência, bem como, ações nas quais os profissionais estejam instrumentalizados e respaldados para enfrentar esta realidade, uma vez que, as próprias profissionais de saúde, relatam as vivências pessoais de violência como aspectos a influenciarem suas percepções e atitudes diante deste cenário (LEAL et al., 2011).

Com o índice notório de homicídios femininos, confirma-se a primazia de uma cultura institucional voltada à identificação de mulheres em situação de violência, não apenas nos serviços de saúde, mas em toda a rede de assistência. Nesta perspectiva, houve um grande progresso no dia 9 de março de 2015, com a declaração da Lei n. 13.104/2015, conhecida como Lei do Feminicídio. Essa lei expressa o caráter sexista dos homicídios que ocorrem nas relações de gênero. Em São Paulo, por exemplo, o homicídio é considerado a principal causa de morte de mulheres entre 15 e 49 anos de idade. Acredita-se que $80 \%$ desses crimes estejam associados à violência doméstica e sexual. Estima-se que o feminicídio seja, possivelmente, um dos crimes mais subnotificados, pois, não se sabe ao certo quantas mulheres são assassinadas pelo parceiro ou cônjuge (TELES, 2007).

A subnotificação dos casos de violência doméstica contra a mulher e o pacto de silêncio nos lares, somados à falta de preparo e capacitação dos profissionais de saúde, agravam a invisibilidade do comportamento violento (CARNASSALE, 2012). Os dados policiais apontam apenas para a violência denunciada e os serviços de saúde, mesmo conscientes da compulsoriedade da notificação, com a Lei n. 10.778 de 24 de novembro de 2003, referente à notificação compulsória da violência contra a mulher em território nacional, raramente notificam ou registram, confundindo notificação com denúncia policial (TELES, 2007).

A subnotificação da violência contra a mulher dificulta a elaboração de políticas públicas e medidas efetivas. Diante deste cenário, alguns mitos são propagados e reforçados, como aqueles que declaram que as mulheres agredidas fazem parte de uma pequena porcentagem da população e gostam de apanhar. Ou ainda, a justificativa das agressões devido ao consumo de álcool e drogas, a baixa escolaridade e condições socioeconômicas desfavoráveis dos agressores (TELES, 2007).

Assim, para uma possível desnaturalização da violência doméstica contra a mulher, aponta-se a Estratégia de Saúde da Família (ESF), considerada porta de entrada para o 
atendimento na rede de atenção à saúde, sendo um dos principais serviços capazes de atuar preventivamente sobre as formas de violências sofridas por mulheres (D'OLIVEIRA e SCHRAIBER, 2013).

Dessa forma, pela posição estratégica a qual os serviços de saúde se encontram, torna-se possível a identificação e o acolhimento de mulheres em situação de violência doméstica, sendo a escuta do profissional e a investigação da queixa aspectos fundamentais para a sensibilização e a visibilidade da questão como problema de saúde pública (LEAL et al., 2011).

\subsection{GÊNERO E REPRESENTAÇÕES SOCIAIS: CONCEITOS E ABORDAGENS}

Para contextualizar a violência doméstica contra a mulher é necessária uma maior compreensão do conflito entre os sexos, discutindo-se o conceito de gênero. O termo "gênero" passou a ser utilizado por feministas norte-americanas e inglesas na década de 80 no lugar de "sexo", com o intuito de combater o determinismo biológico utilizado para explicar as desigualdades sociais entre os sexos. Defendiam que as diferenças encontradas no comportamento de homens e mulheres não estavam ligadas ao "sexo", mas sim ao "gênero", logo, estariam relacionadas à cultura e não às questões biológicas. Assim, a categoria gênero passou a enfrentar o desafio de se contrapor à visão tradicional conservadora de aceitar como "natural" a invisibilidade e a desvalorização social das "ditas características femininas" (PEDRO, 2005; TELES, 2007).

No início desse movimento de "segunda onda", no entanto, a categoria utilizada não era gênero, mas sim, "Mulher", contrapondo-se à categoria "Homem", considerada universal e a qual as mulheres não se sentiam incluídas e representadas, tendo em vista questões específicas inerentes às mulheres como o direito de ter filhos quando quiser e se quiser. Deste modo, as feministas afirmavam uma identidade da "Mulher" separada da identidade do "Homem". Assim, todas as pessoas que possuíam o sexo feminino eram entendidas como

"Mulher" e, portanto, passavam a ser pensadas como submetidas ao sexo masculino e às mesmas formas de opressão. Este "separatismo" fez com que fossem consideradas "diferencialistas". Logo, foram acusadas de "essencialistas" ao apontarem o sexo genital como responsável pela diferença entre homens e mulheres, o que lhes garantia, em sua perspectiva, a identidade para as lutas contra a subordinação. Dessa forma, enquanto as 
"igualitaristas" reivindicavam que as mulheres participassem na esfera pública com os mesmos direitos e igualdade de condições que os homens, as "diferencialistas" preconizavam a "feminização do mundo" (PEDRO, 2005).

A categoria "Mulher" passou a ser substituída pela categoria "Mulheres", já que a primeira era alvo de inúmeras interpretações e críticas e não correspondia à diversidade do grupo de mulheres, tais como mulheres negras, índias, mestiças, pobres, trabalhadoras que reivindicavam a diferença dentro da diferença. Logo, o fato de ser uma mulher, não significava necessariamente possuir as mesmas causas de opressão. Deste modo, a identidade de sexo não seria suficiente para juntar as mulheres em torno de uma mesma luta (PEDRO, 2005).

Embora as diferenças entre as mulheres tenham sido evidenciadas, não é possível esquecer as desigualdades e as relações de poder entre os sexos. Neste sentido, as feministas observaram que as mulheres, em diferentes sociedades, eram submetidas à autoridade masculina, nas mais diversas formas e diferentes graus, além das atividades culturalmente atribuídas às mulheres serem sempre desqualificadas em comparação as atividades atribuídas aos homens (PEDRO, 2005).

Através dos estudos de gênero constata-se como o poder masculino tem subordinado a população feminina e como essas relações sociais se desenvolvem. Observa-se que a incorporação das estruturas históricas de ordem masculina acompanham os gêneros ao longo de sua reprodução social, sendo a manifestação do inconsciente androcêntrico percebida na ordem das coisas bem como no comportamento de homens e mulheres (TELES, 2007; BOURDIEU, 2014).

Desse modo, a desigualdade entre os sexos é estabelecida pela legitimação da dominação masculina, de maneira a tornar o sexo feminino como um fenômeno menos valorizado ou até mesmo com características negativas. Assim, as arbitrárias divisões entre os sexos, ao considerar as diferenças anatômicas entre eles como naturais e evidentes, acentuam as desigualdades entre homens e mulheres (TELES, 2007; BOURDIEU, 2014).

Dentre os estudos feministas de gênero, verifica-se que não são propriamente as características sexuais que irão definir o que é feminino e masculino, mas a forma como essas características são representadas ou valorizadas em uma determinada sociedade, ou seja, para compreender o lugar e as relações entre homens e mulheres, importa observar tudo o que socialmente se construiu sobre os sexos em uma determinada sociedade (LOURO, 2014).

Neste sentido, não se pretende negar que o gênero se constitui sobre os corpos sexuados, ou melhor, não é negada a biologia, porém, valoriza-se a construção social e 
histórica das características biológicas. Assim, procura-se acentuar “o caráter fundamentalmente social das distinções baseadas no sexo" (SCOTT, 1995, p. 72).

Para SCOTT (1995) a categoria de gênero está associada à noção de poder. A autora afirma que o gênero é constituído por relações sociais e pode ser entendido pelas diferenças percebidas entre os sexos, concebidas no interior de relações de poder. Historicamente, a relação de dominação e desigualdade na distribuição do poder entre homens e mulheres sempre se fez presente e foi considerada como um fator gerador de violência. Durante séculos, as mulheres foram educadas a se submeterem aos homens, o que contribuiu para naturalização da violência no cotidiano das interações em diversas sociedades.

Nesta perspectiva, a figura masculina foi construída como símbolo de força, poder e dominação e a figura feminina como símbolo de fragilidade, pureza e submissão. O homem como mantenedor da família, estaria vinculado à esfera pública, enquanto a mulher, responsável pelos filhos e cuidados domésticos, estaria vinculada à esfera privada (BOURDIEU, 1995).

Nos estudos feministas de gênero, as relações desiguais de poder são apresentadas como consequência de uma construção de representações e funções de subordinação, submissão e opressão da mulher, por meios institucionais, educacionais e sociais. A desigualdade na distribuição de poder entre homens e mulheres pode ser percebida inclusive no que tange à sexualidade, reprodução, divisão sexual do trabalho bem como em âmbito público e privado (TELES, 2007).

A categoria gênero traz uma característica relacional e hierárquica entre pessoas do mesmo sexo e de diferentes sexos. Inclui a relação entre as próprias mulheres, os próprios homens e as relações entre mulheres e homens. Além disso, se constrói em um tempo histórico vivido em cada sociedade, se relacionando com outros determinantes sociais como classe, raça, etnia, idade, localização geográfica, orientação sexual, dentre outros. Por isso, não se deve confundir o termo gênero como sinônimo de mulher, o que seria um reducionismo de seu significado (CABRAL e DÍAZ, 1998; TELES, 2007).

A característica social e relacional do conceito de gênero não deve levar a compreensão de uma construção de papéis masculinos e femininos, já que papéis pressupõe a ideia de padrões ou regras arbitrárias que definem os comportamentos de determinada sociedade. Desse modo, a aprendizagem de papéis sugere que cada um deveria conhecer os comportamentos adequados e inadequados para um homem e uma mulher e corresponder a essas expectativas. Essa visão, no entanto, se mostra muito redutora ou simplista (LOURO, 2014). 
Diferente do conceito de sexo, que define as características biológicas de cada indivíduo, o termo gênero diz respeito à construção cultural e coletiva dos atributos da masculinidade e feminilidade, que torna as diferenças entre homens e mulheres socialmente significadas. É ainda um conceito plural, que varia entre as sociedades e sujeitos de diferentes classes, raças, gerações e religiões, suprimindo as similaridades entre os sexos e exacerbando suas diferenças (RUBIN, 1975; SCOTT, 1995; LOURO, 1996).

A ideia é entender o gênero como parte do sujeito, constituindo sua identidade. As identidades de gênero e as identidades sexuais, por sua vez, não são dadas ou acabadas em um determinado momento. O enfoque é sempre no processo, em algo que está em construção e não em algo que já existia anteriormente. Como afirma LOURO (2014, p. 28), os sujeitos apresentam "identidades plurais, múltiplas; identidades que se transformam, que não são fixas ou permanentes, que podem até mesmo ser contraditórias". Assim, ao se referir e utilizar o conceito de gênero é importante considerar as distintas sociedades e os distintos momentos históricos.

Da mesma forma que a história da sexualidade é constituída por inúmeros discursos sobre o sexo, que regulamentam, normalizam e instauram saberes e "verdades", as identidades de gênero também são construídas pela identificação dos sujeitos, social e historicamente, como masculinos e femininos (LOURO, 2014).

O termo gênero, além de ter sido utilizado pelas primeiras feministas para repudiar o determinismo biológico, ganhou outros destaques. Algumas estudiosas interpretaram gênero como um instrumento de análise das relações entre mulheres e homens; outras utilizaram o termo para investigar a alienação e a coisificação das diferenças humanas. Houve aquelas que se referiram ao gênero para mostrar como se dá a distribuição de cargas e benefícios na sociedade; outras pesquisaram a semiótica do corpo, o sexo e a sexualidade. Algumas estudiosas se debruçaram em compreender as microtécnicas do poder; para entender a estrutura da psique; e ainda para aprofundar o conhecimento da identidade e das aspirações individuais (TELES, 2007).

Embora gênero não seja o mesmo que falar em feminismo, é fato que as feministas contribuíram para esse debate trazendo o conceito de "diferenças", "forma elementar de diversidade" e o aspecto de "relações sociais de poder". Além disso, os estudos de gênero só foram possíveis com a ação concreta do feminismo (TELES, 2007).

Para BOURDIEU (1995), as representações do feminino e do masculino refletem uma cultura machista e patriarcal, na qual os corpos socializados aceitam sem reflexão a naturalização dos padrões de comportamento pautados no referencial masculino. Tais 
representações construídas ao longo da história, a qual homens e mulheres encontram-se em oposição binária, desvela o aprisionamento masculino à condição de agente e causador da violência, em contra partida a mulher, em posição de vítima (ALVES et al., 2012).

Para SCOTT (1995), a oposição binária masculino-feminino e o processo social das relações de gênero atribuem sentido às relações de poder. Enfatiza, no entanto, a importância da desconstrução do caráter permanente dessa oposição bem como do pensamento dicotômico e polarizado sobre os gêneros, em que homens e mulheres são concebidos como polos opostos em uma lógica invariável de dominação-submissão. Assim, observa que a desconstrução da polaridade rígida dos gêneros, possibilitaria problematizar tanto a oposição entre eles, quanto a unidade interna de cada um, demonstrando que a oposição é construída e não inerente e fixa.

Nesta perspectiva, o polo feminino contém o masculino e vice e versa, sendo cada um desses polos internamente fragmentado e dividido. Afinal não existe a mulher, mas várias mulheres, com características diferentes entre si. Como consequência dessa desconstrução, as diferentes formas de feminilidade e masculinidade que se constituem socialmente ganhariam visibilidade, tornando-se possível compreendê-las e incluí-las (LOURO, 2014).

Segundo MINAYO (2008), as representações sociais manifestam-se por meio da linguagem e são definidas como categorias de pensamento, de ação e de sentimento que explicam, justificam e questionam a realidade. Estas representações são resultantes da interação social de um grupo de indivíduos e caracterizam um conjunto de explicações, crenças e ideias que permitem evocar um dado acontecimento, pessoa ou objeto.

SPINK (1993) assinala que as representações sociais incluem o conhecimento do senso comum, formas de conhecimento prático manifestadas em elementos cognitivos como: imagens, conceitos, categorias e teorias. Além de considerar a representação como uma construção contextualizada do sujeito como ser social.

Oriundo da sociologia clássica de Durkheim, o termo representação social ganhou destaque e profundidade nas teorias da psicologia social desenvolvidas por Serge Moscovici e aprofundadas por Denise Jodelet, que passaram a servir de referencial para outros campos do saber, como a saúde, a educação, a didática e os estudos socioambientais.

A definição mais utilizada é a de JODELET (2001, p.22): “As representações sociais são uma forma de conhecimento socialmente elaborado e compartilhado, com um objetivo prático, e que contribui para a construção de uma realidade comum a um conjunto social”.

A autora ressalta que as representações sociais devem ser estudadas considerando-se os elementos afetivos, mentais e sociais e integrando, ao lado da cognição, da linguagem e da 
comunicação, as relações sociais que formam e afetam tais representações e a realidade material, social e ideal sobre a qual elas vão intervir (JODELET, 2001).

Enfatiza também a importância da análise do conjunto de componentes e relações contidas nas representações sociais e destaca três questões fundamentais: quais os atores que as emitem e de onde falam; qual o seu conteúdo e sobre qual objeto ou aspecto essa percepção está sendo construída, e como incide sobre seu comportamento ou socialmente (JODELET, 2001).

Para MOSCOVICI (1989), as representações são produzidas e apreendidas no contexto das comunicações sociais, são necessariamente estruturas dinâmicas, flexíveis e permeáveis. Uma relação íntima entre linguagem e ação. As representações estão presentes nas interações humanas e uma vez criada adquirem vida própria, constituindo uma realidade social.

Todo encontro com pessoas ou coisas pressupõem-se representações. Assim, os significados atribuídos a esses encontros estão atrelados às representações sociais. Logo, novas representações são formadas e outras são descontruídas. Por meio delas, o sujeito cria e comunica soluções às suas questões, assume a posição de agente ativo e não meramente de receptor passivo e produto do meio (MOSCOVICI, 2007).

Nesta perspectiva, o autor enfatiza a importância da natureza da mudança, apontando para as representações sociais como meio a influenciar o comportamento do indivíduo participante de uma coletividade. Assim, a teoria das representações sociais trata a produção dos saberes sociais, centrando-se na análise da construção e transformação do conhecimento social (MOSCOVICI, 2007).

Dentre as representações sociais da mulher quanto as suas responsabilidades no casamento, destaca-se a obrigatoriedade em manter relações sexuais com o marido e a necessidade de permanecer no matrimônio a despeito das agressões e ameaças. Frequentemente, a violência doméstica contra a mulher aparece como "intrínseca à relação conjugal", sendo tolerada como medida repressiva e corretiva, de responsabilidade individual, protegida pelo silêncio sobre o que acontece entre quatro paredes (MOREIRA et al., 1992).

Desta forma, muitas mulheres confinam-se ao espaço privado, sem opinar ou se queixar. Acreditam serem responsáveis pela agressão sofrida e legitimam a violência praticada, como se essa fosse um direito do parceiro. Desconhecem seus direitos como mulheres e permanecem aprisionadas às representações de gênero, reproduzindo e perpetuando padrões de comportamentos pré-concebidos (DINIZ e PONDAAG, 2004). 
Nos serviços da rede pública, comumente, os profissionais lançam mão dos estereótipos de gênero, pressupondo que as mulheres desejam ser subjugadas ou inferiorizadas, valendo-se de mentiras para proteger seus parceiros violentos (KISS e SCHRAIBER, 2011). Sendo as representações socialmente produzidas, considera-se que os profissionais de saúde, neste caso os ACS, tenham representações comuns em sua área de atuação, o que possibilita trocas simbólicas com a comunidade e a equipe.

Estudo realizado com agentes comunitários de saúde em um município da região noroeste do Rio Grande do Sul, com o intuito de compreender a violência contra a mulher no discurso desses profissionais, revelou, por meio de entrevista semiestruturada e análise de conteúdo temática, a dominação masculina em relação à feminina. Além disso, associou-se à figura da mulher a delicadeza, subordinação, obediência, procriação e cuidados domésticos. E a figura masculina ao poder, autoridade, ao papel de provedor e chefe do lar (HESLER et al., 2013).

Neste cenário, acredita-se que as representações dos ACS, socialmente construídas, venham a contribuir para a identificação dos casos de violência doméstica contra a mulher bem como em suas práticas. A visita domiciliar e os laços estabelecidos com as famílias e a comunidade reforçam e possibilitam a identificação dos casos de violência. Assim, os agentes comunitários de saúde podem atuar na prevenção como também na notificação e denúncia da violência (MINAYO, 2004).

\subsection{ATUAÇÃO DOS AGENTES COMUNITÁRIOS DE SAÚdE COMO ESTRATÉGIA DE ENFRENTAMENTO À VIOLÊNCIA DOMÉSTICA CONTRA A MULHER: PRODUÇÕES DO CUIDADO}

O Programa de Agentes Comunitários de Saúde (PACS) foi desenvolvido em 1991 pelo Ministério da Saúde (MS) em vários estados brasileiros após experiência bem-sucedida no Estado do Ceará. Em março de 1994, surge então o Programa de Saúde da Família (PSF), no qual os agentes comunitários passam a compor as equipes de saúde da família, provocando mudanças significativas no processo de trabalho em saúde (GUEDES et al., 2011).

O desenvolvimento do PACS foi uma resultante do Programa de Interiorizações de Ações de Saúde e Saneamento (PIASS), a princípio implantado no Nordeste, entre 1976 e 
1979, e posteriormente implantado em outras regiões como o Vale do Ribeira, no Estado de São Paulo, entre 1980 e 1987, ficando conhecido como Projeto Devale (GUEDES et al., 2011).

Em Pernambuco, no Estado de Recife, além do Programa de Agentes Comunitários, a cidade é pioneira na implantação do Programa de Saúde Ambiental (PSA) em 2002, responsável pelas ações de vigilância, promoção da saúde, prevenção e controle de doenças e agravos, além de sua colaboração na proteção do meio ambiente por meio dos Agentes de Saúde Ambiental e Controle de Endemias (ASACE) (PREFEITURA DE RECIFE, 2018).

O Programa Saúde da Família, conhecido atualmente como Estratégia Saúde da Família, foi uma proposta desenvolvida visando à implementação do SUS e a contribuição para sua efetividade. Através da Constituição Federal de 1988 e das leis n.8.080/1990 e n.8.142/1990, algumas transformações ocorreram no sistema brasileiro de proteção social em saúde, seja ao afirmar o dever do Estado e a garantia de direitos, seja ao promover seus pressupostos de universalização, descentralização, integralidade e participação social (CARDOSO e NASCIMENTO, 2010).

A Estratégia Saúde da Família representou um avanço na história de saúde pública do Brasil com a expansão e a qualificação da atenção básica. Tendo como objetivo o desenvolvimento de práticas gerenciais e sanitárias, democráticas e participativas sob a forma de trabalho em equipe, dirigidas a populações de territórios delimitados com a finalidade de promover a saúde das famílias em uma nova dinâmica (PEDROSA e TELLES, 2001).

Ao priorizar a família em seu espaço físico e social, esta nova estratégia proporciona à equipe de saúde uma compreensão ampliada do processo saúde-doença para além das práticas curativas e oportuniza a ação interdisciplinar entre os profissionais. Nesta perspectiva, destaca-se a importância da identificação dos profissionais de saúde com as propostas de trabalho, buscando estratégias inovadoras para os projetos comunitários e em grupo (TRAD e BASTOS, 1998).

Uma equipe de Estratégia Saúde da Família é responsável pelo acompanhamento de seiscentas a mil famílias, não devendo ultrapassar o limite máximo de 4.500 pessoas. É composta basicamente por um médico, um enfermeiro, um auxiliar de enfermagem e quatro a seis agentes comunitários de saúde. No caso dos agentes comunitários de saúde, estes são responsáveis pelo acompanhamento de aproximadamente 150 famílias (MINISTÉRIO DA SAÚDE, 2001b).

Como membro efetivo da Estratégia Saúde da Família, verifica-se que o ACS exerce o papel de mediador e tradutor dos conhecimentos científicos da equipe de saúde e dos saberes 
populares da comunidade, em razão do convívio com a realidade, cultura, linguagem, costumes e práticas de saúde do bairro onde mora e trabalha (DUART et al., 2007).

Dentre as atribuições específicas dos ACS destacam-se: a tradução para a equipe de saúde da dinâmica social da comunidade, suas necessidades, potencialidades e limites; a identificação de parceiros e recursos existentes na comunidade que possam ser otimizados pelas equipes; além da promoção da educação e a mobilização comunitária, visando desenvolver ações coletivas de saneamento e melhoria do meio ambiente. Tais atribuições são necessárias ao cuidado integral do usuário e estimulam a corresponsabilidade na melhoria da qualidade de vida e saúde da população (TAVARES, 2002).

Com a nova Portaria 958/16, lançada em 11 de maio de 2016, os agentes comunitários de saúde deixam de pertencer obrigatoriamente à composição das equipes de Estratégia Saúde da Família, perdendo suas atribuições previstas em Lei n. 11.350/06. Estes profissionais poderão ser substituídos pelos técnicos de enfermagem tendo em vista os argumentos de "ampliação das possibilidades de composição das equipes de Atenção Básica" e o "aumento da capacidade clínica na Unidade Básica de Saúde e o cuidado no domicílio, fortalecendo a continuidade da relação clínica na construção de vínculo e responsabilização, bem como a ampliação da resolutividade na Atenção Básica" (ENSP, 2016).

Esta classe profissional, entretanto, desempenha um papel fundamental para o desenvolvimento da assistência e consolidação da Estratégia de Saúde da Família (CORDEIRO, 2005). Por meio do vínculo formado entre as famílias e o ACS, torna-se possível identificar mulheres e famílias em situação de vulnerabilidade e risco. Este profissional também pode contribuir para a elaboração de intervenções, para facilitar o trabalho de vigilância e promoção da saúde dos usuários dos serviços (DUART et al., 2007).

Com a iminência da nova Portaria 958/16, temporariamente suspensa, coloca-se em cheque os fundamentos da Estratégia Saúde da Família. Perde-se o enfoque na medicina comunitária, no território, nas práticas de promoção e prevenção de agravos, reforçando as práticas biomédicas e meramente curativas. A retirada do ACS da equipe mínima trata-se de um retrocesso ao modelo de saúde ancorado na participação popular e educação popular (ENSP, 2016).

O cuidado integral da saúde representa um grande desafio à assistência, pois, envolve a mudança no modelo de atenção "procedimento centrado" para um modelo de atenção "usuário centrado" (MERHY, 2002). O desenvolvimento de estratégias efetivas para o cuidado integral de mulheres em situação de violência doméstica requer, por sua vez, o compartilhamento das ações em equipe e a superação da fragmentação dos serviços. 
Dentre as fragilidades que dificultam a integralidade do cuidado aponta-se o despreparo dos profissionais em lidar com situações de violência e sua atitude, muitas vezes, de omissão frente aos casos. Considera-se também, a concepção desses profissionais sobre a violência e suas causas, a fragmentação das ações e a relação que se estabelece com a família e a rede intersetorial (MOREIRA el al., 2014).

Falar de cuidado em saúde significa também falar sobre a vida, a qual todos os seres humanos estão envolvidos e são responsáveis. Nesta linha de raciocínio, a vida e a saúde do indivíduo remetem a um projeto de felicidade, no qual cada ser humano deposita seus desejos, motivações e expectativas (FEUERWERKER, 2013). Sendo assim, o cuidar é tema da produção do humano e alcança não apenas a área da saúde como também, diz respeito à teia de relações e encontros que conformam vida.

O cuidado em saúde diz respeito à produção de atos que ocorrem no encontro entre agente produtor com seus conhecimentos, equipamentos e concepções, e agente consumidor com suas intencionalidades, conhecimentos e concepções. Envolve ainda intervenções inovadoras que alcancem não apenas as coletividades, mas também o cuidado individual, no qual o usuário assume uma dupla função: tanto de objeto do ato produtivo como de agente ativo a interferir no processo (FEUERWERKER, 2014).

Para MERHY (1998) o trabalho em si pode ser compreendido como "trabalho vivo em ato", o qual se destina a consumir o "trabalho morto", caracterizado pelos instrumentos e a organização de trabalho. Assinala que o "trabalho vivo em ato" tem como finalidade a produção do cuidado e afirma que o encontro entre profissional-usuário se dá por meio de “caixas de ferramentas tecnológicas". Sendo a primeira caixa referente aos diagnósticos e procedimentos, a segunda caixa aos saberes e a terceira caixa à relação trabalhador-usuário (MERHY, 2009).

Segundo o autor, a primeira caixa de ferramentas é a que permite manusear os instrumentos necessários para alimentar o raciocínio clínico e outros equipamentos e medicamentos utilizados nas intervenções terapêuticas. São conhecidas como tecnologias duras (MERHY, 2009).

A segunda caixa de ferramentas permite processar o olhar do trabalhador sobre o usuário, valendo-se da somatória dos saberes específicos da clínica, bem como a singularidade do usuário junto às incertezas geradas pela situação em particular. Essa interação profissional-usuário é estabelecida em um território de tensão entre a dureza do pensamento estruturado e a leveza do usuário. O ato clínico pode ser realizado mediante tecnologias duras, voltadas aos processos mais estruturados ou tecnologias leves, com 
predominância dos processos mais permeáveis. Logo, as tecnologias desse território são chamadas tecnologias leve-duras (MERHY, 2009).

A terceira e última caixa é a que permite a produção de relações envolvidas no encontro trabalhador-usuário mediante a escuta, o interesse, a construção de vínculos e a confiança. É a que possibilita captar o universo cultural do usuário e sua singularidade. Nesse território, a ética do trabalho profissional assume papel vital e o usuário encontra maiores possibilidades de interação e espaço para a reflexão. Às tecnologias desse encontro classificam-se como leves (MERHY, 2009).

Nesta perspectiva, os ACS assumem papel de destaque, pelo vínculo com a comunidade e a proximidade das famílias, o qual possibilita a produção de espaços e práticas de cuidado inovadoras. Em sua atuação profissional enfatizam a relevância de tecnologias leves como a construção de estratégias com a equipe; a formação do vínculo, da escuta qualificada e do diálogo como fundamentais ao cuidado integral de mulheres em situação de violência doméstica (HESLER et al., 2013).

A produção dos atos de saúde é constituída pela existência de tecnologias duras, leveduras e leves. No entanto, a centralidade nos problemas específicos e a produção de procedimentos nos serviços de saúde apontam para a predominância da lógica biomédica em detrimento da dimensão cuidadora. Nota-se a necessidade da redefinição dos espaços de relação, priorizando as tecnologias leves e a centralidade do usuário (FEUERWERKER, 2014).

A desvalorização do saber do usuário interfere negativamente na produção do cuidado, diminuindo os benefícios que o saber técnico poderia lhe oferecer. Dessa forma, o encontro entre as partes pode ser marcado por mútua produção ou interdição do outro em função dos saberes legítimos da ciência oficial (FEUERWERKER, 2014).

Muitas vezes, o desencontro entre profissional e usuário é decorrente das diferentes expectativas com relação ao cuidado em saúde. Enquanto o usuário deseja a contribuição do profissional para aliviar seu sofrimento, e não necessariamente uma mudança na organização de sua vida, este último pretende reorganizar a vida dos indivíduos e famílias a luz do conhecimento técnico-científico (FEUERWERKER, 2014).

O ACS por estar familiarizado com os hábitos e costumes da comunidade em que vive e trabalha pode apresentar um olhar mais atento e fidedigno às necessidades dos usuários e usuárias, levando-se em consideração as possibilidades e os limites de sua atuação.

O trabalho das equipes de saúde é fundamental para reorganizar o processo de trabalho e proporcionar uma abordagem integral e resolutiva. A equipe multidisciplinar deve 
ser norteada pelo desenvolvimento de ações coletivas e práticas, as quais visam o saber popular, a autonomia e a potência dos grupos. O cuidado ao usuário deve facilitar a ampliação de redes de conexões existenciais com a produção de mais vida e de um viver mais qualificado (FERREIRA NETO, 2011).

Produzir atos de saúde envolve não apenas os trabalhadores da área, mas também os usuários e seus familiares. Todos podem acolher, escutar, interessar-se, contribuir para a construção de relações de confiança e conforto. Como agente ativo e não meramente objeto das ações de saúde, o usuário desenvolve sua autonomia e empodera-se de suas escolhas, mediante o trabalho conjunto com a equipe (FEUERWERKER, 2014).

$\mathrm{Na}$ busca pelo estabelecimento de laços de confiança, no entanto, não raramente os profissionais de saúde apresentam a tendência à medicalização. As intervenções terminam se constituindo em espaço de afirmações e imposições dos profissionais, reforçando a passividade dos usuários ao invés de sua autonomia (OLIVEIRA et al, 2011).

Assim, somente por meio da integração e do compartilhamento do conhecimento entre os membros da equipe é possível atingir uma mudança estrutural e superar o modelo técnico hierarquizado. A integração dos profissionais de saúde tem como finalidade maior horizontalidade e flexibilidade dos diversos poderes, propiciando a ampliação do grau de autonomia e criatividade entre os envolvidos (CARDOSO e NASCIMENTO, 2010).

Além da integração setorial entre os profissionais da equipe de saúde, há também a participação da sociedade e dos segmentos do poder público. A existência de redes favorece o acesso à informação e à comunicação instantânea. As redes se referem ao conjunto articulado dos serviços e englobam: a assistência policial, jurídica, psicossocial, os serviços de saúde e ainda, ONGs, grupos religiosos e de apoio comunitário, culturais e educativos (SANTOS e VIEIRA, 2011).

A interlocução entre os serviços de prevenção à saúde, saúde mental e os serviços sociais otimizam a efetividade das ações dos casos de violência doméstica contra a mulher, por meio do estabelecimento de vínculos de compromisso e corresponsabilidade (PENHA et al., 2013). A partir do encontro entre profissional-usuário torna-se possível o trabalho vivo em ato e a inovação na produção do cuidado. 


\subsection{EDUCAÇÃO PERMANENTE DO AGENTE COMUNITÁRIO DE SAÚDE: CONSTRUÇÃO DE SIGNIFICADOS E TRANSFORMAÇÃO DAS PRÁTICAS DE TRABALHO}

Segundo ROSA et al. (2010), a dificuldade do profissional de saúde em identificar vítimas de violência no desempenho de suas atividades se deve, prioritariamente, a ele próprio, ao usuário e à formação acadêmica. Esses fatores foram apontados como principais aspectos a contribuir para a invisibilidade da violência. Isso se explica pelo distanciamento entre profissional e usuário, e pela ausência da concepção de integralidade pelo profissional. Quanto ao usuário, justifica-se, pois, que este assume uma postura de omissão quando responsável pela situação de violência ou vergonha, no caso da vítima. Sobre a formação, destaca-se a insuficiência de informação na temática da violência e a superficialidade do tema nas universidades.

Neste sentido, FEUERWERKER (2002) aponta para a complexidade das alterações na formação dos profissionais de saúde, levando-se em consideração mudanças conceituais, de postura e de relações institucionais. Assim, esse processo envolve a desconstrução de conhecimentos, valores e práticas hegemônicas arraigadas e reproduzidas nas estruturas das universidades.

Embora as conquistas no plano jurídico, administrativo e institucional para sustentar o Sistema Único de Saúde sejam inegáveis, as dificuldades dos profissionais para desenvolver as práticas integrais de promoção, prevenção e atenção permanecem, refletindo a necessidade de revisão dos currículos de formação (MINISTÉRIO DA SAÚDE, 2006).

Vale ressaltar, entretanto, que atualmente as Diretrizes Curriculares Nacionais para área de saúde tem valorizado uma abordagem mais social e multiprofissional. Nesta perspectiva, COSTA (1999) afirma ser fundamental a elaboração de currículos pautados no humanismo e em metodologias ativas, pois, propiciam diferentes cenários de aprendizagem com pesquisas integradas ao ensino, participação de profissionais dos serviços e comunidade, bem como a educação orientada para a resolução de problemas e a educação centrada no aluno.

Referente à formação profissional no campo das violências, é imprescindível considerar os aspectos de prevenção, identificação e cuidado às vítimas. Quanto à violência doméstica contra a mulher, sinaliza-se a importância de espaços nas universidades e serviços 
de saúde voltados a reflexão e discussão das relações de gênero. Afinal, a desconstrução dos estereótipos de gênero, marcada pelos preconceitos e discriminação da mulher, é progressiva e necessita ser iniciada nas escolas e no ambiente acadêmico por meio de campanhas, discussões e trabalhos educativos que estimulem a reflexão sobre a formação das representações atribuídas ao feminino e masculino (NÓBREGA e MIRANDA, 2013).

Uma formação socialmente contextualizada, articulada ao mundo de trabalho e ao mundo de ensino é necessária. Espera-se também, o reconhecimento do problema como inerente ao setor saúde para uma aprendizagem adequada e significativa do profissional (COSTA, 1999).

Quanto aos agentes comunitários de saúde aponta-se a importância de sua capacitação para a diminuição dos fatores de risco e reconhecimento das condições de vida da população, sua demanda e prioridades. Dentre as competências a serem desenvolvidas por este profissional destacam-se as noções de causa, consequência e prevenção, além da observação minuciosa, comunicação clara e objetiva, integração, liderança, responsabilidade e autonomia (TOMAS, 2002).

Devido às inúmeras atribuições voltadas a este profissional e a intensa carga horária de trabalho em contato direto com a comunidade, os ACS encontram-se mais vulneráveis ao desenvolvimento da Síndrome do Esgotamento Profissional (Síndrome de Burnout) e de Transtornos Mentais Comuns (TMC) (SILVA e MENEZES, 2008).

Estudo realizado com agentes comunitários e técnicos de enfermagem no município do Rio Grande/RS, com o intuito de analisar as representações sociais acerca da violência doméstica contra a mulher, por meio da técnica de evocação livre e entrevista em profundidade, aponta para o surgimento de intensos sentimentos de medo, raiva, revolta, tristeza e humilhação destes profissionais ao evidenciarem situações de violência doméstica contra a mulher (SILVA et al., 2015b).

As práticas destes profissionais são influenciadas tanto pelos recursos internos como pelos recursos externos que dispõem. Por recursos internos, entende-se a capacidade do indivíduo em lidar com a própria frustração, discernir e agir com assertividade. Por recursos externos, refere-se às redes de apoio, a equipe multidisciplinar, o Núcleo de Apoio a Saúde da Família (NASF) e os demais serviços disponíveis na comunidade que contribuam para a promoção em saúde.

Pela aproximação das famílias e conhecimento das demandas, muitas vezes, sentimentos ambíguos, que oscilam da onipotência à frustração são despertados. Os problemas e as vulnerabilidades das famílias, somados à inexistência de limites entre o 
ambiente de trabalho e moradia são responsáveis pelo esgotamento físico e mental deste profissional (LUNARDELO, 2004).

De acordo com AKERMAN et al. (2012), na pesquisa "Dissonâncias entre as competências ofertadas pelos agentes comunitários de saúde e as expectativas da população", 96\% dos ACS consideram-se preparados para a atuação com a comunidade e a unidade de saúde, muito embora "problemas administrativos" e "tristeza por não fazer algo pelo morador" tenham sido citados como fatores desmotivadores.

Dentre as competências que devem ser exercidas pelos ACS, cabe a estes profissionais "estimular indivíduos, famílias e grupos a participarem de programas sociais locais que envolvam orientação e prevenção da violência intra e interfamiliar”. No entanto, a pesquisa "Dissonâncias entre as competências ofertadas pelos agentes comunitários de saúde e as expectativas da população" aponta que esta competência é menos realizada que outras. Considera-se a violência um fator limitante para a atuação do agente, que reside na própria comunidade (AKERMAN et al., 2012).

Nestas condições, destaca-se a necessidade de espaços de acolhimento e capacitação do ACS direcionada para a área da violência doméstica contra a mulher, diante da qual sistematicamente se depara no exercício de sua prática profissional, repetindo recomendações biomédicas sem um esforço de contextualização ou reflexão (NUNES et al., 2002).

As normas e diretrizes do Programa de Agentes Comunitários de Saúde, com a publicação da Portaria n. 1886, estabelece com relação à capacitação dos ACS:

[...] 8.7 A capacitação do Agente Comunitário de Saúde deve ocorrer em serviço, de forma continuada, gradual e permanente, sob a responsabilidade do InstrutorSupervisor, com a participação e colaboração de outros profissionais do serviço local de saúde [...].

[...] 8.9 O conteúdo das capacitações deve considerar as prioridades definidas pelo elenco de problemas identificados em cada território (BRASIL, 1997, p. 11).

No artigo 30, da Lei n.10.507 de julho de 2002, que regulamenta a profissão de agente comunitário de saúde, afirma que este profissional deve residir na área da comunidade em que atua, ter finalizado com aproveitamento o curso de qualificação básica e haver concluído o ensino fundamental (BRASIL, 2002).

Considerando a Lei de Diretrizes e Bases (LDB), n. 9.394, a qual propunha as Diretrizes Curriculares Nacionais para a Educação Profissional de Nível Técnico, o Ministério da Saúde, em 2003, aprovou a Política de Formação e Desenvolvimento para o SUS: caminhos para a Educação Permanente em Saúde (MINISTÉRIO DA SAÚDE, 2003). 
Em 2004, pela portaria n.198, foi estabelecida a Política Nacional de Educação Permanente em Saúde (PNEPS) e em 2007, pela portaria de n.1996, essa política foi implementada com novas diretrizes e estratégias, adotando como eixo estruturante a valorização do trabalho e dos trabalhadores (MINISTÉRIO DA SAÚDE, 2007).

A Educação Permanente em Saúde, inspirada no ideário freireano, considera as múltiplas possibilidades de aprendizagem significativa recorrentes do processo de trabalho. Mediante a reflexão crítica e a problematização das práticas dos serviços de saúde, propõe que o conhecimento seja construído a partir das experiências dos trabalhadores e da realidade local (MINISTÉRIO DA SAÚDE, 2004a).

Logo, com a problematização da realidade, torna-se possível a desconstrução do modelo hegemônico em saúde. O sentimento de incômodo advindo da reflexão crítica desperta o desejo de mudança no profissional, possibilitando a construção de novas estratégias para a produção de saúde (ROSCHKE, 2006).

Referente à formação profissional do ACS, o Departamento de Gestão da Educação na Saúde (DEGES) contribuiu para a construção do Referencial Curricular para o Curso Técnico de Agente Comunitário de Saúde, que tem como objetivo:

[...] preparar profissionais para atuar como técnicos de nível médio junto às equipes multiprofissionais que desenvolvem ações de cuidado e proteção à saúde de indivíduos e grupos sociais, em domicílios e coletividades, estruturados com uma carga horária mínima de 1200 horas, distribuídas em três etapas formativas (MINISTÉRIO DA SAÚDE, 2004b, p.16).

Dentre as competências que compõem o atual perfil do ACS espera-se que este profissional busque a integração da equipe de saúde com a população, sendo capaz de avaliar e planejar ações de saúde com a equipe, visando à melhoria da qualidade de vida da comunidade. Além disso, deseja-se que o ACS desenvolva ações de prevenção e monitoramento de risco ambiental e sanitário, assim como de prevenção e monitoramento a grupos específicos e morbidades (MINISTÉRIO DA SAÚDE, 2004b).

Diante de problemas sociais complexos, como a violência contra a mulher, cabe ao ACS dialogar, orientar quanto aos serviços disponíveis em rede e dar suporte. Como afirma VASCONCELOS (1998), alguns problemas são muito profundos para serem “curados", mas não para serem "cuidados".

Dessa forma, enfatiza-se o processo de educação permanente do ACS, que na maioria das vezes, não foi devidamente sensibilizado, capacitado e reconhecido em suas potencialidades para trabalhar com temáticas tão complexas como a violência doméstica contra a mulher (BERGER et al., 2014). 


\section{PRESSUPOSTO}

- As representações sociais do agente comunitário de saúde sobre a violência doméstica contra a mulher interferem na identificação dos casos e práticas deste profissional. 


\section{OBJETIVOS}

\subsection{OBJETIVO GERAL}

- Conhecer e problematizar as representações do ACS sobre a violência doméstica contra a mulher.

\subsection{OBJETIVOS ESPECÍFICOS}

- Entender como as representações sobre a violência doméstica contra a mulher interferem na identificação dos casos e práticas do ACS;

- Descrever as práticas do ACS ao lidar com situação de violência doméstica contra a mulher;

- Relacionar as práticas do ACS e suas representações sobre a violência doméstica contra a mulher. 


\section{PERCURSO METODOLÓGICO}

\subsection{TIPO DO ESTUDO}

Tendo em vista a natureza do problema de investigação, optou-se por desenvolver uma pesquisa de abordagem qualitativa, uma vez que importa conhecer o universo dos significados, das representações, crenças, percepções e opiniões dos agentes comunitários de saúde. Foram desenvolvidos grupos focais com esta categoria profissional, com enfoque nas representações sociais e práticas dos ACS em situação de violência doméstica contra a mulher.

A pesquisa qualitativa parte do pressuposto de que o mundo torna-se real à medida que faz sentido para o sujeito (VÍCTORA et al., 2000). É relevante ao estudo das relações sociais e redimensiona como também sensibiliza novos contextos e perspectivas sociais, exigindo do pesquisador maior familiaridade com a pluralização das esferas de vida (FLICK, 2009).

Os grupos focais funcionam como entrevistas em grupo, que valorizam a comunicação entre os participantes a fim de gerar dados distintos. São utilizados em diferentes contextos e visam explorar a compreensão do público sobre determinada temática, suas experiências e atitudes. Este método estimula as diversas formas de comunicação dos participantes, por meio de perguntas abertas, que permitem ao grupo identificar normas e valores culturais. Além de favorecer a expressão de críticas e facilitar a comunicação de ideias e experiências que poderiam ser pouco desenvolvidas em uma entrevista frente a frente (POPE e MAYS, 2009).

Nesta perspectiva, os grupos focais possibilitam a discussão de tópicos complexos, contribuindo na visão da pesquisadora para o debate com os agentes comunitários de saúde sobre a violência doméstica contra a mulher. Assim, mediante a interação gerada pelos participantes menos inibidos, os participantes mais tímidos são envolvidos na discussão e estimulados a exporem sua opinião. Logo, a variedade de comunicação e sinergismo grupal propicia maior conhecimento das atitudes dos envolvidos (POPE e MAYS, 2009). 


\subsection{O CENÁRIO DO ESTUDO}

O município de Jundiaí está localizado entre as cidades de São Paulo e Campinas, cuja área física corresponde a 431,97 $\mathrm{km}^{2}$. Tem como municípios limítrofes: Vinhedo, Itatiba e Louveira ao norte, Campo Limpo Paulista, Jarinu e Várzea Paulista ao leste, Cabreúva e Itupeva ao oeste e Cajamar, Franco da Rocha e Pira Pora de Bom Jesus ao sul (PREFEITURA DE JUNDIAÍ, 2016a).

O crescimento da cidade de Jundiaí ocorreu na metade do século XIX com a produção do café, que estimulou a construção da Ferrovia Santos-Jundiaí em 1867 e a instalação de indústrias. A cidade tornou-se estratégica no setor ferroviário, e os grandes produtores rurais passaram a buscar novos trabalhadores, dando início ao processo de imigração (PREFEITURA DE JUNDIAÍ, 2016b).

O processo de industrialização da cidade concentrava-se nos segmentos têxtil e cerâmico. Com a construção da Rodovia Anhanguera, houve um novo impulso industrial, atraindo outras indústrias como as metalúrgicas, e possibilitando a abertura ao capital estrangeiro em 1950 (PREFEITURA DE JUNDIAÍ, 2016b).

Atualmente a população do município é composta por 397.765 habitantes, sendo $75 \%$ do total descendente de imigrantes italianos, compondo uma das maiores colônias do Brasil. A cidade destaca-se por sua vocação industrial e apresenta um dos maiores parques industriais da América Latina (PREFEITURA DE JUNDIAÍ, 2016a).

A cidade vem se desenvolvendo e ampliando nas áreas cultural, educacional, tecnológica e ambiental. A indústria do lazer também se sobressai pela instalação de parques temáticos que atraem turistas e geram empregos (PREFEITURA DE JUNDIAÍ, 2016a).

O Índice de Desenvolvimento Humano Municipal (IDHM) de Jundiaí no ano 2000 correspondia a 0,857, em contrapartida o IDHM do Estado de São Paulo e do Brasil equivalia a 0,814 e 0,769 respectivamente. O IDHM de Jundiaí ocupa a $14^{\circ}$ posição no Brasil entre 5.507 municípios, a $4^{\circ}$ posição no estado de São Paulo entre 645 municípios e a $2^{\circ}$ posição no estado de São Paulo dos municípios com mais de 200.000 habitantes (PREFEITURA DE JUNDIAÍ, 2016a).

Os serviços de Atenção Básica $(\mathrm{AB})$ da rede de atendimento a saúde são compostos por 36 Unidades Básicas de Saúde (UBS), sendo 5 delas Unidades Básicas de Saúde da Família (UBSF), conforme apresentadas na Figura 1 abaixo, a saber: Unidade de Saúde da 
Família Vila Marlene, Unidade de Saúde da Família Parque Centenário, Unidade de Saúde da Família Santa Gertrudes, Unidade de Saúde da Família Vila Esperança e Unidade de Saúde da Família Vila Ana.

Figura 1 - Mapa ilustrativo das Unidades de Saúde da Família do município de Jundiaí

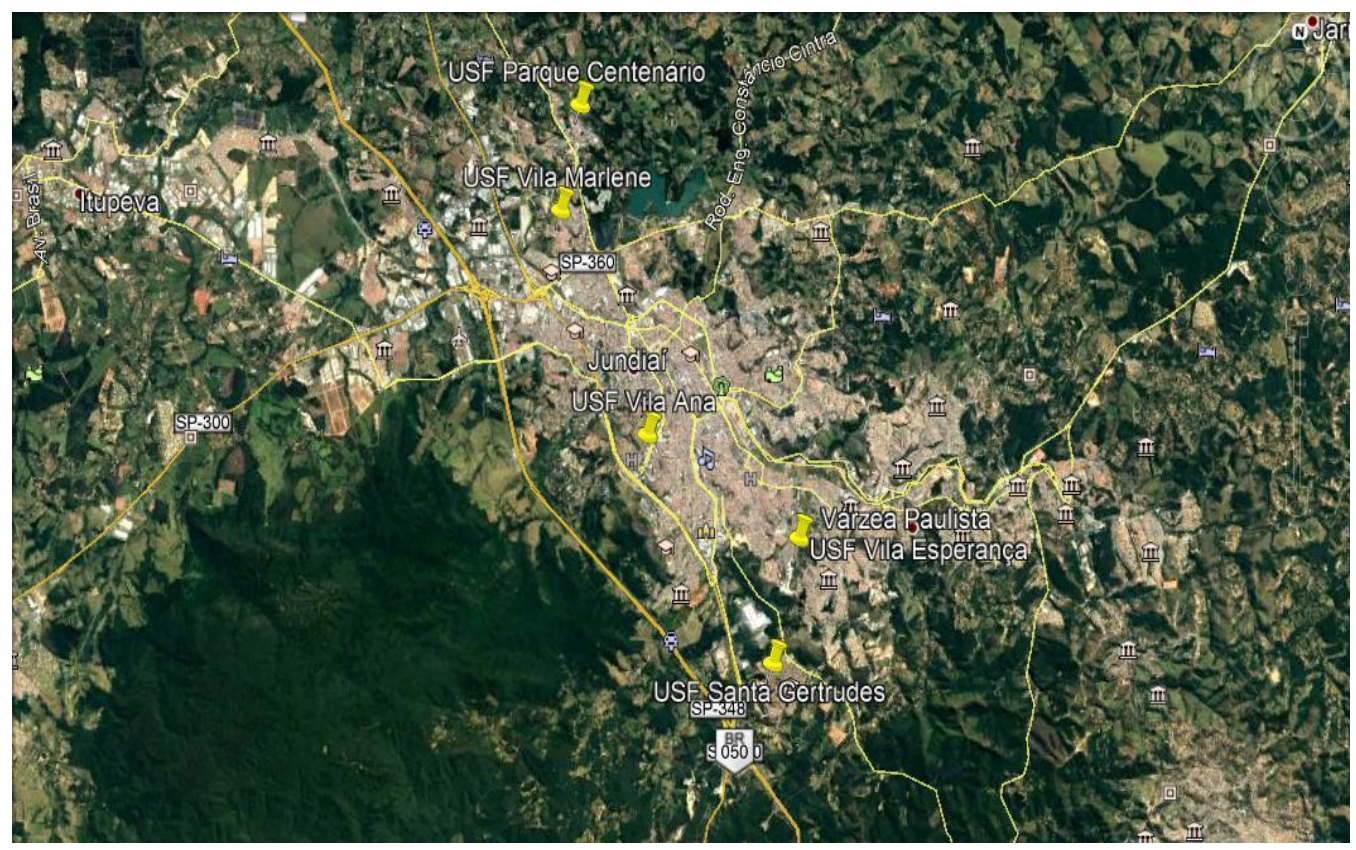

Fonte: Google Earth (2018)

A rede de atenção básica à saúde conta também com o Centro de Convivência Cultura, Trabalho e Geração de Renda (CECCO); o Centro de Testagem e Acolhimento (CTA) e a Academia de Saúde (PREFEITURA DE JUNDIAÍ, 2017c).

Os serviços da Atenção Especializada são compostos pelos serviços de saúde mental com o Centro de Atendimento Psicossocial - Adulto (CAPS II e III), com o Centro de Atendimento Psicossocial Infantil (CAPSi II), com o Centro de Atendimento Psicossocial Álcool e Drogas (CAPS Ad III) e pelo Consultório de Rua. Contempla o Ambulatório de Saúde Mental, o Ambulatório de Saúde da Mulher, o Núcleo Integrado de Saúde (NIS), o Núcleo de Assistência ao Portador de Deficiência Física (NAPD), o Centro de Referência do Idoso de Jundiaí (CRIJU), o Centro de Especialidade de Odontologia (CEO) e o Centro Especializado no Tratamento de Dependências de Álcool e Drogas (CEAD) (PREFEITURA DE JUNDIAÍ, 2017c). 
Em relação à Assistência Hospitalar de Urgência e Emergência, a mesma é composta por quatro unidades de Pronto-Atendimento (PA), pelo Pronto-Socorro (PS) do Hospital Universitário (HU) e do Hospital São Vicente de Paulo, pelo Banco de Leite Humano, pelo Serviço de Atendimento a Pacientes Especiais e Crônicos (SAEC) e pelo Serviço de Atendimento Móvel de Urgência (SAMU) (PREFEITURA DE JUNDIAÍ, 2017c).

A Vigilância em Saúde é composta pela Vigilância Epidemiológica (VE), pela Vigilância Sanitária (VISA), pelo Centro de Referência em Saúde do Trabalhador (CEREST) e pela Vigilância em Saúde do Trabalhador (VISAT) (PREFEITURA DE JUNDIAÍ, 2017c).

Figura 2 - Rede de Atenção à Saúde

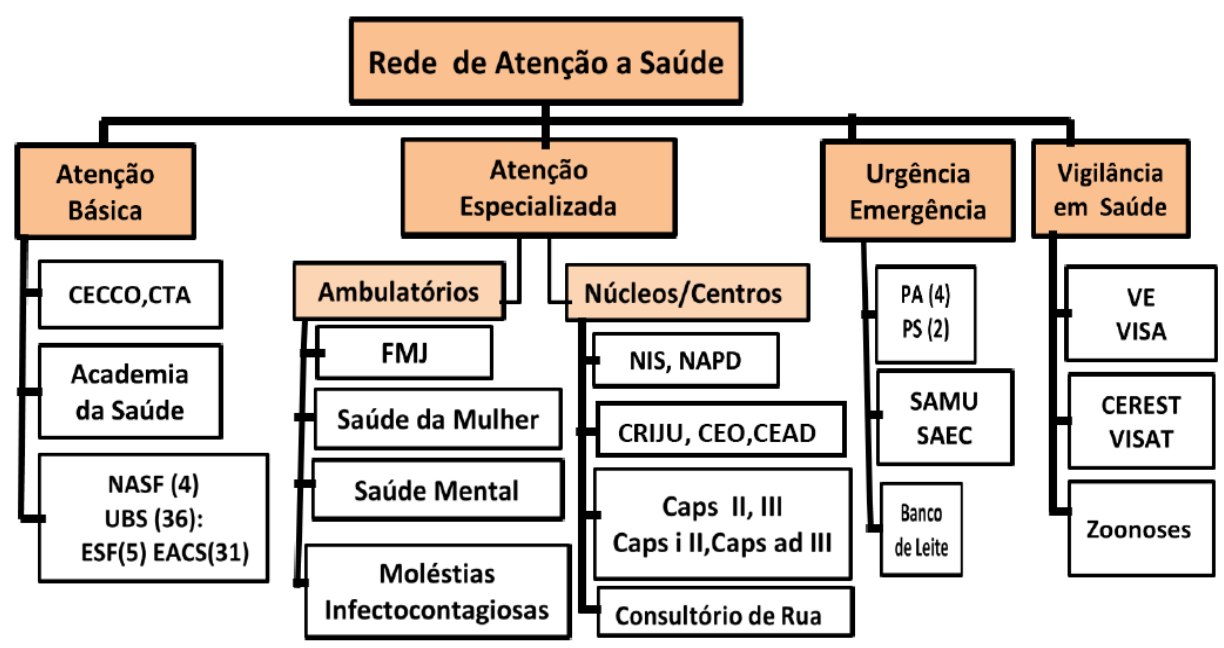

Em relação ao Departamento de Proteção Social Básica, são oferecidos serviços ao usuário pelo Centro de Referência de Assistência Social (CRAS), pelo Centro de Convivência do Idoso e Serviço de Atendimento Social (SAS). Atualmente o Município é composto por cinco CRAS. Conta também com os serviços de três Conselhos Tutelares (PREFEITURA DE JUNDIAÍ, 2017d).

O Departamento de Proteção Social Especial do Município, na média complexidade, conta com o Centro de Referência Especializado de Assistência Social (CREAS), dois Centros de Referência Especializado de Assistência Social para População de Rua (CREAS POP), o condomínio do Idoso e o Serviço Especializado em Abordagem (SEA). Na alta complexidade, oferece o Serviço de Acolhimento Institucional, o Serviço de Acolhimento em 
República, o Serviço de Acolhimento em Família Acolhedora, o Serviço de Proteção em situações de Calamidade Pública e de Emergência (PREFEITURA DE JUNDIAÍ, 2017d).

Figura 3 - Rede de Proteção Social

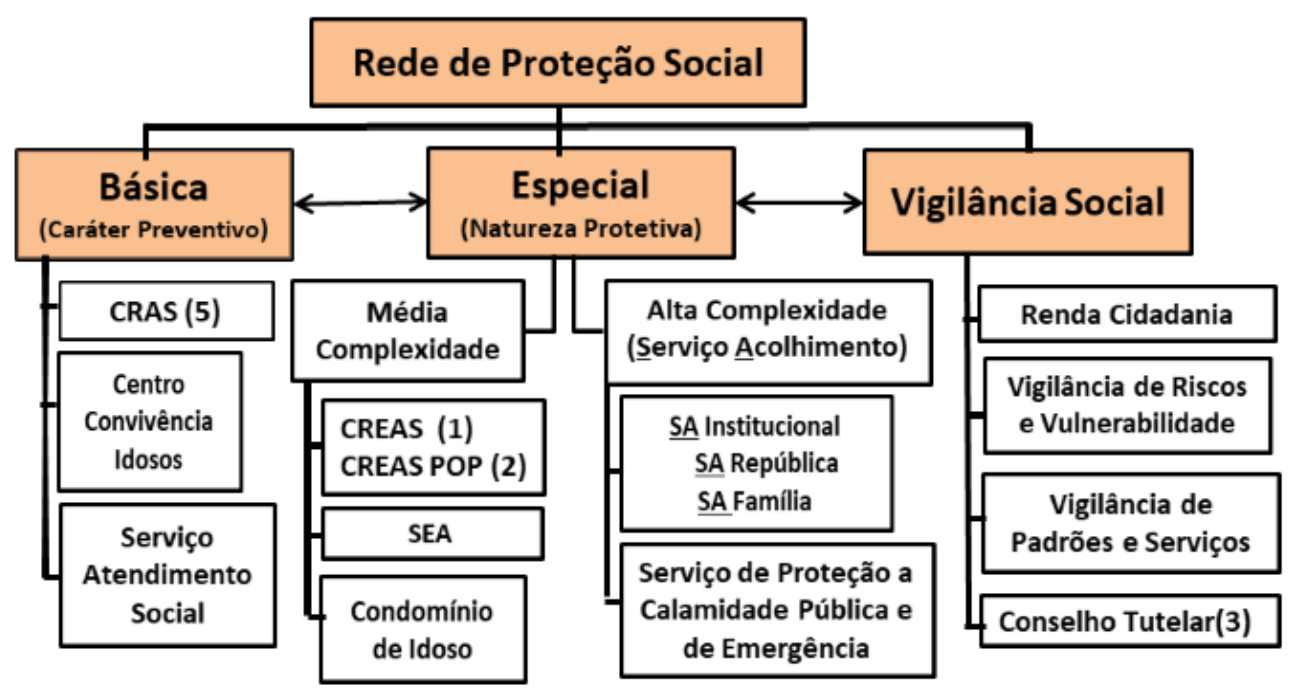

Referente à Segurança e Proteção do cidadão, esta é composta pelos seguintes serviços: a Delegacia Seccional de Polícia, seis Distritos Policiais, a Delegacia de Defesa da Mulher, a Delegacia de Investigação sobre Entorpecentes (DISE) e a Guarda Municipal (PREFEITURA DE JUNDIAÍ, 2017d).

Figura 4 - Serviços de Segurança e Proteção do Cidadão

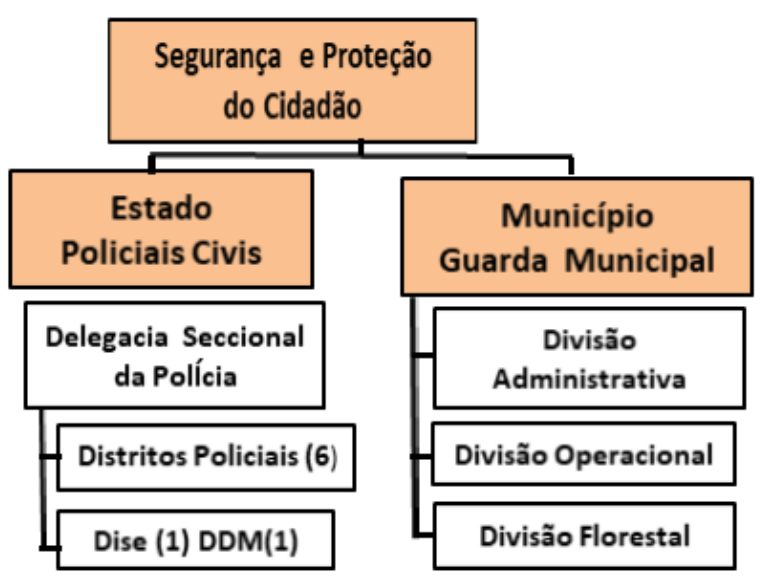




\subsection{SUJEITOS DA PESQUISA}

Participaram do estudo os ACS que atuam nas cinco equipes de ESF do município de Jundiaí. Sendo uma de suas atribuições a identificação de fatores de risco na comunidade, acredito que as representações sociais do ACS sobre a violência doméstica contra a mulher interfiram na identificação dos casos e práticas deste profissional.

Segundo MINAYO (2008, p.219), as representações sociais correspondem a "categorias de pensamento, ação e sentimento que expressam a realidade". Constituem a reprodução de uma percepção anterior, como parte da construção do real. Para VÍCTORA et al. (2000), as representações sociais funcionam, não meramente como abstrações, mas como orientadoras das práticas sociais. Logo, consideramos o estudo das representações sociais deste profissional fundamental para a compreensão de suas práticas ao lidar com situações de violência doméstica contra a mulher.

\subsection{CARACTERIZAÇÃO DOS PARTICIPANTES DA PESQUISA}

Dos vinte seis agentes comunitários de saúde participantes das entrevistas em grupo, apenas dois eram do sexo masculino. As idades dos ACS variaram entre 26 a 69 anos e o tempo de atuação na profissão entre 2 anos e meio a 14 anos. No total, são quinze agentes de saúde casados, quatro solteiros, três viúvos, dois separados e dois em união estável, que apresentam de 0 a 3 filhos. Quanto ao grau de escolaridade, vinte agentes comunitários possuem $2^{\circ}$ grau completo, dois possuem $2^{\circ}$ grau incompleto, três apresentam superior completo e um dos ACS superior incompleto. A grande maioria dos agentes comunitários se declarou de cor branca, um deles de cor preta, um pardo e um dos ACS não assinalou nenhuma das opções.

\subsection{OS INSTRUMENTOS DE COLETA}


Foram utilizados os seguintes procedimentos metodológicos, a fim de compreender com maior precisão a realidade de mulheres em situação de violência e as representações dos ACS: o grupo focal, que será explicado mais adiante em "as fases da pesquisa", e um caderno de campo, no qual foram registradas as impressões da pesquisadora sobre os profissionais de saúde e a dinâmica da equipe. Além de informações sobre os serviços prestados nas UBSF e na rede de assistência.

As observações da pesquisadora em seu caderno de campo foram feitas para melhor compreensão deste cenário, mediante as conversas com os profissionais da rede de assistência, sua participação nas reuniões de equipe, reuniões de matriciamento, encontros com ACS e outras atividades propostas pelas UBSF.

\subsection{ASPECTOS ÉTICOS}

Para atender aos requisitos éticos, foi enviado à Coordenadora da Estratégia de Saúde da Família (ESF) um pedido de autorização para a realização do estudo. De acordo com as normas estabelecidas pela Resolução 466/2012 do Conselho Nacional de Saúde, o projeto foi enviado ao Comitê de Ética em Pesquisa da Faculdade de Saúde Pública pela Plataforma Brasil. Foi aprovado nas duas instâncias em 16 de abril de 2016 pela Coordenadora da Estratégia de Saúde da Família e 21 de setembro de 2016 pelo Comitê de Ética em Pesquisa da FSP sob o $n^{\circ}$ CAAE 56525916400005421.

\subsection{AS FASES DA PESQUISA}

A primeira fase da pesquisa foi desenvolvida com o objetivo de conhecer as UBSF, fazer uma aproximação do campo e dos profissionais, participar das reuniões de equipe e matriciamento e das demais atividades desenvolvidas nas UBSF, como por exemplo, atividades recreativas voltadas à comunidade, reuniões de ACS, encontros entre a pesquisadora e os ACS para conhecimento da rotina e expectativa desses profissionais quanto aos serviços e acompanhamento de ACS em visita domiciliar. 
O contato inicial foi feito com os gerentes das unidades por e-mail e telefone. Uma primeira conversa foi agendada com cada gerente para explicar o projeto e as etapas da pesquisa que se realizariam nas unidades. Os objetivos do estudo foram apresentados, buscando-se sensibilizar os gestores sobre a importância da proposta de pesquisa, como também o apoio necessário para seu desenvolvimento. A princípio, foi estabelecido um primeiro contato com os ACS por meio das reuniões de equipe, nas quais a pesquisadora pode se apresentar.

O estudo foi realizado nas cinco UBSF do Município entre os meses de maio a agosto de 2016. Com o suporte e apoio da gerência foi possível participar não apenas das reuniões de equipe e atividades previstas com os agentes comunitários, mas de todas as atividades desenvolvidas nas UBSF. Essa aproximação do campo e contato com os ACS e demais profissionais contribuiu para a adesão, posteriormente, à proposta metodológica dos grupos focais.

A segunda fase da pesquisa teve como objetivo o desenvolvimento dos grupos focais. Realizou-se um grupo em cada UBSF, de 80-120 minutos cada um deles, totalizando cinco grupos. Todos os ACS foram convidados a participar, independente da idade, sexo ou tempo de atuação no cargo. Dois moderadores conduziram o grupo. A pesquisadora foi uma das moderadoras e ficou responsável por mediar a discussão entre os participantes e facilitar a dinâmica grupal. A segunda moderadora, enfermeira de formação e experiente em ESF, ficou responsável pelas observações (Apêndice 4), destacando-se a dinâmica grupal, a linguagem corporal e comentários relevantes do grupo, além dos aspectos técnicos referentes à distribuição do TCLE e da ficha de perfil, do manuseio do gravador e também, do cuidado com o lanche e possíveis interrupções.

Foi realizado um pré-teste do roteiro de questões com a finalidade de antecipar a discussão e as possíveis manobras conversacionais. Posteriormente, realizou-se um pré-teste de grupo focal com o intuito de avaliar a efetividade das estratégias de condução do grupo. No início dos encontros houve um quebra-gelo, em que a pesquisadora se apresentava, explicava os objetivos da pesquisa, entregava o TCLE (Apêndice 1) e a ficha de perfil do agente comunitário de saúde (Apêndice 2). Ainda no quebra-gelo, a pesquisadora fazia uma rodada de apresentações com os ACS e na sequência, introduzia a discussão com uma charge (Apêndice 3) relacionada a primeira pergunta disparadora. Os encontros foram gravados e transcritos.

No total, 26 ACS participaram da pesquisa. Vale ressaltar que as UBSF não estavam com seu quadro completo de ACS. Todas elas apresentavam ausência de um profissional. A 
UBSF Santa Gertrudes, composta por duas equipes de ACS, estava com um quadro de apenas 9 profissionais, dois profissionais em falta e um profissional afastado.

\subsubsection{Os Grupos Focais}

Os grupos focais foram realizados no período de julho a agosto de 2016. Utilizaram-se as salas de atendimento das próprias unidades, com exceção das UBSF Vila Esperança e Santa Gertrudes, que tiveram a realização dos grupos nas capelas próximas.

A adesão da gerência ao estudo proposto contribuiu para a vinculação com os ACS. Os grupos focais foram agendados com os gerentes das unidades em acordo com os ACS. Houve apoio e suporte, embora, a princípio, certa resistência e desconfiança de alguns gerentes. Com exceção da UBSF Santa Gertrudes, na qual três dos ACS não participaram da pesquisa, todos os ACS das demais unidades aceitaram o convite. Acredita-se que a ausência da gerência e de uma infraestrutura própria para a UBSF Santa Gertrudes, que atualmente divide o mesmo espaço com a UBS tradicional ${ }^{2}$ do bairro tenha interferido na vinculação com esses ACS.

Nesses encontros, inicialmente eram apresentados os objetivos do estudo e na sequência eram distribuídos pela observadora uma ficha de perfil do ACS (Apêndice 2) e duas vias do TCLE (Apêndice 1) assinadas pela pesquisadora. Uma dessas vias permanecia com o ACS e a outra era recolhida, assim como a ficha de perfil.

A realização dos grupos focais foi satisfatória, com poucas interrupções e interferências no decorrer do processo. Apenas alguns ruídos, em virtude de uma infraestrutura pouco favorável. E também pelo desencontro de informação entre gerente e ACS quanto ao início do horário do grupo em uma das unidades.

Entende-se por grupo focal uma discussão focalizada, na qual o pesquisador reúne no mesmo local, durante um período de tempo, uma quantidade de pessoas que fazem parte do objeto de suas investigações. Tem como objetivo coletar as informações sobre um tema

\footnotetext{
2 A UBS tradicional apresenta equipes formadas por médicos (clínicos, pediatras e obstetras), enfermeiros, dentistas, auxiliares de enfermagem e pessoal de apoio técnico. Há também a presença de médicos de diversas especialidades, distribuídos irregularmente pelas unidades. A demanda atendida se apresenta como espontânea e/ou encaminhada por outros serviços. Neste caso não há adstrição de clientela, e a delimitação da área de abrangência se refere exclusivamente às ações de vigilância à saúde. As unidades de PSF contam com Equipes de Saúde da Família (ESF) em conformidade com as normas do MS e também obedecem ao preceito da delimitação de área de abrangência com adstrição de clientela (ELIAS PE et. al., 2006).
} 
específico, por meio do diálogo e debate entre os participantes, para alcançar resultados qualitativos em profundidade (CRUZ NETO et. al., 2002).

A técnica de grupo focal permite a participação e a apresentação das concepções dos participantes. Trata-se de uma "fala" em debate, não meramente descritiva ou expositiva, mas que favorece a interação, o diálogo e a troca de ideias, que por sua vez, possibilitam uma compreensão mais refinada sobre a temática abordada (CRUZ NETO et. al., 2002).

O roteiro de debate (Apêndice 3) foi organizado pela própria pesquisadora. E a escolha da técnica de grupo focal teve como objetivo não apenas coletar os dados em um curto período de tempo, mas principalmente valorizar a interação entre os participantes e a mediadora, captando por meio da discussão e reflexão da temática, o maior número de representações dos ACS.

\subsection{ANÁLISE DOS DADOS}

As transcrições das entrevistas em grupo possibilitaram à pesquisadora o aprofundamento da coleta dos dados, o que demandou grande investimento de tempo. As falas foram transcritas na íntegra e as gravações foram conservadas, com o intuito de apreender com maior precisão os discursos dos profissionais e a situação emocional em que os sujeitos se encontravam. Os grupos focais foram identificados de acordo com a ordem cronológica de sua realização como GF1, GF2, e assim por diante até GF5. Os agentes comunitários, de igual modo, foram identificados como ACS 1, ACS 2, e assim por diante até ACS 26.

A análise dos dados tem a finalidade de ordenar as informações coletadas, objetivando a formulação de considerações gerais. Esse processo envolve a organização e sintetização dos dados qualitativos para a compreensão de seu significado (POLIT e BECK, 2011).

Para a análise do material empírico resultante da transcrição das entrevistas em grupo foi utilizada a Análise Temática de Conteúdo (ATC) proposta por Bardin. Os dados foram agrupados por temas, e o pesquisador examinou os núcleos de sentido minuciosamente para garantir que todas as manifestações fossem incluídas e comparadas. A pesquisa teve como objetivo descrever estes agrupamentos temáticos e posteriormente buscou relacioná-los (POPE e MAYS, 2009). 
Segundo BARDIN (2009), o tema é uma unidade de significação que serve de guia a leitura. Comporta um feixe de relações e pode ser graficamente apresentado através de uma palavra, de uma frase, de um resumo.

A técnica de análise temática desdobra-se em três etapas: 1) pré-análise, 2) exploração do material, 3) tratamento dos dados obtidos e interpretação. Durante a fase de pré-análise, foram realizadas leituras exaustivas das transcrições, buscando-se confrontar o conteúdo dessas entrevistas grupais com os objetivos do estudo, processo denominado "leitura flutuante". Nessa fase, o texto foi recortado e numerado em unidades de registro ou unidades de significado que podem se apresentar sob a forma de uma única palavra, frase ou parágrafo e constituem o processo de codificação ou transformação dos dados brutos do texto. A segunda etapa consistiu na exploração do material, em que os discursos foram categorizados por meio de expressões ou palavras significativas para alcançar o núcleo de compreensão do texto. A terceira etapa consistiu na interpretação dos conteúdos manifestos e latentes contidos em todo o material coletado. A análise foi feita pela justaposição das diversas categorias existentes, ressaltando os aspectos semelhantes e divergentes.

As categorias foram criadas levando-se em consideração os objetivos do estudo, a organização dos comentários dos agentes comunitários por temas, a verificação minuciosa dos núcleos de sentido e por último, a classificação e o agrupamento das unidades de registro, o que permitiu a construção de duas categorias e sete subcategorias de análise. A primeira categoria "Representações dos agentes comunitários de saúde sobre violência contra a mulher" apresentou cinco subcategorias: "Concepções dos agentes comunitários de saúde sobre mulheres em situação de violência", "Fatores que contribuem para desencadear ou reforçar situações de violência contra a mulher", "O olhar dos agentes comunitários sobre as justificativas da mulher para a permanência em situação de violência", "Modos pelos quais as mulheres enfrentam a situação de violência no relato dos agentes comunitários", "Legislação". A segunda categoria "Atenção à violência nos serviços de saúde e na rede de assistência" apresentou as seguintes subcategorias: "Representações dos agentes comunitários sobre os serviços de saúde", "Práticas dos agentes comunitários de saúde a mulheres em situação de violência". 


\section{RESULTADOS E DISCUSSÃO}

A partir do exposto anteriormente no procedimento de análise, nesta etapa serão apresentados os resultados obtidos nas categorias e subcategorias demonstradas no quadro 1 abaixo:

Quadro 1 - Categorias de Análise.

\begin{tabular}{|c|c|c|}
\hline Categorias Gerais & Categorias Intermediárias & Categorias Específicas \\
\hline $\begin{array}{l}6.1 \text { Representações dos } \\
\text { agentes comunitários de } \\
\text { saúde sobre violência } \\
\text { contra a mulher }\end{array}$ & $\begin{array}{llr}6.1 .1 & \text { Concepções } & \text { dos } \\
\text { agentes comunitários } & \text { de } \\
\text { saúde sobre mulheres } & \text { em } \\
\text { situação de violência } & \end{array}$ & $\begin{array}{l}\text { 6.1.1.1 Fatores que contribuem } \\
\text { para desencadear ou reforçar } \\
\text { situações de violência contra a } \\
\text { mulher } \\
6.1 .1 .2 \text { O olhar dos agentes } \\
\text { comunitários sobre as } \\
\text { justificativas da mulher para a } \\
\text { permanência em situação de } \\
\text { violência } \\
\text { 6.1.1.3 Modos pelos quais as } \\
\text { mulheres enfrentam a situação } \\
\text { de violência no relato dos } \\
\text { agentes comunitários } \\
\text { 6.1.1.4 Legislação }\end{array}$ \\
\hline $\begin{array}{l}6.2 \text { Atenção à violência nos } \\
\text { serviços de saúde e na rede } \\
\text { de assistência }\end{array}$ & $\begin{array}{l}\text { 6.2.1 Representações dos } \\
\text { agentes comunitários sobre } \\
\text { os serviços de saúde }\end{array}$ & $\begin{array}{l}\text { 6.2.1.1 Práticas dos agentes } \\
\text { comunitários de saúde a } \\
\text { mulheres em situação de } \\
\text { violência }\end{array}$ \\
\hline
\end{tabular}

Fonte: A pesquisadora (2018)

Para apoiar e problematizar a discussão serão utilizadas as observações de campo da pesquisadora e as conversas com os profissionais da rede de assistência, dentre eles: os gerentes das Unidades de Saúde da Família (5), profissionais da equipe de ESF (6), profissionais do NASF (2), profissionais de Segurança Pública (3), o coordenador do Consultório de Rua, a psicóloga do Ambulatório de Saúde da Mulher, a psicóloga do abrigo "Casa Sol”, a enfermeira da Vigilância Epidemiológica e a assessora de políticas para as mulheres. 


\subsection{REPRESENTAÇÕES DOS AGENTES COMUNITÁRIOS DE SAÚDE SOBRE VIOLÊNCIA CONTRA A MULHER}

As representações sociais de uma coletividade ou grupo se referem a um modo particular de compreender e de se comunicar, um modo que cria tanto a realidade como o senso comum. Essas representações apresentam caráter dinâmico e funcionam como uma "rede de ideias, metáforas e imagens" influenciadas pela cultura, ideologias e teorias, sendo compartilhadas por todos e reforçada pela tradição (MOSCOVICI, 2007, p. 210).

MOSCOVICI (2007) explica que a influência das representações se faz presente tanto no pensamento como no comportamento do indivíduo. Por meio delas, o indivíduo abstrai sentido e significa o mundo de forma a introduzir nele ordem e percepções. Neste sentido, afirma:

\footnotetext{
"Nenhuma mente está livre dos efeitos de condicionamentos anteriores que lhe são impostos por suas representações, linguagem ou cultura. Nós pensamos através de uma linguagem; nós organizamos nossos pensamentos, de acordo com um sistema que está condicionado, tanto por nossas representações como por nossa cultura" (MOSCOVICI, 2007, p. 35).
}

Deste modo, as representações não são criadas por um indivíduo isoladamente, contudo, uma vez criadas, elas adquirem vida própria, contribuem para o nascimento de novas representações e transformam a realidade compartilhada. Para compreender e explicar uma representação, no entanto, torna-se necessário começar com aquela da qual se originou (MOSCOVICI, 2007).

Com o intuito de compreender as representações dos agentes comunitários a respeito da violência doméstica contra a mulher e suas práticas é imprescindível considerar os aspectos culturais relacionados às questões de gênero, bem como a realidade compartilhada na comunidade, no ambiente de trabalho e na experiência profissional.

De acordo com as agentes comunitárias ${ }^{3}$ a violência contra a mulher não é apenas física, mas pode ser verbal, psicológica, afetiva, moral ou por meio do assédio:

[...] essa violência [contra a mulher] ela também não está só dentro de casa, está em outros departamentos, em outros lugares, na rua, no ônibus, no metrô. A

\footnotetext{
${ }^{3}$ Por se tratar de um trabalho com recorte de gênero, optou-se pela escolha do feminino para representar a categoria profissional de agentes comunitários, levando-se em consideração que o número de mulheres foi predominante nas unidades pesquisadas.
} 
violência doméstica é mais com a mulher, porque ela é mais indefesa, ela sente vergonha de falar que aquilo aconteceu com ela. Que nem no metrô, ela sofre assim: não é só a violência física, é a violência moral, o assédio (ACS 12-GF3).

As agentes retratam que a violência contra a mulher não está presente apenas em âmbito doméstico, privado e particular, mas encontra-se também nos espaços públicos. Essa violência já é tão rotineira que faz parte do cotidiano das pessoas e apresenta-se "na rua, no ônibus, no metrô ou em outros lugares" (ACS 12- GF3). Observa-se no relato das agentes um discurso de gênero ligado às características atribuídas ao feminino: "ela é mais indefesa, ela sente vergonha de falar que aquilo aconteceu com ela" (ACS 12- GF3). Segundo BOURDIEU (2014) os efeitos da dominação assumem muitas vezes a forma de emoções corporais por meio da vergonha, humilhação, ansiedade e culpa, ou de paixões e sentimentos por meio do amor, da admiração e do respeito. Pode se manifestar ainda através de emoções mais dolorosas, como por exemplo, o enrubescer, o gaguejar, o desajeitamento, o tremor, a cólera ou a raiva onipotente. Essas representações quanto à fragilidade feminina, o sentimento de vergonha ou mesmo a culpa pela situação de violência estão presentes não apenas no imaginário das agentes, e sim, no imaginário da mulher, sendo o resultado de sucessivas gerações.

Dentre as violências praticadas contra a mulher, as agentes entendem que as violências invisíveis são piores, pois, não deixam marcas corporais e não havendo provas, a denúncia não pode ser realizada. Destacam ainda que a violência psicológica inerente às humilhações, maus tratos e constantes ameaças de morte levam muitas mulheres a desenvolverem depressão e outras doenças, bem como o uso de remédios controlados:

\begin{abstract}
Então assim, principalmente a violência verbal ela é muito mais escondida do que [pausa] a física, porque a física você saiu na rua e todo mundo vê, se você tá machucado, se você tá... agora a verbal não. A pessoa fica ali magoada e vai guardando, vai guardando e com o tempo vem o que? Depressão, doenças sérias. A gente vê muita mulher passando em psicólogo, tomando remédio controlado, é isso, a violência doméstica, às vezes ela não está ali apanhando fisicamente, mas mentalmente, as palavras... (ACS 11- GF3).
\end{abstract}

As agentes apontam para a invisibilidade da violência psicológica a qual denominaram como violência verbal. Enfatizam que os resultados da violência física em comparação a violência psicológica são evidentes a qualquer observador. A violência psicológica, no entanto, embora apresente seus efeitos a médio e longo prazo, não é menos prejudicial e 
nefasta à mulher: "A pessoa fica ali magoada e vai guardando, vai guardando e com o tempo vem o que? Depressão, doenças sérias" (ACS 11- GF3). Esse relato demonstra o quanto a violência psicológica é negligenciada pela sociedade, além de seus efeitos nocivos à vida da mulher, que mesmo com ajuda profissional, não raramente, recorre ao uso de medicamentos controlados.

Segundo TESSER et al. (2010), o Programa Saúde da Família (PSF) inicialmente se propôs a superar a tendência medicalizante do modelo biomédico, substituindo-a por uma nova concepção apoiada na Promoção à Saúde. Essa reforma cultural, entretanto, não se concretizou, pois, seria necessária a reorganização da formação dos profissionais em larga escala. Como resposta a essa lacuna, surge à proposta de Acolhimento, divulgada pela Política Nacional de Humanização.

A proposta de Acolhimento envolve uma postura ética e de cuidado, respeitosa e empática ao usuário, direcionada à melhoria da relação serviços de saúde e comunidade. Enquanto a medicalização acentua a realização de procedimentos profissionalizados, diagnósticos e terapêuticos, o Acolhimento está voltado para abordagens mais ampliadas, levando-se em consideração os modos de vida dos indivíduos, fatores sociais e subjetivos do processo saúde-doença. Desse modo, aponta-se o Acolhimento como estratégia para lidar com eventos inesperados e com a demanda espontânea (TESSER et al., 2010). Sendo assim, as agentes comunitárias, ao acolherem as mulheres com histórico ou vivências de violência, inerente muitas vezes aos conflitos familiares, poderão contribuir para o processo de desmedicalização, além de estimular abordagens mais ampliadas.

Dentre os casos de violência vivenciados por mulheres, os profissionais da rede de assistência concordam que os casos mais recorrentes são de violência psicológica, emocional e verbal. A violência física também é mencionada, porém, os casos são menos frequentes e a demanda não é espontânea. As próprias agentes relatam que os casos de violência física são esporádicos:

Aqui no bairro, acho que não tem muito esse estado de violência, pra ter que ligar, acionar o Conselho Tutelar, acionar a polícia, a delegacia da mulher. Acho que não chega a tanto, ainda, aqui (ACS 13-GF3).

É importante questionar se os casos de violência física evidenciados correspondem de fato à realidade do território. Outro ponto relevante a considerar seria a existência da violência física por trás dos casos de violência psicológica. Para essa investigação, no entanto, o vínculo 
entre profissional e usuário se faz necessário, assim como o comprometimento e interesse do profissional por esta demanda, que por vezes, é negligenciada e desconsiderada.

A violência sexual é apontada pelos profissionais da rede de assistência para casos ou suspeitas de abuso infantil. Ou ainda, referindo-se à violência por parceiro íntimo ou estupros coletivos. As próprias agentes fazem referência a casos de violência por parceiro íntimo e a desconsideração dos profissionais da equipe por essa demanda, por meio de risos e brincadeiras, bem como pela desconfiança na veracidade dos fatos:

\begin{abstract}
[...] Uma senhora que vinha aqui, com setenta e poucos anos, e reclamou do marido que estava tentando fazer sexo com ela e ela não queria, não queria. Aí eu virei para a gerente e falei: "não é possivel, não vai fazer nada?" Aí a reação da gerente me deixou apavorada, ela disse: "mas será que é mesmo? Será que ela não está inventando?" Pelo amor de Deus, quando a mulher fala, a princípio você acredita nela, sempre (ACS 3-GF1).

No meu caso, também teve. Teve uma que tem transtorno mental e, todas às vezes que eu vou, ela fala que foi abusada, que não estava conseguindo nem sentar, que o homem foi no quarto dela... só que ela tem transtorno. Então eu trazia também essa queixa. "Ah, mas será? Será que não é coisa da cabeça dela?" (ACS 1-GF1).

Teve uma outra profissional de saúde, eи não sei de onde, que falou que quando o marido dela estava em casa, ela não ficava em casa. E depois daquela reunião, teve colegas nossas aqui de dentro que falou: "ah, mas não é bem assim, você sabe né, porque o marido quando quer, não tem como, a gente tem que fazer, é casado". Eu falei: "o seu marido entra no cio por acaso minha filha? É um animal? Porque quando quer, tem que ter de qualquer maneira?" Elas dizem: "Ah isso é criação, é conforme ele foi criado". É exatamente isso, é conforme a mulher foi criada para servir o homem, sendo que o homem tem necessidades e a mulher parece que não tem nenhuma necessidade. Ela também pode querer transar com o marido e o marido não querer, mas isso não causa sofrimento em ninguém. "É casada" me marcou mais ainda. "É casada, logo tem que ter sexo com o marido na hora que ele quiser". Isso aqui, colega nossa de trabalho. Ai! Pelo amor de Deus gente, para com isso. Se não quer, não é não. Não pra marido, pra namorado, pro rai'que parta. Em uma brincadeira dessa na reunião, pode ser verdade, porque muitas falam que não querem o marido em casa, muitas falam: "Meu marido está de férias, eu vou pra rua". Quando viaja dá graças a Deus. Todo mundo ouviu o comentário. "Graças a Deus, meu marido tá fora, to descansada" [referindo-se ao comentário da profissional em reunião de matriciamento] (ACS 3- GF1).
\end{abstract}

Verifica-se no relato das agentes a desconsideração dos profissionais da equipe pelos casos de violência sexual por parceiro íntimo, como se o sexo não consensual não fosse uma violência contra a mulher, mas simplesmente uma necessidade do homem, reforçada e legitimada pelos votos matrimoniais. Desse modo, o descaso e a banalização da violência são também reforçados pela dúvida e pelas brincadeiras dos profissionais, que reafirmam a posição de fragilidade e submissão da mulher em contraste com a figura masculina, símbolo de força e virilidade. Nesta perspectiva, as agentes apontam para a compreensão equivocada 
dos profissionais da equipe quanto à obrigatoriedade do sexo no casamento bem como a supervalorização da sexualidade masculina em detrimento da sexualidade feminina.

De acordo com a Lei n. 10.406/02 art. 1.550, inciso III do Código Civil Brasileiro, o casamento pode ser anulável por vício da vontade, nos termos dos arts. 1.556 a 1.558. Logo, se houve erro essencial por parte de um dos nubentes quanto à pessoa do outro, entendendo-se por "erro essencial", dentre outros apontamentos, o que diz respeito à sua identidade, sua honra e boa fama, de modo a tornar insuportável a vida em comum do cônjuge enganado, o casamento poderá ser anulado. Desse modo, a recusa em manter relações sexuais pode ser utilizada como pretexto ou justificativa para anulação do casamento ou alegação de divórcio (BRASIL, 2002b).

Levando-se em consideração a visão androcêntrica predominante na ordem social, a qual institui as diferenças entre os gêneros, naturalizando-as, não é de se estranhar que o feminicídio fosse justificado como crime em legítima defesa da honra. Segundo BOURDIEU (2014) a questão da honra masculina está associada à virilidade e potência sexual do homem. Assim, o homem, "verdadeiramente homem", deve buscar aumentar a sua honra, buscando a glória e a distinção na esfera pública. A mulher, por sua vez, cuja honra é negativa, podendo ser perdida ou defendida, encontra sua virtude na virgindade e fidelidade. Inclusive, em algumas sociedades, como na Cabília ${ }^{4}$, as mulheres são vistas como objetos de troca, sendo seu valor associado às alianças que podem ser produzidas pelo matrimônio, isto é, capital social, bem como a conquista de aliados prestigiosos, isto é, capital simbólico. A reputação feminina, sobretudo, sua castidade, representa a reputação masculina e a honra dos pais e irmãos, ou seja, o capital simbólico de toda a linhagem.

Neste sentido, a traição ganha diferentes conotações para homens e mulheres, aumentando a honra masculina, porém, diminuindo a honra feminina. Para as agentes comunitárias, a traição é considerada um tipo de violência psicológica, que afeta tanto a homens quanto a mulheres:

A traição é um tipo de violência. Às vezes a pessoa fica lá pra baixo porque foi trocada, "trocou o seu modelinho antigo, por um carro novo". Afeta o homem também, ele fica pra baixo, entra em depressão porque foi trocado por uma coisa melhor. E os dois não se valorizam (ACS 13-GF3).

\footnotetext{
${ }^{4}$ Região montanhosa do norte da Argélia. Faz parte da cordilheira do Atlas e é banhada pelo mar Mediterrâneo.
} 
Em uma sociedade de consumo, as relações se tornaram coisificadas. As pessoas são tratadas como mercadorias e podem ser facilmente substituídas. BAUMAN (2004), em seu livro "Amor líquido", aborda exatamente essa questão, com relação à fragilidade dos laços humanos e a flexibilidade com que são substituídos. As agentes retratam essa realidade, assim como o conceito das relações como mercadoria: “Às vezes a pessoa fica lá pra baixo porque foi trocada, trocou o seu modelinho antigo, por um carro novo" (ACS 13- GF3).

As agentes reiteram que, muitas vezes, a mulher se submete a uma condição de violência, pois, existe uma relação de ganho compensatória:

[...] ele tem uma amante e ela sabe, e ela não sai porque ele dá tudo pra ela (ACS 12- GF3).

É. O marido ganha muito. Deixa ele pegar as outras, mas ele pagando todas as minhas contas, viagens, o meu carro novo e tendo tudo lá na geladeira... (ACS 13GF3).

Isso já é uma violência contra a mulher, porque... ela tá aceitando essa condição, não tem amor próprio (ACS 12-GF3).

Acha que é favorável [referindo-se a mulher]. Deixa ele com as amantes. Eu saio, pego o personal de amante também, e fica assim (ACS 13-GF3).

Pode-se observar no relato das agentes a mercantilização das relações, em que, tanto homens quanto mulheres, vivem em função da satisfação própria. $\mathrm{O}$ outro se torna produto, podendo ser substituído com facilidade. Chama à atenção a fala de um dos agentes comunitários do sexo masculino (ACS 13-GF3): “Acha que é favorável [referindo-se a mulher]. Deixa ele com as amantes. Eu saio, pego o personal de amante também, e fica assim”. Embora essa pesquisa não tenha condições amostrais de generalizar características específicas relativas ao gênero, tratando-se apenas de 2 agentes do sexo masculino, vale ressaltar que essa "vingança de madame" representa uma fantasia tipicamente masculina. SANTOS et al. (2005), em pesquisa com agentes comunitários do sexo masculino, integrantes das Unidades de Saúde localizadas na Região Norte do Município de São Paulo, discutem as inquietações quanto ao "ser homem" e as "vivências das masculinidades" como uma questão de gênero. Apontam que os agentes são enfáticos e unânimes em dizer que as rodas de conversas entre homens têm como base a mentira, como, por exemplo: "comeu várias mulheres, às vezes até virgens...". Essas fantasias sexuais remetem, por sua vez, a noção de poder e virilidade associada à dominação masculina. 
FRANÇA (2018) ${ }^{5}$, em recente matéria publicada pela revista Época, intitulada: "A infidelidade de hoje: nunca foi tão fácil trair. Nunca foi tão difícil esconder. E agora?”, relata que a traição, apesar de fortemente condenável em virtude de uma ética cristã, tem se tornado cada vez mais comum e facilitada por inúmeros aplicativos de celular. Aponta interessante pesquisa realizada pelo Instituto Gallup nos Estados Unidos, em que 91\% dos entrevistados disseram que a infidelidade é moralmente condenável e mais detestável do que a poligamia, o divórcio e o suicídio. No entanto, as estatísticas revelam que a infidelidade nos Estados Unidos é de $26 \%$ a $70 \%$ entre elas e $33 \%$ a $75 \%$ entre eles. Outra pesquisa trazida pela autora, realizada no Hospital das Clínicas de São Paulo, há dois anos, com 8.200 pessoas, apontou que $50,5 \%$ dos homens e 30,2\% das mulheres já foram infiéis no relacionamento. Nesta perspectiva, a traição, considerada por muitos como um comportamento violento, pode ser entendida, como afirma Esther Perel (apud FRANÇA, 2018), como uma grande chance para tornar o matrimônio mais feliz.

Desse modo, a traição consentida, mencionada pelas agentes, é apenas um recorte das novas tendências e possíveis configurações dos relacionamentos modernos. Essa fragilidade dos laços humanos, no entanto, somada a um cenário de instabilidade social, de constante transformação e insegurança, tem potencializado a invisibilidade da violência bem como seu reconhecimento:

As pessoas não sabem o que é violência contra a outra pessoa. Hoje em dia você vê os jogos, os filmes..., as pessoas não sabem mais o que é violência direito. Antigamente, a gente sofria bullying na escola, mas ficava calado, não podia brigar, era só brincadeira naquela época. Hoje em dia, você olhou feio pra criança, chamou de gordo, você já tá fazendo bullying. Eles estão invertendo muito esse tipo de violência (ACS 13-GF3).

As agentes apontam para uma dificuldade de compreensão e clareza quanto ao conceito da violência. Por um lado, observa-se o estímulo à agressividade nos mais variados contextos, como por exemplo, nos filmes e nos jogos, e por outro lado, a discussão acalorada e amplamente divulgada pelos meios de comunicação e movimentos feministas. Esse debate tem crescido e encorajado novas frentes de pesquisa, como por exemplo, o bullying nas escolas. Para as agentes, no entanto, aquilo que antes era apenas considerado como uma "brincadeira de mau gosto", de repente ganhou a conotação de violência: "Antigamente, a gente sofria bullying na escola, mas ficava calado, não podia brigar, era só brincadeira

\footnotetext{
${ }^{5}$ Matéria escrita por Valéria França foi capa da Revista Época em 30-04-2018.
} 
naquela época. Hoje em dia, você olhou feio pra criança, chamou de gordo, você já tá fazendo bullying. Eles estão invertendo muito esse tipo de violência” (ACS 13-GF3). Assim as agentes parecem questionar até que ponto aquilo que tem sido denominado atualmente como violência, seria de fato uma violência ou uma questão relevante para a discussão.

Existe a compreensão, no entanto, de que a violência não é apenas contra a mulher, mas pode ser da mulher para com o homem, da mulher para com a outra mulher e ainda contra a criança ou contra o idoso:

No caso de violência contra o idoso e contra a criança é mais fácil, pois, a própria comunidade protege essas pessoas e não concorda com o maltrato delas (ACS 1 e 3 GF1).

Observa-se no relato das agentes, a dificuldade do profissional em lidar com a demanda de violência contra a mulher em comparação a violência contra a criança e contra o idoso. De acordo com a psicóloga do NASF, os casos de violência contra a criança e contra o idoso surgem com maior frequência na rede de serviços em comparação à demanda de violência contra a mulher. Neste sentido, é importante considerar as variáveis que podem estar associadas à baixa demanda dos casos de violência contra a mulher. Para a gerente da USF Vila Marlene, existe a compreensão equivocada do profissional de saúde quanto à autonomia da mulher para sair da situação de violência, o que não ocorre nos demais casos.

Segundo a gerente da USF Vila Esperança, na violência contra o idoso, por exemplo, esta se manifesta através da rotina imposta, da quebra de autonomia até a negligência e o abandono. Nos casos de violência contra a criança, esta é percebida desde a rejeição materna pela gestação até a repetição do ciclo de violência por meio de xingamentos, humilhações e agressões. Para a psicóloga do NASF, a coerção ao cuidado é um tipo de violência na qual a mulher está sujeita a assumir o papel de cuidadora na família, independente de sua vontade e ajuda dos demais envolvidos. Tratando-se da violência entre mulheres, essa é recorrente e, não raramente, os próprios profissionais de saúde são ameaçados. De acordo com a gerente da USF Vila Ana é necessário inclusive acionar a guarda.

6.1.1 Concepções dos Agentes Comunitários de Saúde sobre Mulheres em Situação de Violência 
De acordo com as agentes comunitárias de saúde, a violência contra a mulher tende a se tornar um ciclo, caso não seja interrompida desde o início, pois a pessoa se acostuma àquela situação e a trata como normal e tolerável:

Existe uma aceitação. É visto como um fato normal à mulher apanhar do companheiro. A própria mulher tolera essa situação (ACS 26- GF5).

É importante considerar que esse ciclo se perpetua e se reproduz pela manutenção e reforço do comportamento do casal. Neste cenário, as mulheres justificam as agressões verbais e humilhações do parceiro, sentindo-se muitas vezes responsáveis pela situação de violência. As agressões verbais se acentuam desdobrando-se em agressões físicas. A mulher se sente indefesa e em choque. Pensa inclusive que não tem mais o controle da situação. Para ganhar novamente a confiança da mulher, o companheiro ou ex-parceiro se mostra carinhoso e gentil, mas aos poucos, o casal desenvolve novas tensões, repetindo o ciclo (MINISTÉRIO PÚBLICO DO ESTADO DE SÃO PAULO, 2011).

Dentre as razões apontadas pelas agentes comunitárias para a mulher não fazer a denúncia e tolerar a situação de violência, destaca-se o medo do companheiro e das possíveis consequências. Mesmo para os vizinhos e familiares, a situação é delicada e o medo de represália evidente:

Toda a vizinhança sabia, mas ninguém denunciou ou chamou a polícia, pois, ele era usuário de droga e andava com um pessoal da pesada (ACS 26- GF5).

Observa-se que o medo do desconhecido paralisa e funciona como uma reação em cadeia: "Toda a vizinhança sabia, mas ninguém denunciou ou chamou a polícia" (ACS 26GF5). Perpetua-se, como afirma SCOTT (2005, p. 90), a "lei do silêncio que, num ato de cumplicidade forçada, amordaça tanto vizinhos quanto integrantes das equipes de PSF”.

Existe também a representação das drogas com a marginalidade e o mundo do crime: "[...] ele era usuário de droga e andava com um pessoal da pesada" (ACS 26- GF5). Segundo SCOTT (2005), não raramente, a equipe se mobiliza para atender as necessidades de um criminoso conhecido, sem deixá-lo esperando. De acordo com a gerente da USF Vila Ana, existe no território uma "rede de proteção social" formada pelos traficantes que administram e 
cuidam da ordem do local. Todos os problemas referentes à comunidade bem como a segurança dos profissionais de saúde são assegurados por eles. A médica da USF Vila Marlene aponta que, com frequência, acabam fazendo concessões para mulheres de traficantes de outros territórios que querem ser atendidas na unidade. Menciona que existe um acordo entre o "pessoal da FUMAS" [traficantes que vendem drogas nas moradias concedidas pelo governo] e os serviços de saúde, ou seja, eles respeitam e promovem a ordem no local desde que sejam respeitados, ou melhor, sem interferência ou prejuízo ao tráfico de drogas.

A médica da USF Vila Marlene relata que alguns casos são difíceis de lidar, pois, existe o medo e o receio do profissional. Menciona caso de adolescente em cárcere privado que o parceiro era subgerente do tráfico. Exemplifica dizendo que da mesma forma que os serviços de saúde não podem realizar uma palestra antidrogas na escola, "mexer" com a mulher do traficante pode ser considerado como uma infração das leis de convivência da comunidade. Enfatiza que alguns casos são possíveis realizar uma orientação em consulta, mas não de forma aberta. Esse relato demonstra a dificuldade dos profissionais quanto à abordagem das violências, além do limite estabelecido pelo tráfico e pelas leis de convivência da comunidade às práticas dos serviços e ações dos profissionais de saúde, que segundo SCOTT (2005), se encontram em um dilema entre a obrigação da denúncia e a manutenção de seu espaço de atuação na comunidade.

O medo e o receio da denúncia não são apenas dos profissionais de saúde, mas das próprias mulheres em situação de violência. As agentes apontam para a influência da mídia a reforçar o silenciamento dessas mulheres:

Muitas vezes a mulher visualiza na televisão alguém que passa o mesmo que ela e acaba morrendo. E pensa: "pode acontecer comigo". Então ela não toma uma atitude em fazer a denúncia (ACS 24-GF5).

O medo da impunidade, amplamente divulgada pela mídia, é comum e recorrente entre as mulheres. A falta de efetividade da Lei Maria da Penha bem como os casos de mulheres assassinadas com a Medida Protetiva são frequentes, o que agrava a invisibilidade da violência.

Essa invisibilidade é ainda reforçada pelas representações de âmbito privado e particular contidas no ditado popular: "em briga de marido e mulher, ninguém mete a colher". Neste sentido, as agentes comunitárias concordam que a esfera privada e particular do casal deve ser respeitada: 
Dentro da casa dele quem manda é ele, a hora que fecha as portinhas, você vai pra sua casa cinco horas, vai vir direto o dono do lar, o alfa, o macho e faz o que quer, a mulher faz o que quer, não cabe a mim me meter na vida domiciliar. Se ela apanha, se ela faz o que faz e não me conta, eu não posso intervir. A menos que a pessoa solicite ajuda, a intervenção ou orientação se torna difícil (ACS 17- GF4).

A compreensão das agentes quanto ao aspecto privado e particular das relações inviabiliza a reflexão nas questões de gênero, bem como a elaboração das ações pelos serviços de saúde. A assimilação dessas representações reflete na postura do profissional, o qual entende que não deve ultrapassar, sem permissão ou consentimento da mulher, o limite entre a esfera pública e privada. Dessa forma, esse ditado pode ser entendido como mecanismo de autoproteção, pois, ao segui-lo, o sujeito evitaria ser a próxima vítima do agressor (SCOTT, 2005).

Para o médico da USF Santa Gertrudes, quando há prejuízo a saúde da mulher, como é o caso da violência, o profissional deve intervir, porém, tratando-se de "problemas bobos", como discussões entre o casal, a intervenção não deve ser realizada. Questiona-se, entretanto, o que seriam "problemas bobos" e a qual violência o profissional se refere. Não seria essa classificação uma forma de ocultar ou banalizar a violência? Quanto à violência verbal, não seria também responsável pelos prejuízos à saúde da mulher? E por último, como ficariam as ações e a intervenção da equipe de saúde, se a violência verbal é desconsiderada?

Além das representações a respeito do aspecto privado e particular das relações, as agentes comunitárias consideram a autonomia e o poder de decisão da mulher para romper com o ciclo de violência, o que desfavorece na maioria das vezes as ações dos profissionais de saúde:

No caso da minha irmã que foi agredida pelo marido, eu sempre digo que posso ajudar, mas ela precisa decidir. Mas parece que a pessoa se acomodou, não quer correr atrás. Não adianta eu entrar no meio da briga, ela precisa decidir o que ela quer para vida dela (ACS 23- GF5).

Se ela não quer ser agredida, não quer violência doméstica, saia daquilo e se ela está aceitando dia após dia, ano após anos, é porque ela aceita aquilo. E uma, elas ficam viúva desses caras, sabem o que elas fazem? Casa com outro igual (ACS 6GF2).

Existe um discurso de responsabilização da mulher pela situação de violência, em que o sofrimento psíquico é desconsiderado, bem como as expectativas e representações dessa 
mulher quanto à família e o casamento. Essas representações, entretanto, fazem parte de uma realidade compartilhada socialmente e "quanto menos nós pensamos nelas, quanto menos conscientes somos delas, maior se torna sua influência” (MOSCOVICI, 2007, p. 42).

À mulher é conferido o poder de decisão, logo, confinada a solidão de sua escolha, precisa ainda arcar com os preconceitos e estigmas sociais. Cabe a esta decidir pela ruptura do casamento e enfrentar as angústias inerentes à separação, o regresso ao estágio de solteira, a educação dos filhos com a ausência do pai e os desafios do mercado de trabalho para os casos em que existe a dependência financeira do companheiro, enfim, a reconstrução de sua existência. Ou por outro lado, esta pode permanecer em situação de violência acarretando traumas emocionais e consequências à saúde, e ainda ser julgada pelos familiares, vizinhos e pessoas próximas como "acomodada", dentre outros adjetivos.

É possível considerar que as falas das agentes de valorização a autonomia e respeito à privacidade da mulher estejam apenas acobertando o medo latente em fazer uma intervenção ou orientação mais diretiva às mulheres em situação de violência:

Epa! Eu moro aqui, eu não vou me expor. Não vou expor minha família, meus filhos. Não faço [denúncia]. Eu tô cuidando da saúde, tô fazendo meu papel (ACS 1GF1).

Esse relato evidencia o medo da violência entre as agentes e as condições adversas às quais estão submetidas por fazerem parte da comunidade. Por se tratar de um território de tráfico, em que muitos moradores são dependentes químicos, as agentes encontram-se vulneráveis a possíveis agressões. Verifica-se também neste relato, a compreensão reducionista quanto ao cuidado em saúde e o papel do profissional, desconsiderando a demanda de violência como questão pertinente aos serviços de saúde.

O discurso de autonomia e responsabilização da mulher não representa, por sua vez, as agentes em sua totalidade:

Ela [a mulher] não tem autonomia, porque ela não tem escolha. Mesmo que ela saiba [tenha consciência da violência], ela não consegue sair, porque ela está extremamente fragilizada (ACS 3-GF1).

Existe a compreensão de uma parte das agentes comunitárias de que a mulher encontra-se fragilizada e sem condições de lidar com a demanda de violência. Logo, conferir 
a mulher "o poder de decisão" e não ajudá-la a solucionar o problema ou não intervir quando necessário já seria uma forma de violentá-la.

Dentre as concepções das agentes comunitárias às mulheres em situação de violência, observa-se que a dependência financeira, a dependência emocional ou mesmo o conforto proporcionado pelo companheiro contribuem para a permanência da mulher no relacionamento abusivo:

90\% delas já se acostumaram àquela realidade. Ah ele vai beber, vai fazer isso, mas amanhã tá tudo bem, a gente vai passear, a gente vai comer um cachorro quente ali na esquina, sabe, ele vai comprar um par de sapato pra mim e pronto. E no final, eles brigam, brigam e depois estão tudo aí se abraçando e se beijando (ACS 6GF2).

Eu acho que falta homem e quem tem o seu prefere apanhar e não abrir mão. Quem tem o seu não quer perder. Ruim com ele, pior sem ele (ACS 17-GF4).

Neste discurso, as agentes apontam a banalização da violência pela própria mulher, sendo essa entendida como "acomodada à realidade", apresentando falas, inclusive, de compensação ao comportamento violento do companheiro. É possível ainda perceber o descrédito das agentes quanto à situação de violência vivenciada pela mulher: "E no final, eles brigam, brigam e depois estão tudo aí se abraçando e se beijando" (ACS 6- GF2). Cabe questionar, no entanto, se esse quadro não mereceria uma atenção especial dos profissionais de saúde. Talvez, essa mulher precise se sentir apoiada, valorizada e encorajada a sair da situação de violência. Outro ponto destacado pelas agentes refere-se à dependência emocional dessas mulheres: "Eu acho que falta homem e quem tem o seu prefere apanhar e não abrir mão. Quem tem o seu não quer perder. Ruim com ele, pior sem ele" (ACS 17- GF4). Segundo BOURDIEU (2014), a mulher participa dos jogos de poder por procuração. Como sujeito a ser percebido pelo olhar do outro, essa necessita de um representante. É interessante considerar que muitas dessas mulheres, entretanto, são provedoras do lar e não dependem financeiramente do companheiro, porém, as representações sociais quanto ao casamento, à necessidade da mulher estar acompanhada e ser protegida por essa figura masculina permanecem e se reproduzem de geração em geração:

Ontem eu cheguei na casa de uma menina e eu fiquei impressionada. Ela trabalha o dia inteiro, já o marido volta e meia está em casa sem fazer nada. E ela estava correndo para arrumar a casinha dela pequenininha porque "não, ele vai chegar e vai perguntar: o que você fez?" E era o dia de folga dela. Ela trabalha doze horas no Giraffas. Ai eu olhei assim: "O teu marido vai chegar?" É o terceiro marido dela, todos nesse estilo. $O$ seu marido vai chegar cinco horas da tarde, você ai com bebê pequeno, preocupada se ele vai perguntar por que você não lavou a roupa 
toda e não arrumou a casa? Você tá de brincadeira. Ai a mãe dela estava perto e disse: "você não sabe como ele é. Ele chega em casa e fala um monte pra ela, como se ela não fizesse nada”. Eu falei: "por que você não pede ele para ajudar? $e$ sábado e domingo ele faz o que?". "Ele sai com os amigos. Eu vou apanhar qualquer dia do marido dela". Eu disse: "então você pega o sábado também e sai com os seus amigos". Ela disse: "você tá louca, ele me mata se eu sair com os meus amigos. Ele confisca celular, isso é uma agressão sem fim”. E é uma violência. E não sei o porquê, porque ela que trabalha pra manter aquela casa ali, entendeu. E ela gosta do camarada, dez anos mais novo que ela. Aí quis ter um filho com ele. Daí já é o terceiro filho, um de cada marido, tudo assim. Um está no Nordeste, o outro fica lá o dia inteiro, foi preso, soltou, e agora tem outro cara que a princípio não está metido em nada. E ela com medo, é uma mulher de trinta anos. Ela correndo pra arrumar a casa, "ah não que ele vai chegar". "Que é isso? Para com isso! Pede ele pra te ajudar". "Ah não, ele pergunta o que eu fiquei fazendo o dia inteiro em casa” (ACS 3-GF1).

Muito embora, os resquícios da submissão feminina, decorrentes de um processo de socialização que privilegia o homem, estejam presentes, é importante destacar o papel fundamental do trabalho para a independência, autonomia, pertencimento e significado da mulher. Vale ressaltar ainda, que a representatividade feminina em profissões intelectuais ou na própria administração é crescente e notória. No entanto, apesar de sua ascensão ao mercado de trabalho, a mulher não usufrui ou partilha dos mesmos direitos e privilégios do homem, encontrando-se praticamente excluída dos cargos de autoridade e responsabilidade, como por exemplo, nas finanças e na política (BOURDIEU, 2014). Desse modo, a dupla ou a tripla jornada de trabalho a qual está sujeita funcionariam quase como uma espécie de punição social por sua ousadia em romper a relação de dependência financeira com esse companheiro.

Neste sentido, é importante destacar que a independência financeira, através do acesso ao trabalho, é fundamental para a tomada de decisão da mulher e ruptura do relacionamento abusivo. Outros fatores, porém, como a dependência emocional do companheiro ou mesmo o histórico de violência pregresso devem ser considerados para a análise e compreensão quanto à permanência da mulher em situação de violência:

Pra mulher aceitar ser violentada, ficar naquela vidinha, tem uma explicação. Às vezes a mulher apanha um, dois dias, a gente acha que é simples, você pensa: "por que essa infeliz tá nessa vida?" Mas ela já vem de um histórico anterior de sofrimento (ACS 24- GF5).

Não raramente, a mulher violentada pelo parceiro já vivenciou ou presenciou situações de violência na casa de seus pais. Assim, a existência de um histórico de sofrimentos, abusos e traumas contribui negativamente para a percepção de outra realidade diferente da qual está 
familiarizada bem como para a ruptura do ciclo de violência. Neste sentido, aponta-se para a necessidade de conscientização da mulher, apoio e suporte através de uma rede de serviços articulada. Afinal, essa é uma temática complexa, que precisa ser considerada em toda a sua dimensão e uma análise simplista do problema pode ser muitas vezes responsável pela ausência de empatia, pela formação de preconceitos e julgamentos às mulheres. Desse modo, a permanência da mulher em situação de violência não deve ser associada somente à ausência de trabalho, mas ao contexto social, à dinâmica do casal ou mesmo as representações adquiridas ao longo da vida.

Vale ressaltar, que muitas vezes os profissionais da rede de serviços, também necessitam ser conscientizados, seja através da formação ou da capacitação continuada. No relato a seguir, por exemplo, observa-se a reprodução do discurso machista hegemônico incorporado e manifestado nas representações tanto de agentes do sexo masculino como do sexo feminino, em que o preconceito e o juízo de valor com relação às condutas femininas são determinantes e os próprios agentes não se apercebem disso:

Muitas vezes as mulheres usam roupas apertadas demais, chegam a ser tão
apertadas que ficam transparentes, marcam o corpo, marcam a roupa de baixo e
elas não querem que os homens não façam nada com elas? Bem aí o homem não
precisa fazer, mas ela não quer receber uma cantada? Muitas vezes as mulheres
não veem como se vestem (ACS 13-GF3).
Dá a impressão de que este é um pensamento machista dele, mas não é (ACS 12 -
GF3).

Segundo BOURDIEU (2014), a vestimenta da mulher está associada a "arte de viver feminina", da boa conduta, inseparavelmente corporal e moral, que por sua vez, se impõe sob uma disciplina incessante a todas as partes do corpo, exercida pela coação quanto aos trajes e penteados. Esse processo de socialização da mulher procura limitar os movimentos e deslocamentos de seu corpo. Ao contrário dos homens, que tomam maior espaço com seu corpo, sobretudo nos lugares públicos, as mulheres são chamadas ao confinamento, a dissimulação de seu corpo e a ordem.

É interessante pensar no discurso das agentes e na ênfase dada tanto por homens quanto por mulheres ao vestuário feminino, como se esse fosse o grande responsável pela situação de violência a qual a mulher está submetida. Novamente a mulher é responsabilizada pela violência sofrida, enquanto o homem é desculpado de sua atitude pela justificativa de uma sexualidade descontrolável. Assim, questiona-se: Que construção de masculino é esta? E como é possível ajudar uma mulher considerada culpada pela situação de violência? 
6.1.1.1 Fatores que Contribuem para Desencadear ou Reforçar Situações de Violência contra a Mulher

As agentes comunitárias concordam que a violência está enraizada na sociedade e as representações sociais atribuídas a homens e mulheres contribuem para reforçar o comportamento violento e a cultura machista:

\footnotetext{
Muitas vezes você nasceu, você é um menininho, e você cresceu vendo o seu pai fazer isso, seu avô fazendo isso com a esposa dele, o pai com a mãe. É uma questão cultural (ACS 13-GF3).

Eu tenho dó dos pequenos, estão crescendo em um ambiente assim, tá vendo isso né. Realmente, quando a gente é pequeno, a gente fala: "ah, quando eu crescer eu vou ser igual o meu pai ou igual a minha mãe". Ai, a criança olha e diz: "ah, quando eu crescer vou ser igual meu pai, vou ter uma mulher e arrebentar ela na porrada também". É bem assim (ACS 7-GF2).
}

Observa-se, no discurso das agentes, a retomada do ciclo de violência como consequência do aprendizado da criança pela vivência em casa. A internalização de padrões de pensamento e comportamento pode ser percebida pelas falas e atitudes das crianças. Assim, as representações de gênero se constituem desde cedo e são uma herança cultural. Neste sentido, a psicóloga da "Casa Sol” faz menção à fala de uma menina, descontente com a permanência em casa de acolhimento, à sua mãe: "Mãe, você deveria ter ficado quieta". Em sua mente juvenil, a mãe poderia ter evitado a situação de violência e sua repercussão, caso houvesse ficado calada. A fala dessa menina é sintomática e demonstra claramente a incorporação da ordem masculina desde a tenra infância, inscrita por sua vez, nos corpos, na divisão sexual do trabalho e nos rituais públicos e privados (BOURDIEU, 2014).

Desse modo, as crianças aprendem a diferenciar e a enxergar os gêneros de acordo com os atributos conferidos socialmente a cada um deles. Ao homem, por exemplo, espera-se que seja provedor e protetor, apresentando características como força, agressividade e dominação. Quanto à mulher, espera-se que assuma os encargos domésticos e as funções de cuidado, além de apresentar os atributos da "feminilidade" como sorrir, ser simpática, atenciosa, submissa, discreta, contida ou apagada (BOUDIEU, 2014).

De acordo com a médica e a gerente da USF Vila Marlene, a imposição dos papéis entre homens e mulheres é violenta. O homem é educado a enxergar a mulher como frágil, submissa e responsável pelos afazeres domésticos, enquanto a mulher é ensinada a idealizar o 
casamento e a desenvolver uma dependência emocional do homem. Segundo a gerente da USF Vila Marlene, a mulher é vista como sexo frágil, dependente, e que necessita de proteção, e não como profissional competente e independente. Neste sentido, as próprias agentes comunitárias reforçam a representação da mulher como sexo frágil:

[...] Um homem, se ele dá um tapa em você, ele te arrebenta, um tapa te arrebenta. Eles usam da força bruta, porque sabem que a mulher não vai ter como reagir. [...] porque a mulher é o sexo frágil. Por mais que nós queiramos nos igualar a eles, em pagar a conta, em ver tudo que eles fazem lá fora e fazer a mesma coisa, eu bato na mesma tecla: "eu sou mulher, eu sou feminina, eu sou frágil”. Nunca quero me igualar a um homem. Pago minhas contas sim, porque eu tenho capacidade, não porque sou igual, ou melhor, eu sou única (ACS 17-GF4).

É interessante pensar na ênfase dada à força física do homem em contraste com a "fragilidade feminina", assim como a concepção da figura masculina ligada à esfera pública e a figura feminina à esfera privada. Nota-se, no relato das agentes, a discrepância entre os gêneros, bem como a reprodução do discurso machista: "Por mais que nós queiramos nos igualar a eles, em pagar a conta, em ver tudo que eles fazem lá fora e fazer a mesma coisa, eu bato na mesma tecla: eu sou mulher, eu sou feminina, eu sou frágil” (ACS 17- GF4). Neste discurso, feminilidade é sinônimo de fragilidade. Assim, observa-se a tentativa de atenuar o conteúdo machista manifesto, por meio de falas compensatórias de valorização a mulher: "Nunca quero me igualar a um homem. Pago minhas contas sim, porque eu tenho capacidade, não porque sou igual, ou melhor, eu sou única" (ACS 17- GF 4).

Segundo BOURDIEU (2014), a submissão feminina pode ser voluntária, pois, o efeito da dominação simbólica vai além, muitas vezes, da consciência, da cognição e da vontade. Afirma que, durante o processo de socialização, a mulher encontra-se sujeita à "violência simbólica" pelo reconhecimento e a incorporação de critérios e padrões do discurso dominante. Assim, os esquemas de pensamento feminino tornam-se produtos dessa ordem simbólica, mediante a naturalização das relações de poder.

Esse processo de socialização, descrito por Bourdieu, clareia a compreensão quanto às razões para a permanência da mulher em situação de violência. Ou seja, a dificuldade em romper o relacionamento abusivo pode estar relacionada, dentre outros fatores, às representações que foram internalizadas e constituem a sua forma de ser e entender o mundo. Desse modo, essas representações podem estar dificultando a percepção e a compreensão da realidade abusiva, bem como a possibilidade de ruptura com o ciclo de violência. 
No relato a seguir questiona-se o processo de socialização ao quais homens e mulheres estão submetidos, sendo o homem privilegiado e a mulher responsabilizada pela violência sofrida:

Não tem ensinamento do homem, tem ensinamento da mulher a se proteger. Para o homem não bater, não tem. Tem para você fazer o que? Não sai de casa a noite, não use saia curta, não fale, não provoque, deixe o marido não sei o que lá (ACS 3GF1).

Embora a categoria de gênero seja amplamente debatida e discutida quanto a sua inserção nas escolas, em especial pelo questionamento do sexo biológico como natural e determinante das identidades de homens e mulheres, outras apropriações do conceito devem ser levadas em consideração e se fazem extremamente necessárias e urgentes, como por exemplo, a luta pela igualdade de direitos e oportunidades, o acesso e a distribuição de poder entre os gêneros, além da reflexão cuidadosa quanto às representações atribuídas a homens e mulheres, construídas socialmente, porém rotuladas como naturais:

É uma coisa que foi muito arraigada dentro da cultura, da sociedade em todos os países, que a mulher muitas vezes não tem tanto poder. Não tem poder, tem que ficar em casa, cuidar dos filhos, e ser submissa ao marido, ao homem. Mas são coisas que a gente não vê (ACS 13-GF3).

Verifica-se no relato das agentes como as representações atribuídas ao feminino e ao masculino estão naturalizadas. E o mais preocupante: de tão naturais e corriqueiras tornam-se imperceptíveis, ou melhor, invisíveis. Embora hoje os casamentos não sejam mais duradouros e a mulher tenha conquistado maior autonomia e independência através de sua ascensão ao mercado de trabalho, os resquícios dessa submissão podem ser evidenciados de geração a geração.

Segundo a gerente da USF Vila Esperança, existe ainda a concepção da relação matrimonial perpétua, em que a mulher é tratada como objeto de uso e posse masculina, pautando-se na obrigatoriedade do sexo, independente de sua vontade e das condições do parceiro.

Tanto a submissão feminina quanto o sentimento de posse masculino perpassam às relações de poder estabelecidas entre homens e mulheres. De acordo com o médico da USF Santa Gertrudes, entre as próprias mulheres existe uma disputa muito grande, e a ausência de 
apoio mútuo é evidenciada pelas fofocas e difamações à imagem daquela que se encontra em situação de violência. Essa percepção da mulher, embora não seja infundada, não pode ser utilizada como parâmetro ou regra para determinar as relações entre mulheres. Afinal, mulheres criam, sim, redes de apoio e são solidárias. Prova disso é o grupo de psicologia do NASF, apontado pelos profissionais de saúde como importante estratégia dos serviços a favorecer essas redes de apoio entre as mulheres. Neste sentido, a psicóloga do NASF afirma que as próprias mulheres durante os grupos de escuta se mobilizam e ajudam umas as outras, por meio dos discursos e experiências compartilhadas.

Essas relações de poder, socialmente aceitas, levam muitos homens, por sua vez, a não reconhecerem a violência praticada contra a mulher:

Ele não acha que é uma agressão, ele quer transar com a mulher, transa qualquer hora e ele acha que aquilo é um padrão pra ele seguir (ACS 3-GF1).

Da mesma forma que os homens não reconhecem a violência praticada, outras vezes, a própria mulher não se apercebe da realidade abusiva ou não enxerga a violência como uma violação de direitos. Essa invisibilidade favorece a perpetuação do ciclo de violência:

A mulher não tem força para combater e isso é um ciclo aqui. E é um ciclo constante aqui, você vê se repetir sempre. Você não consegue parar, você vê que vai acontecer, as meninas começam a engravidar e engravidam porque querem. Dependendo da pessoa que ela fica grávida, ela segura o cara e o cara quer ter o filho com ela. Depois que ela tem o filho com o cara, ele vira o dono dela. Ela perde toda a liberdade que ela tem. Ela não consegue mais sair. O medo é muito grande. O medo paralisa, você nem pensa (ACS 3-GF1).

Verifica-se no relato das agentes uma cultura de violência na comunidade, em que as adolescentes vivenciam realidades abusivas pela escolha de parceiros dominadores e possessivos. A violência, entretanto, está naturalizada de tal maneira, que as adolescentes desejam engravidar desses parceiros como garantia da continuidade do relacionamento. Como consequência, se tornam prisioneiras desse relacionamento. Paralisadas pelo medo, perdem sua autonomia e são subjugadas ao domínio masculino. Outro fator a contribuir para a gravidez precoce na adolescência está relacionado à expectativa do amor incondicional entre mãe e filho. Essa alternativa é vista, por vezes, como meio compensatório a suprir o vazio do relacionamento amoroso. 
Para os profissionais da rede de assistência, a violência é um ciclo que se repete de geração em geração. Observam que muitas dessas mulheres, por terem sido privadas de afeto e amor na infância, além das vivências de violência e abuso por parentes ou pessoas próximas, desenvolvem traumas e baixa autoestima. Não raramente, essas mulheres procuram parceiros violentos como o pai, e mesmo quando apresentam consciência da violência sofrida, não conseguem se desvencilhar e elaborar o trauma. Essas vivências de violência e abuso refletem, por sua vez, na relação com seus filhos, que são tratados, de igual modo, por meio de xingamentos e humilhações e aprendem desde cedo a praticar a violência.

Vale ressaltar que o não reconhecimento ou a banalização da violência pela própria mulher agravam sua invisibilidade. É importante salientar que essa banalização, assim como a repetição do ciclo de violência estão atreladas às construções de gênero que conferem ao feminino um lugar de confinamento, passividade e submissão, restrito a esfera privada. Outros fatores, como o descomprometimento social, contribuem neste sentido. De acordo com a gerente da USF Centenário, muitas vezes "as pessoas fazem vista grossa e preferem não interferir para não serem inconvenientes ou não se comprometerem”. Nos serviços de saúde, diferente de outras demandas assistenciais que são alvo de discussão durante as reuniões e conversas entre os profissionais, a violência passa despercebida, ou quando se torna pauta de discussão, esgota-se ali. Isso denota a invisibilidade do problema e reforça a ideia de que mesmo quando existe o reconhecimento dos casos de violência, os profissionais, movidos pela conveniência e comodidade, preferem não se posicionar ou fazer "vista grossa" (BATISTA, 2005).

Segundo a gerente da USF Vila Esperança, muitas mulheres são negligentes e omitem a violência por vergonha ou por não desejarem a exposição. Para a gerente da USF Santa Gertrudes, no entanto, a impunidade ou mesmo a demora na resolução dos casos, prejudicam a tomada de atitude da mulher, que por vezes não faz a denúncia ou acaba retirando a queixa. Neste sentido, é interessante pensar se existe de fato uma negligência por parte dessas mulheres, ou se a negligência seria do próprio Estado ao não tornar efetiva a Lei que assegura os direitos dessas mulheres.

Dentre outros fatores que contribuem para desencadear situações de violência doméstica contra a mulher, as agentes comunitárias apontam para o abuso de substâncias psicoativas, como o álcool e as drogas: 
Neste relato, as agentes apontam para a estreita relação entre o uso de bebidas alcoólicas e a prática da violência. A gerente da USF Vila Marlene ressalta inclusive que o abuso de substâncias psicoativas é muito comum no território, totalizando 100 pacientes usuários de drogas ou etilistas. Enfatiza que a violência emocional, referente aos xingamentos e acusações do companheiro, filhos e familiares está associada, em grande medida, ao uso dessas substâncias. Neste território destaca que a violência é praticada especialmente dos filhos para com os pais, devido ao alto índice de adolescentes usuários de droga.

Para as agentes comunitárias, os meios midiáticos exercem grande influência na reprodução do comportamento violento:

As novelas desde 1980 já mostravam cenas de violência contra a mulher, de homens agredindo mulheres e mulheres querendo tirar vantagens das outras. Você vê tanto essas situações nas novelas que acaba se tornando uma coisa normal (ACS 13$G F 3$ ).

Observa-se neste discurso, que a constante divulgação de atos de violência pelos meios midiáticos favorece a banalização da violência, tornando-a familiar e rotineira ao público, porém, sem a devida conscientização de suas causas, efeitos e consequências.

Para a assistente social do NASF, a divulgação detalhada pela mídia da crueldade dos casos de violência contra a mulher poderia ser substituída por uma mídia mais acolhedora e protetiva. Para o Coordenador do Consultório de Rua, o enfoque das ações não pode ser na violência, mas sim, "na garantia de direitos e, como já dizia Gandhi, na produção de uma cultura de paz".

Neste sentido, o médico da USF Santa Gertrudes aponta para os "mecanismos de controle da violência", os quais ele define como sendo o estímulo a tudo aquilo que não é violência. Assim, sugere o estímulo à maternidade nas mães, o desenvolvimento de ambientes adequados nas escolas e a retirada dos adolescentes das ruas, pela construção de políticas voltadas ao jovem.

É fato, não há como negar o aumento da violência e da intolerância no mundo. No entanto, pregar uma cultura de paz e "estimular tudo aquilo que não é violência", talvez funcione apenas como medidas paliativas, afinal não há como "tampar o sol com a peneira", pensar em políticas e ações desconsiderando o contexto social, as desigualdades e preconceitos arraigados na sociedade. 
De acordo com SCOTT (2005), a política territorializada dos programas de PACS e PSF contribuiu para consolidar uma política específica de gênero na saúde, favorecendo o acesso das mulheres às unidades especiais (PAISM). Neste sentido, observa-se que as ações dos serviços estão direcionadas para mulheres e crianças. Chama a atenção, no entanto, essa configuração dos serviços e a falta de atenção à saúde do homem, reforçando alguns estereótipos como "homem que é homem, não adoece".

Em estudo realizado nas Unidades de Saúde localizadas na região Norte de São Paulo com agentes comunitários a respeito de suas inquietações com as masculinidades, esses profissionais apontaram que embora sejam homens, foram treinados e capacitados para cuidar das mulheres e das crianças. Dessa forma, continuam sem saber como cuidar da saúde do homem, inclusive remetem à ausência de cuidados consigo mesmos (SANTOS et al., 2005). Isso denota a emergência em repensar o gênero no PSF, de modo a contribuir para transformações que promovam uma sociedade mais democrática e igualitária (SCOTT, 2005).

Nesta perspectiva, o município de Jundiaí apresenta, segundo a assessora de políticas para as mulheres, importante projeto desenvolvido pela UGADS (Unidade de Gestão de Assistência e Desenvolvimento Social) para o combate à violência com presos do Centro de Detenção Provisória "Marcos Antônio Alves Bezerra" de Jundiaí, que respondem por crime de violência doméstica.

6.1.1.2 O Olhar dos Agentes Comunitários sobre as Justificativas da Mulher para a Permanência em Situação de Violência

Para as agentes, a permanência da mulher em situação de violência está associada a causas multifatoriais:

Cada uma [mulher] tem um pensamento e a gente não sabe o que ela tá sentindo na pele. "Uma pode ser por causa de filho, outra por causa de amor, outra porque o filho é pequeno e acha que a criança não vai ficar bem com a separação" (ACS 7GF2).

Observa-se a percepção das agentes quanto à singularidade da mulher, bem como a compreensão de suas razões particulares para a permanência em situação de violência. 
Demonstram ainda empatia pela mesma ao considerarem sua particularidade e não pronunciarem julgamentos: "Cada uma [mulher] tem um pensamento e a gente não sabe o que ela tá sentindo na pele" (ACS 7- GF2). No entanto, o discurso de responsabilização da mulher permanece na retórica de algumas das agentes:

Gosta de apanhar, porque tem gente que gosta. Existe gosto pra tudo (ACS 6-GF2).

Chama a atenção o conteúdo machista desse relato e a banalização do sofrimento psíquico da mulher. BOURDIEU (2014) aponta que um dos traços da dominação é atribuir à mulher a responsabilização por sua própria opressão, como se essa escolhesse ser submissa ou gostasse dos tratamentos a ela infligidos. Observa que por vezes a mulher é culpabilizada por sua tendência a submissão. Explica, no entanto, que essa subordinação advém da construção do poder simbólico, "inscrito duradouramente no corpo dos dominados sob forma de esquemas de percepção e de disposições que o tornam sensível a certas manifestações simbólicas de poder" (BOURDIEU, 2014, p. 53).

É importante considerar, entretanto, como ficam as ações dos profissionais de saúde, se existe a percepção de que a mulher é culpada pela violência sofrida. Deste modo, outros elementos são trazidos para a análise:

Quem é que gosta de apanhar? De não ser respeitada? Alguma coisa, como pode gostar, então ela deve ter sim, uma baixa autoestima né, porque se gostar, como se gosta de apanhar? (ACS 26-GF5).

O questionamento da agente "quem é que gosta de apanhar?" (ACS 26- GF5) é extremamente relevante para a discussão. Será que de fato alguma mulher se agrada de ser violentada? Segundo a psicóloga do NASF, a mulher pode ter participado do jogo da sedução, mas não ter pedido para ser violentada. A concepção da mulher que gosta de apanhar remonta a uma fantasia sexual do homem, um fetiche com base nas representações da mulher como objeto e posse masculina. Outro subsídio trazido para a análise refere-se à autoestima da mulher, em que a presença da mesma é sinônimo de respeito próprio, enquanto sua ausência pode ser considerada, dentre outras variáveis, uma justificativa para a permanência da mulher no relacionamento abusivo.

O medo de represália como consequência do desdobramento da denuncia é destacado pelas agentes como sendo um fator recorrente entre as mulheres, assim como o medo de 
reiniciar a vida sem o companheiro, acrescido dos desafios inerentes a essa decisão, levam muitas mulheres a aceitarem as agressões:

Ela não trabalha, depende dele para o sustento, não tem para onde ir, muitos filhos... bem ou mal, ruim com ele, pior sem ele (ACS 12-GF3).

O tempo passou, não trabalhou, tá com a carteira limpa, mais de quarenta anos sem trabalhar, fica difícil de arrumar serviço (ACS 24-GF5).

A dependência financeira, assim como a falta de capacitação, formação ou mesmo a ausência de vínculo empregatício durante tantos anos geram insegurança e desmotivação na mulher, que muitas vezes não consegue se reinventar diante dessa situação. Observa-se que esta dependência vem ainda acompanhada de falas de compensação para a permanência da mulher em situação de violência: "bem ou mal, ruim com ele, pior sem ele" (ACS 12- GF3). É como se essa justificativa já fosse esperada e até mesmo aceitável entre as mulheres.

Para o médico da USF Vila Esperança, as mulheres calculam o risco e o benefício em permanecer em situação de violência. Ou seja, é melhor ser violentada e garantir a segurança da família, pela provisão das necessidades básicas pelo companheiro, ao invés de reconstruir a própria existência. Muito embora hoje a mulher tenha o respaldo da Lei Maria da Penha, em vigor desde 07 Agosto de 2006, a qual assegura no art. 22 inciso V, a prestação de alimentos provisionais e provisórios e no art. 23 inciso I, o encaminhamento da mulher e de seus filhos e demais dependentes para casas-abrigo e programas de proteção e acolhimento (BRASIL, 2006).

Dentre outros fatores para a permanência da mulher em situação de violência, destacase a dependência emocional do companheiro:

Às vezes ela ama tanto a pessoa que não quer largar. Fica preocupada se a pessoa for presa (ACS 24-GF5).

NOBREGA e MIRANDA (2013) apontam para a dialética do amor e da violência, destacando o contraponto estabelecido entre marido ideal/companheiro exemplar e agressor. Nesta perspectiva, a trajetória da mulher para a ruptura do ciclo de violência envolve a desconstrução do companheiro ideal, a compreensão do cenário de violência e suas significações, bem como o empoderamento dessa mulher.

É interessante pensar no relato das agentes: "Às vezes ela ama tanto a pessoa que não quer largar. Fica preocupada se a pessoa for presa" (ACS 24- GF5). De acordo com DINIZ e 
PONDAAG (2006), a mulher é ensinada desde cedo a sacrificar e negligenciar suas necessidades para a manutenção da vida familiar. Logo, o cuidado com o marido, os filhos, a casa e o casamento torna-se sua prioridade e como consequência, não raramente, sua subjetividade e identidade são esquecidas. A característica de abnegação e esquecimento próprio reflete, todavia, na insistência da mulher em tolerar a violência e permanecer no casamento.

Seja pela rotina, comodismo ou conveniência, as falas de compensação da mulher, segundo as agentes comunitárias, para justificar ou atenuar o comportamento violento do companheiro, são inúmeras:

Não, mas ele cuida da casa, ele arruma, ele faz comida pra mim, ele pega os filhos na escola... Essa fala de compensação, ele faz isso, mas, como se ele também não fosse responsável por fazer. Isso faz parte do relacionamento. Não é nada de mais o que ele está fazendo (ACS 3-GF1).

Ah, ele é uma boa pessoa, ele fez isso porque bebeu e estava nervoso (ACS 24GF5).

Nesse relato, as agentes fazem uma crítica à conformidade da mulher pela situação de violência e à legitimação desse agressor, que recebe o consentimento feminino, por meio de falas de compensação, para a repetição de novas agressões. Além disso, apontam para a compreensão equivocada da mulher ao desconsiderar a responsabilidade do homem nos afazeres domésticos e aceitar a distribuição desigual das tarefas.

Para os profissionais da rede de assistência, além dos aspectos mencionados pelas agentes comunitárias de saúde para a permanência da mulher em situação de violência, podese considerar o sentimento de vergonha pelas marcas corporais, a dependência social/status, já que muitas delas são mulheres de traficantes, o medo de solidão/carência, a falta de apoio dos familiares, a banalização da violência ou ainda a intenção de não criar conflitos e exposição.

De acordo com a delegada de polícia, muitas vezes, a mulher encontra-se em condição de culpa e fragilidade, considera a importância dos votos matrimoniais firmados no casamento e tem a intenção de organizar a família. Segundo a profissional de Segurança Pública, tanto a mulher quanto o companheiro não entendem o que está acontecendo e não sabem como quebrar o ciclo de violência. A mulher não compreende qual o seu papel e o esposo, assim como os filhos, encontram-se perdidos e desorientados. 
6.1.1.3 Modos pelos quais as Mulheres Enfrentam a Situação de Violência no Relato dos Agentes Comunitários

Dentre os aspectos de enfrentamento da mulher identificados pelas agentes comunitárias para a ruptura do ciclo de violência, aponta-se a autoestima como fator determinante:

Eu acho que se ela tiver autoestima, ela tem tudo, com certeza; mas se também não quiser mudar [pausa], não vai sair dessa vida nunca (ACS 10-GF2).

Em seus discursos, as agentes responsabilizam a mulher pela permanência em situação de violência e pela baixa autoestima, desconsiderando o contexto de adversidade em que essas mulheres estão submetidas. Outro ponto importante a considerar é que, muitas vezes, o desejo pela mudança não é suficiente para concretizá-la. A falta de clareza quanto ao caminho a ser trilhado e a própria condição de fragilidade da mulher dificultam o processo de superação da violência. Logo, o encorajamento e fortalecimento dessa mulher se fazem necessários. Neste sentido, caberia a criação de um guia de serviços para mulheres em situação de violência, semelhante ao guia de serviços ${ }^{6}$ desenvolvido pelo Coletivo Feminista Sexualidade e Saúde da Faculdade de Medicina da USP, sendo este disponibilizado para a consulta das mulheres na rede de assistência. Além disso, a sinalização dos serviços oferecidos nas unidades de saúde e demais organizações do município, por meio de cartazes, por exemplo, poderá contribuir para direcionar as mulheres a buscarem apoio e suporte nos serviços da rede de assistência.

Neste sentido, as agentes comunitárias apontam a imersão da mulher no trabalho como fator decisivo para a autoestima e enfrentamento da situação de violência:

[...] eu falei para ela trabalhar, para a autoestima dela. E realmente, hoje é uma pessoa que tá até gorda, antes era uma pessoa acabada, depressiva, hoje está bem. Ela mudou e começou a mudar ele também. Acho que para você mudar o outro, você se mudando, você já muda o outro (ACS 6-GF2).

\footnotetext{
${ }^{6}$ Coletivo Feminista Sexualidade e Saúde. Mulheres em situação de violência: guia prático de serviços. São Paulo (SP): Universidade de São Paulo, Faculdade de Medicina; 2002.
} 
Observa-se neste discurso a estreita relação entre trabalho e autoestima. Nesta compreensão, o trabalho seria equivalente à saúde e bem-estar, uma mudança pessoal, refletida no estilo de vida da pessoa. Para as agentes, inclusive, a mudança da mulher influenciaria no processo de mudança do agressor. Mais uma vez, verifica-se a responsabilização da mulher por sua autoestima como também pelo processo de mudança pessoal. Acrescenta-se, porém, uma terceira variável, que seria a responsabilização da mulher pelo processo de mudança do companheiro. Sendo assim, é como se a ruptura do comportamento violento estivesse condicionada a mudança de postura da mulher. Logo, a mulher que não exerce atividade remunerada e permanece em situação de violência é vista como acomodada ou oportunista. Nesta perspectiva, as tarefas domésticas e o cuidado com os filhos, companheiro e familiares são desconsiderados como forma de trabalho.

Parte das agentes, no entanto, compreende a importância do fortalecimento da mulher para a ruptura do ciclo de violência. Neste sentido, apontam os serviços de saúde e o apoio dos familiares como fundamentais para a recuperação da mulher:

Para a mulher chegar a decisão de se separar é porque ela já sofreu demais, mas ela só tomou essa decisão porque ela tinha apoio dos pais, senão, ela continuaria apanhando (ACS 4- GF1).

O grupo de psicologia do NASF é destacado, por sua vez, como principal estratégia dos serviços de saúde para o atendimento de mulheres em situação de violência:

A mulher precisa ter autoestima, se sentir útil. Neste sentido a saúde pode contribuir com o grupo do NASF. Estes profissionais podem ajudar a mulher a se levantar e a andar com as próprias pernas (ACS 24- GF5).

De acordo com a assistente social do NASF, o trabalho em grupo ajuda a encorajar muitas mulheres, ao ouvirem a experiência de outras. Segundo a profissional, algumas mulheres apresentam um grau de maturidade e resiliência para trabalhar com a própria demanda de violência. Consideram as orientações em grupo e procuram investir em outras atividades, como por exemplo, atividade física, lazer e trabalho, estabelecendo outro tipo de relacionamento com o companheiro. Para a assistente social do NASF, no entanto, algumas mulheres se acomodam à situação pela dependência financeira ou pelo medo de enfrentar uma realidade diferente da qual estão acostumadas. Em outros casos, apesar da insatisfação com a situação de violência, essas mulheres se refugiam no trabalho. 
Para as agentes comunitárias, o grupo de psicologia do NASF destaca-se como importante estratégia para o auxílio de mulheres em situação de violência. No entanto, apontam para a descontinuidade das ações e a expectativa do tratamento individual pelo usuário como questões a serem pensadas. Neste sentido, a psicóloga do NASF pontua que o tratamento individual dificilmente ocorre, pois, o NASF, em geral, trabalha com o acolhimento e o grupo de escuta, o que favorece a mobilização dos participantes e ajuda mútua, por meio dos discursos e experiências compartilhadas. As agentes enfatizam, entretanto, a necessidade de um tratamento efetivo e contínuo:

A mulher precisa de um atendimento especializado, para ela se sentir mais fortalecida e encorajada. Ela precisa ter apoio psicológico, facilidade de acesso, recursos próximos para que ela possa realizar o tratamento (ACS 26-GF5).

É interessante considerar que para a efetividade desse tratamento, não é suficiente oferecer um serviço de qualidade, com profissionais capacitados, mas também pensar na facilidade de acesso a esses recursos, possibilitando a adesão da mulher ao tratamento bem como sua continuidade. Além disso, outras medidas, como a promoção de lazer, são mencionadas como variáveis a contribuir para o fortalecimento e a qualidade de vida da mulher:

Se você trata no início, vai no psicólogo, começa a sair, ter momentos de lazer, já melhora. Do contrário, vai ficar a vida toda dependendo de remédio (ACS 11GF3).

O tratamento psicológico dessa mulher e o investimento em atividades significativas e prazerosas podem contribuir para a felicidade no momento presente, a qual SELIGMAN (2009, p. 162) compreende por dois aspectos bastante distintos: prazeres e gratificações. Segundo o autor, "os prazeres são satisfações com claros componentes sensoriais e fortemente emocionais". Além de passageiros, envolvem pouco ou nenhum raciocínio. Quanto às gratificações, explica que se tratam das atividades que gostamos muito de praticar, não sendo necessariamente acompanhadas por qualquer sensação natural. São atividades que nos absorvem e perdemos a noção do tempo, como por exemplo, a leitura de um bom livro, uma boa conversa ou a prática de um esporte. As gratificações são mais duradouras que o prazer, e envolvem, por sua vez, o raciocínio e a interpretação. Estão apoiadas em nossas forças e 
virtudes, as quais o autor entende como sendo um traço, uma característica psicológica marcante, que pode ser observada em diversas situações.

Em algumas circunstâncias, as medidas adotadas por mulheres para o enfrentamento da violência são intrigantes e até mesmo questionáveis. Em alguns casos inclusive a mulher opta pela gravidez como meio de proteção e segurança contra possíveis agressões:

Às vezes a própria mulher engravida para ter uma segurança durante 9 meses, que não irá apanhar tanto do companheiro (ACS 1-GF1).

Este discurso revela o desespero da mulher que muitas vezes se sujeita a consequências gravíssimas para sua vida como alternativa a sua segurança, ainda que esta seja garantida por um curto período de tempo. Outras consequências também devem ser consideradas, como por exemplo, o nascimento de uma criança em um contexto de agressividade, assim como a interferência dessa violência nas escolhas de saúde reprodutiva da mulher. Neste sentido, o que significa a mulher precisar engravidar para não apanhar? A gravidez seria um meio de proteção? Nesta perspectiva, a reflexão de tais questionamentos pode contribuir para a compreensão do sofrimento da mulher, bem como sua sujeição a marcas tão profundas e consequências irreparáveis para sua vida, na tentativa de se proteger.

Segundo as agentes, o medo de retaliação desponta como uma das principais razões que levam as mulheres a não fazerem a denúncia. Logo, entendem que a realização da denúncia deveria vir acompanhada do acolhimento dessa mulher em uma casa abrigo. No entanto, apontam que nem sempre a mulher está preparada ou aceita sair de casa:

Existe um abrigo, mas a mulher nunca pensa em ir para lá. É complicado né, a mulher vai pra "Casa Sol" e o homem fica bonito, lindo, na casa, né (ACS 24GF5).

Segundo a policial da Delegacia de Mulher do município de Jundiaí, 90\% das mulheres recorrem a Medida Protetiva de Urgência e não aceitam o acolhimento em casa abrigo.

De acordo com a psicóloga da "Casa Sol", toda mulher em situação de violência doméstica e ameaça de morte, sem redes de apoio no município, pode solicitar o acolhimento em casa abrigo. Afirma que o encaminhamento pode ser realizado pela Delegacia da Mulher, pela Defensoria Pública e pela Promotoria. 
Em média, a "Casa Sol" recebe 3 casos de mulheres por mês e seu espaço físico, com dois quartos, quatro beliches e dois berços, comporta a demanda de acolhimentos. O serviço é direcionado às mulheres adultas e seus dependentes e às adolescentes com filhos. Em 2013, acolheram 31 mulheres, maior índice de acolhimento desde 2006. O número de crianças também é elevado, normalmente na faixa etária de 5 a 11 anos, alcançando seu maior índice em 2017, com 56 crianças.

Segundo a psicóloga da "Casa Sol", as mulheres abrigadas contam com o apoio e o suporte de uma equipe de profissionais, que tomam as medidas cabíveis para que esta mulher tenha condições de retomar sua vida. Menciona que o período de permanência proposto é de 120 dias, com a possibilidade de alterações, se necessário.

Para a assistente social do NASF, apesar da existência de uma casa abrigo no município, conhecida como "Casa Sol", que acolhe a mulher ameaçada e seus dependentes, a profissional entende que tal recurso não é suficiente para proteger a mulher, considerando que essa, ao sair da casa de acolhimento, retorne para o mesmo ambiente de conhecimento e muitas vezes de acesso do agressor.

Para as agentes, apesar da existência de uma casa abrigo, nem sempre as mulheres em situação de violência aderem a essa alternativa. A permanência da mulher em sua casa, no entanto, implica na repetição do ciclo de violência, embora a sua remoção temporária e retorno posterior possam de igual modo perpetuar esse ciclo. Assim, a recusa da mulher pelo abrigo pode estar associada ao desejo de organizar a família, a expectativa de mudança desse companheiro ou ao incomodo e inconveniente de mudar para um espaço, o qual não lhe seja familiar.

Outro ponto a considerar é a ausência de percepção da mulher quanto à violência sofrida, ou ainda a falta de discernimento sobre a situação, acompanhada do sentimento de vergonha, dificultando a tomada de decisão dessa mulher:

A mulher ela tem a percepção que está sofrendo a violência, mas como vítima ela está paralisada, como uma pessoa doente (ACS 3-GF1).

Para NOBREGA e MIRANDA (2013), a condição de vítima inicialmente atribuída à mulher pode ser substituída pela expressão "em situação de violência". Essa mudança propositiva teve como finalidade destacar o processo de superação da mulher, desde a vulnerabilidade até a resiliência. Neste sentido, a mulher deixa de ser sujeito passivo para ser sujeito ativo na relação. 
De certo modo, as agentes parecem oscilar entre a responsabilização da mulher pela ruptura do ciclo de violência e a condição de vítima, passiva, paralisada e doente. Segundo DEBERT e GREGORI (2008), as duas perspectivas ao extremo podem ser perigosas. Por um lado, a crítica a vitimização, que enxerga a mulher como vítima passiva da dominação masculina, e por outro, a mulher capaz de desenvolver atitudes adequadas que favoreçam a libertação das práticas discriminatórias, podendo incorrer na armadilha de transformar a violência, o poder e o conflito em problemas como falta de confiança e autoestima.

Assim, tanto o processo de conscientização como o empoderamento dessa mulher tornam-se necessários para o enfrentamento da violência, uma vez que, apenas com a identificação do problema e reconhecimento de sua real situação é possível à mulher usufruir das políticas e dos direitos a elas conferidos:

As mulheres não vão buscar a proteção contra a violência se elas não sabem o que é violência. Não sabem que tipo de violência elas estão sofrendo. Se você não sabe que aquilo que você tá sofrendo é uma violência, como você vai buscar seus direitos, como você vai recorrer à Lei Maria da Penha ou qualquer outro tipo de proteção? (ACS 13-GF3).

\subsubsection{Legislação}

Para os profissionais da rede de assistência, a existência da Lei Maria da Penha já é de conhecimento da maioria das mulheres, quer seja pela divulgação midiática, pelo disque denúncia ou pelos panfletos e literatura disponibilizada nos serviços de saúde. Apontam, entretanto, que apesar do conhecimento da Lei Maria da Penha, as mulheres não têm consciência de todos os direitos garantidos por Lei e não sabem como se beneficiar da mesma. Essas variáveis, porventura, podem estar relacionadas à baixa credibilidade na Lei Maria da Penha. Neste sentido, as agentes comunitárias assinalam que a Lei Maria da Penha foi resolutiva a princípio, quando foi sancionada, porém hoje, sua credibilidade já não é mais a mesma:

Quando foi lançada, por dois anos funcionou que era uma beleza. Hoje em dia virou uma lei normal, ninguém mais põe crédito nessa lei (ACS 13-GF3).

$A$ "medida preventiva" foi rígida no começo (ACS 12-GF3).

Eu posso dizer que essa lei não existe e não funciona por experiência própria. Meu pai me ameaçou de morte na frente da delegada. Ela insistiu para que eu fizesse o B.O., porque com o B.O. ela poderia me proteger. Ela disse: "trezentos metros você não pode chegar perto dela”. Já faz sete anos esse ocorrido e nada aconteceu, 
nenhum processo, nenhuma intimação para comparecer ao Fórum. Então morreu ali. A lei brasileira ela deixa muito a desejar. No meu caso eu já sabia, e eu sabia bem como me defender dele, mas e aí se não fosse o meu pai? Por isso que tem um monte de mulher que vai na delegacia e depois é morta (ACS 6-GF2).

No relato das agentes é possível perceber a baixa credibilidade da Lei Maria da Penha, bem como da Medida Protetiva de Urgência. Parte das agentes, por sua vez, defende a ineficiência dessa Lei, seja por experiência própria ou pela recorrência de homicídios femininos com a Medida Protetiva de Urgência. Segundo a psicóloga do Ambulatório de Saúde da Mulher, a impunidade do agressor é evidenciada mesmo quando há comprovação de violência. Menciona casos em que a Medida Protetiva foi concedida e outros casos de gravidade similar ou pior, em que a mesma não foi autorizada. Neste sentido, é interessante refletir sobre a expressão utilizada pelas agentes quanto a Lei Maria da Penha: "Hoje em dia virou uma lei normal, ninguém mais põe crédito" (ACS 13-GF3). O que seria uma lei normal? Neste discurso, as agentes estão sinalizando o descrédito não apenas na Lei Maria da Penha, mas também nas leis brasileiras de modo geral. Nesta perspectiva, verifica-se que as leis não possuem mais valor e estão totalmente banalizadas. Logo, o "normal", corriqueiro e esperado é a ausência de resolutividade das leis.

De acordo com a assistente social do NASF, a divulgação midiática dos casos de mulheres assassinadas com a Medida Protetiva desperta insegurança quanto à credibilidade $\mathrm{e}$ os direitos garantidos pela Lei Maria da Penha. Para as agentes, entretanto, as notícias veiculadas pela mídia apenas confirmam a ineficiência dessa Lei:

Porque assim, a gente ouve na televisão que a mulher tinha não sei quantos B.O. e a mulher morreu. O cara matou a mulher. Aí fala ela tinha três, quatro B.O., tinha medida protetiva, mesmo assim o cara matou. Ele era pra tá preso, não era pra tá solto. Não tem nada de medida protetiva, porque medida protetiva não funciona. $O$ cara quer matar, ele vai lá e mata. Ele teria que tá preso, não agrediu? Então fica preso (ACS 24-GF5).

Dá a impressão que na prática não é bem tudo aquilo que se fala, entende. Daquilo que eu já ouvi, eu não sei mais profundamente, mas dá impressão que foi "só um auê muito grande" em cima disso [Lei Maria da Penha], ah que as mulheres vão ter essa proteção, essa coisa, essa lei, mas assim mesmo, são tantos os casos de violência, cada momento, por dia, sei lá quantos acontecem até... (ACS 26- GF5).

Observa-se neste relato, o contraponto entre a ampla divulgação da Lei Maria da Penha e a baixa resolutividade das ações: "[...] dá a impressão que foi 'só um auê muito grande’ em cima disso, ah que as mulheres vão ter essa proteção, essa coisa, essa lei, mas 
assim mesmo, são tantos os casos de violência, cada momento, por dia..." (ACS 26- GF5). O discurso das agentes denota a popularidade da Lei Maria da Penha em contrapartida ao descrédito de sua efetividade, já que o índice de violência, apontado inclusive pela mídia, é cada vez mais crescente.

Para os profissionais da rede de assistência, a Lei Maria da Penha e a Medida Protetiva apresentam uma efetividade parcial. De acordo com a médica da USF Vila Marlene, a Lei existe para intimidar e limitar a ação do agressor, porém, não garante plena segurança. Para o médico da USF Santa Gertrudes, "a Lei pode até punir o cara, mas não vai proteger contra o principal que é a vida delas. Afinal, quando o cara quer, ele vai lá e mata”. Dessa forma, a impunidade do agressor e o medo de retaliação levam muitas mulheres a não fazerem a denúncia:

Você vai pra delegacia pra fazer um boletim de ocorrência, mas e dentro da sua casa depois? É por isso que acontece de muitas mulheres que fazem boletim de ocorrência essas coisas, os maridos matarem, por quê? Porque não tem essa segurança. E muitas acabam não fazendo o boletim e não falando nada pra ninguém por medo. A falta de segurança faz elas se esconderem (ACS 11-GF3). Têm casos [de mulheres em situação de violência] que foram resolvidos [pela Lei Maria da Penha], mas eu olhei e vi a impunidade. Independente de ter Lei Maria da Penha, se essa moça [charge - Apêndice 3] continuar fazendo B.O. e ninguém fazer nada, ela vai morrer. Vai além da Maria da Penha isso daqui. Tapinha passa batido, mas depois que mata, não tem mais jeito (ACS 17- GF4).

Neste relato, as agentes apontam para a impunidade do agressor, bem como para a falta de proteção e segurança da mulher ao prestar queixa na delegacia. Afinal, a realização do boletim de ocorrência implica em risco de retaliação. Assim, apresenta-se perante a mulher a difícil decisão em realizar ou não o boletim de ocorrência. Vale ressaltar, que em ambas as situações a mulher encontra-se vulnerável e sujeita a possíveis agressões.

Segundo a delegada de polícia do município de Jundiaí, atualmente não é mais possível fazer o boletim de ocorrência e retirar a queixa. Apesar da polêmica em torno desse assunto, a profissional de Segurança Pública defende que se a mulher tem a possibilidade de retirar a queixa, ela procura a delegacia com maior facilidade e nesse contato inicial o profissional pode ajudá-la de alguma maneira, seja por meio da escuta psicológica, do apoio da assistente social, assim como das informações sobre os serviços disponíveis em rede e dos direitos garantidos por Lei.

É interessante refletir quanto à possibilidade anterior que a mulher possuía em retirar a queixa. De acordo com a delegada de polícia, essa alternativa favorecia o acesso à delegacia, 
contribuindo para o auxílio e assistência à mulher em situação de violência. Segundo as agentes comunitárias, muitas dessas mulheres se silenciam e escondem a vivência de violência pelo medo e pela falta de segurança. Neste contexto, a impossibilidade da mulher em retirar a queixa desfavorece a procura por ajuda e reforça a invisibilidade da violência. Para as agentes, a realização do boletim de ocorrência implica no acolhimento imediato dessa mulher em uma casa abrigo:

Se a mulher faz a denúncia, ela não pode voltar pra casa, porque esse negócio de "300 metros longe de você", não funciona (ACS 6- GF2).

E outra coisa, não tem um policial pra cada mulher (ACS 7-GF2).

Neste relato, as agentes apontam para a fragilidade dos serviços de Segurança Pública e a deficiência do Judiciário em assegurar e cumprir os direitos previstos em Lei. Em virtude desse sistema precário, o qual deveria proteger e garantir os direitos da mulher, mas, reiteradamente, não corresponde a suas atribuições, a mulher por vezes não visualiza alternativa a não ser a permanência no relacionamento abusivo. Por esta razão, as agentes enfatizam o acolhimento da mulher em uma casa abrigo sem o retorno da mesma para o local de residência.

Dentre as fragilidades dos serviços de Segurança Pública, as agentes comunitárias destacam a falta de sigilo nas delegacias e o despreparo dos profissionais para lidar com a demanda de violência contra a mulher:

Eu acreditava [na efetividade da Lei Maria da Penha] antes de trabalhar aqui, mas depois que eu soube que todo mundo sabe o nome de quem denuncia, que não há o sigilo, as meninas falaram, a polícia chega aqui dizendo o nome da pessoa que telefonou, daí eu já não sei mais agora (ACS 3-GF1).

Se fosse sigiloso, não deveria pedir nem o nome da pessoa que está ligando. Você liga lá para fazer uma denúncia, daí eles falam: "fala seu nome”, "não, mas eu não quero", "mas precisa só para constar aqui" (ACS 1- GF1).

A falta de sigilo e ética dos profissionais de Segurança Pública produz um efeito negativo tanto para as mulheres em situação de violência como para os demais profissionais, familiares, vizinhos ou conhecidos, que muitas vezes desejam fazer uma denúncia anônima, porém, correm o risco de serem ameaçados ou sofrerem algum tipo de retaliação. Como consequência, agrava-se o descrédito na Lei Maria da Penha. 
De acordo com a médica da USF Vila Marlene, a Lei Maria da Penha pode até ser efetiva, entretanto, questiona a continuidade desse benefício, o período de proteção à mulher e como esse agressor será reabilitado ou absorvido por este sistema. Em suas considerações, aponta para a compreensão dos profissionais de saúde quanto à existência de um serviço que acolhe a denúncia da mulher, porém observa a falta de clareza dos profissionais a respeito do pós-denúncia. Pergunta-se: O sigilo será mantido? Quem será protegido ou exposto em uma denúncia como esta? Quais serão as medidas e penalidades do agressor?

Para o Coordenador do Consultório de Rua, a Lei existe para proteger e corrigir o desvio social. Entende que a Lei Maria da Penha está inserida nas políticas afirmativas, e, no futuro, quando a sociedade avançar, não será mais necessária. Em sua perspectiva, se a Lei contra a tortura de outro ser humano fosse respeitada, então não haveria uma Lei específica às mulheres. Dessa forma, não acredita em direitos ou políticas isoladas, pensa no processo de cidadania e garantia de direitos a todos, não apenas a mulher, mas também as crianças, adolescentes, idosos ou homens. Neste sentido, as agentes questionam a existência de tantas leis assim como uma Lei direcionada às mulheres:

Um país com muitas leis é para pessoas mal-educadas, sem respeito. Existem países da Europa que não precisam de tantas leis, pois a cultura é diferente (ACS 9-GF2). $O$ que eu já vi de mulher batendo em marido. Acho que os homens conhecem mais essa lei do que as mulheres, porque eles ficam quietinhos com a Lei Maria da Penha. Tem que ter a Lei do Chico João também (ACS 6-GF2).

Observa-se no discurso das agentes a desvalorização da Lei Maria da Penha, na qual entendem como necessária a um país atrasado: “um país com muitas leis é para pessoas mal educadas e sem respeito" (ACS 9- GF2). Assim, criticam a existência de uma lei específica as mulheres e sugerem a criação da Lei do "Chico João". Neste sentido, vale ressaltar a possível aplicação da Lei Maria da Penha para proteger homens vítimas de violência doméstica pelo princípio da Isonomia e por analogia in bonam partem. De acordo com o juiz Dr. Mário Roberto Kono de Oliveira, do Juizado Especial Criminal Unificado de Cuiabá, não havendo lei similar para proteção do homem, as medidas protetivas de urgência da Lei Maria da Penha poderão ser aplicadas quando provado que este tenha sofrido agressões e ameaças pela companheira. Observa-se, no entanto, a falta de consenso quanto a esta questão. Para Iriny Lopes, ex- ministra da Secretaria Especial de Políticas para as Mulheres no Brasil, a aplicação da Lei Maria da Penha aos homens é inadequada, pois quando este é agredido não se deve ao fato de ser homem, mas por outras razões. Já no caso da mulher, essa é agredida por ser 
mulher. Dessa forma compreende que o homem deve ser protegido pela legislação comum, de acordo com o Código Penal. Nesta perspectiva, a Lei $n^{\circ} 12.403 / 11$ que alterou o artigo 319 do Código de Processo Penal, pode vir a suprir essa carência pelas medidas cautelares, quando o crime de violência doméstica for praticado contra qualquer pessoa que não seja do gênero feminino (NASCIMENTO, 2013).

De fato, a lei precisa garantir o direito de todas as pessoas, entretanto, não há como negar que existe uma desigualdade entre os gêneros e que alguns, neste caso as mulheres, são afetadas de forma desigual pela violência. Neste sentido, questiona-se: como garantir a igualdade de direitos? Não seria necessário pensar no princípio de equidade do SUS? "Tratar os desiguais na medida de sua desigualdade?" É interessante ainda refletir se de fato o avanço da sociedade representaria o fim da Lei Maria da Penha, considerando a supremacia da cultura machista, os preconceitos e as desigualdades entre homens e mulheres arraigados e cultivados ao longo da história. Haveria como desconsiderar ou ignorar esse histórico de violências contra a mulher, suas marcas e consequências tanto para o presente como para as futuras gerações?

\subsection{ATENÇÃO À VIOLÊNCIA NOS SERVIÇOS DE SAÚdE E NA REDE DE ASSISTÊNCIA}

Dentre os serviços de assistência a mulher em situação de violência, as agentes comunitárias destacam o apoio e suporte das unidades de saúde da família em parceria com o NASF. A delegacia de polícia, embora muito criticada pela abordagem dos profissionais e também pela baixa resolutividade das ações, é apontada com frequência no relato das agentes como possibilidade de ajuda. Outros serviços como o Ambulatório de Saúde da Mulher para casos de violência sexual e a casa abrigo, conhecida como "Casa Sol”, são mencionados.

Em resposta a charge (Apêndice 3) apresentada como estímulo inicial para a discussão, as agentes observam a ineficiência dos serviços de Segurança Pública. Nessa charge, a mulher sai com o B.O. da delegacia, toda espancada e recebe um tapinha nas costas da policial que diz: "liga não minha filha, isso é normal". Neste sentido, as agentes apontam para a impunidade dos inúmeros casos de violência arquivados e sem repercussão: 
Eu vejo impunidade, só impunidade [charge-Apêndice 3], não adianta a mulher chegar arrebentada, sabe que não vai acontecer nada, fazer um, dois, dez, cinquenta B.O. Depois que morreu não adianta mais nada. Fez o B.O. aqui, ela fez o B.O., ela foi procurar, ela não se acovardou. Mas eu vou ser morta, que nem aquela moça que foi queimada aqui perto, ela fez mil vezes o B.O. lá, pediu "pelo amor de Deus ele vai me matar" e matou mesmo. Depois que matou, depois que morreu, e não foi um caso só, mas esse caso era mais próximo a mim por isso que eu sei, depois eles foram ver que tinha um monte de B.O. É o Satanás. Eles arquivam tudo, ninguém faz nada. Não pode chegar tantos metros da casa da pessoa, vai lá mata, foge, foge do flagrante e vive feliz em outro lugar e já era. Eu tenho um assassinato em família aqui também, que tá livre até hoje. Nem era daqui, era de uma cidade de longe, foi pra longe, matou, o cara sumiu por 24 horas, voltou se apresentou, tá lindo e maravilhoso e não deu em nada. Não foi preso, nada. Primeira vez, não foi pego em flagrante... Réu primário, teve cobertura do pessoal lá. Uma morte que não dá pra entender, porque a pessoa não conhecia ninguém, meu cunhado foi pra lá e simplesmente não voltou, saiu pra pescar e não voltou, porque ele paquerou não sei quem lá. Os filhos nem sabe até hoje. Mas é uma impunidade total e não é só no caso da violência do lar, feminina... A violência em geral [pausa], geral (ACS 17- GF4).

As agentes revelam o despreparo dos profissionais de Segurança Pública em lidarem com situações de violência contra a mulher. Não raramente, o pedido de socorro da mulher é negligenciado e mesmo com a realização do boletim de ocorrência, a mulher permanece desprotegida. É interessante ressaltar que a impunidade é percebida pelas agentes não apenas para os casos de violência contra a mulher, mas para a violência em geral. Outro ponto questionável é o tratamento recebido pelas mulheres na delegacia. Assim como na charge, em que a violência sofrida pela mulher é banalizada, as agentes enfatizam que muitas vezes as mulheres que procuram ajuda são ridicularizadas nas delegacias:

[...] porque se acontecer esse caso aqui, coitada né! [risos], porque hoje em dia é assim mesmo, eles [profissionais de Segurança Pública] tiram sarro da cara, porque eles falam "vai repetir de novo e daqui a pouco já tá de volta aqui" [delegacia] né. Para eles tanto faz como tanto fez (ACS 23-GF5).

Neste relato, o descrédito dos profissionais de Segurança Pública pelo pedido de socorro das mulheres é evidente. De acordo com a psicóloga do Ambulatório de Saúde da Mulher, muitas mulheres resistem em procurar a delegacia pela falta de efetividade da Lei ou ainda, pelo tratamento preconceituoso dos profissionais, que não raramente, responsabilizam a mulher pela violência sofrida. Para as agentes, a falta de acolhimento, ética e sigilo nas delegacias já configuram uma forma de violência contra a mulher: 
[...] que nem essa policial aqui [charge- Apêndice 3], ela não teve ética né, vendo a mulher toda quebrada, com o B.O. na mão, "liga não minha filha, isso é normal". Então já é uma falta de ética contra a mulher né. Será que ela parou para pensar que [pausa], o trabalho dela ali é para acolher, tudo bem ela apanhou, ela foi espancada, brigou com o marido, talvez ela esteja de saco cheio de ficar ouvindo isso a todo momento, mas [pausa] cada vida é uma vida, cada história é uma história, então ela deveria acolher melhor essa mulher. E de repente ela sai de uma delegacia totalmente frustrada, ela entrou deprimida e vai querer sair correndo. Então isso também é uma violência (ACS 15-GF3).

As agentes apontam para a singularidade da queixa da mulher, mesmo que essa já seja de conhecimento do profissional, entendem que a escuta, o acolhimento e o cuidado devem ocorrer levando-se em consideração a subjetividade da mesma. As agentes criticam não apenas a abordagem dos profissionais às mulheres em situação de violência como também ao denunciante:

Era anônima [denúncia], mesmo assim a moça queria saber o nome dela [da gerente]. O nome, cor de cabelo, outras coisas... É dificultoso. Nossa é pra dificultar as coisas. Se é urgente, como que tem toda essa coisa... (ACS 24-GF5).

Você passa o que tá se passando com a outra pessoa, mas [pausa] saber de mim, vai bater na minha casa lá para saber o que tá acontecendo? Meio complicado esse negócio (ACS 23-GF5).

Nota-se o descontentamento das agentes com relação à burocracia dos serviços, ao detalhar uma série de informações em um momento emergencial e inquirir inadequadamente a identificação do denunciante. Além disso, o medo do pós-denúncia fica evidente no relato das agentes. Assim, a insegurança quanto as possíveis consequências ao denunciante, diminui a possibilidade de ajuda à mulher, pois, muitos profissionais, vizinhos, familiares e conhecidos preferem não se expor em tais circunstâncias.

De acordo com a gerente da USF Vila Ana, o pedido de socorro de uma pessoa nunca pode ser negligenciado. Relata caso marcante em que a usuária fez o pedido de socorro e os profissionais de saúde, inclusive a própria gerente, consideraram exagero. No mesmo dia, a mulher foi morta pelo companheiro. Dentre outras razões, a gerente acredita que a violência seja negligenciada pelos profissionais por conta de outras demandas emergenciais. Revela também a frustração do profissional em lidar com a violência, por se tratar de uma demanda de saúde mental, em que não há soluções rápidas: “a gente tá com uma dor, toma um remédio, aquilo resolveu e acabou". Agora essa situação [de violência] envolve outras questões como estrutura familiar e o contexto social. 
Concernente às observações da pesquisadora nas unidades de saúde da família, verificou-se que a denúncia é feita pelos gerentes. Os agentes trazem os casos confirmados ou de suspeita para a discussão em reunião, mas quem faz a notificação e a denúncia é o próprio gerente. Nesse aspecto, a postura adotada pelos gerentes influencia diretamente na postura dos agentes comunitários de saúde. Observou-se também maior grau de conscientização, compreensão e interesse dos agentes pelos casos de violência, nas unidades em que os gerentes apresentavam maior grau de informação sobre a temática, comprometimento e articulação com os serviços da rede.

Segundo as agentes comunitárias, a violência doméstica contra a mulher dificilmente se apresenta como demanda direta nos serviços de saúde. Os casos de conhecimento das agentes, usualmente são episódios de violência ocorridos no passado, ou ainda, episódios no presente por meio de encaminhamento do CREAS ou do abrigo de mulheres:

\begin{abstract}
A gente fica mais ou menos sabendo, quando vem pra gente em caso social, tipo assim, que foi parar na delegacia, a gente não ficou sabendo daí foi pro CREAS ou chegou no abrigo e aí vem pra gente fazer visita, pra gente ver o que está acontecendo, dai a gente participa de algumas reuniões. Eu nunca tive que chegar em visita e ver alguma paciente minha com olho roxo, machucada, isso nunca aconteceu (ACS 24-GF5).

O que tem e já aconteceu comigo, casos de pessoas que, de ter já falado que quando vivia com o marido e isso já fazia muito tempo, que sofria violência, porque não era um bom marido, não era um bom pai e chegou a ser agredida, tudo. Mas isso daí muito tempo antes já tinha acontecido, ela já tinha se separado, já tava livre, em caso até de ela já era viúva, então saiu da situação né (ACS 26-GF5).
\end{abstract}

As agentes apontam que os episódios de violência costumam ser relatados em consulta médica, porém não como queixa primária. De acordo com a psicóloga do NASF, normalmente a demanda de violência contra a mulher chega como queixa secundária e é descoberta nos bastidores, quase como uma fofoca. Aponta que os próprios profissionais de saúde responsabilizam a mulher pela violência sofrida e atribuem a esta um comportamento de passividade e submissão. Segundo a gerente da USF Vila Marlene, muitas vezes o profissional não compreende que a mulher está doente, em sofrimento psíquico, e não consegue se desvencilhar da situação. Para esse profissional, a mulher possui autonomia para sair da situação de violência, logo, não se deve interferir. Para a psicóloga do NASF, entretanto, essa compreensão não se aplica a violência contra a criança ou a violência contra o idoso. Entende que a violência contra a mulher é muito negligenciada na rede, em comparação a violência contra a criança, além de não se manifestar como demanda de 
capacitação. Neste sentido, as próprias agentes comunitárias identificam entre os profissionais de saúde a percepção da violência como questão secundária aos serviços:

[...] Eu achei um absurdo a fala do colega [profissional de saúde em reunião de matriciamento] de deixar a violência para ser tratada depois, no caso em que toda a vida dela está a violência. Tudo o que acontece com ela é a violência. Eu achei um escândalo. Machista. [...] Essa fala dele de deixar a violência como sendo a última coisa a ser tratada em um caso daquele ali da mulher... E outra coisa, aquela profissional que estava junto com ele, eu não sei o que ela é [enfermeira], mas como mulher ela concordou. Eu fiquei assim muito... para mim seria a primeira coisa a ser tratada né, e a fala também de querer consertar o casamento de quinze anos primeiro para o cara não bater nela, para depois resolver todo o problema da violência. Até serem tratados todos esses problemas no caso, ela já morreu (ACS 3GF1).

Nota-se no relato das agentes que a banalização da violência e reprodução dos preconceitos a mulher não se encontram apenas entre os profissionais de Segurança Pública, mas também entre os próprios profissionais de saúde da rede de assistência:

Por que que fala que mulher que apanha tá que nem mulher de bandido? Por que mulher de bandido? Hum? É assim que as pessoas tratam as mulheres que são violentadas dentro de casa, é que nem mulher de bandido, adora apanhar. É preconceito. É preconceito como é com negro, com deficiente, é preconceito (ACS 24- GF5).

E a gente nem entrou no caso das mulheres transexuais. A gente nem entrou nesse caso. $O$ respeito por elas, falta um esclarecimento do que são os transexuais, as mulheres que são gays, entendeu? Qual o respeito? São mulheres. Então existe muita violência dentro do sistema de saúde e não é violência contra você, mas é a risada, é a maneira que fala, entendeu? São as referências que tem (ACS 3-GF1).

As agentes criticam as representações sociais atribuídas às mulheres violentadas, bem como os preconceitos e estigmas aos grupos vulneráveis e desfavorecidos, dentre eles: mulheres, negros, deficientes e transexuais.

Para Robert Stoller, em seu livro "Sex and Gender" (1968), o "sentimento de ser mulher" ou o "sentimento de ser homem" referente à identidade de gênero é mais importante do que as características anatômicas, $\log$, o gênero não corresponde necessariamente ao sexo, pois, pessoas com anatomia sexual feminina sentiam-se homens, e vice-versa (apud PEDRO, 2005).

Relembrando PEDRO (2005), durante o movimento feminista de segunda onda, a própria categoria "Mulher" passou a ser substituída pela categoria "Mulheres", justamente por 
não ser representativa dos vários tipos de mulheres, como por exemplo, negras, índias, mestiças, pobres, trabalhadoras que reivindicavam a diferença dentro da diferença.

Retomando o argumento de LOURO (2014), não existe a mulher, mas várias mulheres, com características diferentes entre si. Sendo assim, levando-se em consideração as diferentes formas de feminilidade e masculinidade que se constituem socialmente, torna-se possível compreendê-las e incluí-las.

Em seu discurso, as agentes fazem um recorte da sociedade quando retratam que os profissionais de saúde não estão preparados para lidar com a diversidade e pluralidade desses grupos, além da percepção da violência velada entre os profissionais, que refletem os preconceitos de uma sociedade apegada às tradições e resistente às mudanças.

As próprias agentes ou demais profissionais de saúde, muitas vezes, apresentam trajetórias de violência. A gerente da USF Vila Ana relata caso de ex-agente comunitária em que o marido era etilista e essa sofria constantes agressões, apresentando faltas regulares no serviço e marcas corporais evidentes. Mesmo assim, a agente não falava a respeito e inventava desculpas para não expor a situação. Foi necessária uma conversa em particular para a profissional se confidencializar. A gerente, que vivenciou histórico pessoal de violência no passado e participou de grupo de mulheres para familiares de etilistas, acredita que a agente tenha se identificado com sua experiência. Outro caso semelhante de ex-agente comunitária foi apontado pela gerente da USF Santa Gertrudes. Segundo a gestora, "mesmo para o próprio profissional de saúde, com orientação, a situação [de violência] é difícil e delicada, quando a pessoa está vivenciando o problema".

É importante considerar as vivências de violência das agentes e como essas profissionais são sofridas. Por serem da comunidade e compartilharem das mesmas experiências, muitas vezes estão desacreditadas da Lei, da polícia e da delegacia. Outras vezes, entendem que a demanda de violência não compete aos serviços de saúde:

Sem contar nossas atribuições [dos agentes comunitários] né, que a gente é da saúde, problema social é problema social... Tem coisas que você não pode ficar abraçando, porque você já não dá conta do que você tem pra fazer. O tuberculoso tem que tá assistido todo dia pra tomar o remedinho e aí é nós. Tudo é nós, tudo, tudo. Tudo é nós. Então chega um certo ponto que você se isenta. Você percebe é uma assistente social que vai ter que resolver isso [casos de violência contra a mulher], não é o agente de saúde. [...] Sabe as consequências dessa violência é claro que vai terminar na saúde, mas o início disso tudo é um problema social, eu acho. Totalmente social (ACS 17- GF4). 
Segundo BATISTA (2005), em geral, os profissionais de saúde não identificam a violência como problema de saúde e, quando o fazem, negligenciam o registro da queixa em prontuário. SCHRAIBER e D’OLIVEIRA (1999) apontam que 50\% a 60\% das mulheres de um estudo realizado em um serviço de atenção primária de São Paulo mencionaram ter sofrido algum episódio de violência, porém apenas $10 \%$ dos prontuários constavam o registro dos casos. Devido a essa racionalidade biomédica de intervenção, que entende a doença como alteração anatomopatológica, a demanda de violência tende a ser desconsiderada pelos serviços de saúde. Com exceção dos casos de lesão corporal, a violência é compreendida como queixa de ordem social ou psicológica.

Observa-se no discurso das agentes a sobrecarga de atividades e responsabilidades a que estão submetidas. Em virtude da racionalidade biomédica de intervenção, a qual os profissionais de saúde são socializados, as agentes entendem a violência como um problema de cunho social e com consequências à saúde, porém, desconsideram os aspectos da prevenção descritos no item VII de suas atribuições:

Desenvolver atividades de promoção da saúde, de prevenção das doenças e agravos e de vigilância à saúde, por meio de visitas domiciliares e de ações educativas individuais e coletivas nos domicílios e na comunidade [...], mantendo a equipe informada principalmente a respeito das situações de risco (MINISTÉRIO DA SAÚDE, 2012).

A compreensão da violência pelas agentes como um problema exclusivamente social, bem como a falta de interesse e acolhimento dos profissionais da equipe pela demanda de violência levam a questionar até que ponto, em termos de ações no território, esses profissionais poderão contribuir para ajudar essas mulheres em situação de violência.

Vale ressaltar, entretanto, que parte das agentes comunitárias entende a demanda de violência não apenas como consequência, mas como um problema inerente aos serviços de saúde:

É um problema de saúde, porque mexe com o psicológico (ACS 5-GF1).

A mulher, os filhos, tudo fica doente, até o infeliz do marido dela. Depois vem aí com cirrose pra tratar (ACS 7- GF2).

Para os profissionais das equipes de ESF do município de Jundiaí, a violência nem sempre é considerada por todos como um problema de saúde. Alguns consideram seu produto 
como uma demanda de saúde, porém, não fazem menção aos aspectos da prevenção. Em virtude da concepção dos profissionais em não considerar muitas vezes a violência como uma demanda de saúde ou uma demanda emergencial, ou ainda a compreensão quanto à autonomia da mulher e o respeito à privacidade do casal, destaca-se a importância da revisão dos currículos de formação e a capacitação não apenas dos agentes comunitários, mas de todos os profissionais da rede de assistência.

Salienta-se também a relevância de formação e capacitação do profissional de saúde referente à abordagem a ser utilizada para os casos de violência. Neste sentido, as agentes ressaltam a dificuldade do profissional em lidar com a situação de violência, quer seja por resistência da mulher em receber ajuda, quer seja pelo medo do profissional a exposição ou retaliação:

\footnotetext{
Às vezes você não consegue se aproximar da pessoa por ela ser assim [agressiva]. Você vê que a pessoa precisa de ajuda, você quer ajudar, mas a pessoa que mais precisa num [pausa]... Tem aquela resistência, não se permite ser ajudada (ACS 11GF3).

[...] Eu senti assim, muitas vezes vontade de chegar perto dela, conversar, como você está? O que foi que aconteceu? Você pode contar um pouquinho pra mim? Eu posso te ajudar? Mas eu tinha medo porque as pessoas diziam: "não vai não, porque ela é agressiva. De repente você vai falar e ela vai te dar um soco" (ACS 15- GF3).
}

Observa-se no discurso das agentes, a percepção quanto à necessidade de cuidado ao usuário, assim como a disposição do profissional em ajudar. O medo de invadir o espaço do outro e sofrer algum tipo de represália, bem como a resistência da pessoa em receber ajuda desfavorecem, por sua vez, as ações das agentes comunitárias. Desse modo o vínculo entre o profissional de saúde e o usuário dos serviços torna-se fundamental para esta abordagem. Além disso, as agentes enfatizam a importância do cuidado humanizado, considerando as necessidades e particularidades individuais:

Eles falam tanto em humanização e a gente tá vendo isso se perdendo a cada momento, cada minuto essa humanização (ACS 12- GF3).

Você vê a Silvana quando chegou na unidade, moradora de rua, toda suja, fedendo, toda machucada, porque o namorado tinha batido nela. O que que nós fizemos, eu fui, acolhi, conversei, aí não tinha enfermeira, estavam só as auxiliares, elas foram, acolheram ela, deram um banho, uma correu na casa, buscou uma blusa, outra tinha não sei o que. Eu sei que ela saiu dali de dentro da unidade com o cabelo cortado, colocaram ela de baixo do chuveiro. Não, nós precisamos cuidar, não é falar que é isso. Isso é humanização, não sei se foi certo, se foi errado o que que aconteceu ali né, mas fizemos. Daí deu banho, demos umas cortadas no cabelo dela, ficou até bonita, toda limpinha. Aí foi lá no fundo, fizemos curativo, ela saiu toda enfaixada, toda de curativo. Veio fazer o curativo até cicatrizar, porque machucou a 
perna também né, o braço ficou ralado. Quando ela cicatrizou todinha as feridas dela, o corpo dela, ela sumiu de novo. Mas naquele momento ali, a gente acolheu né. Não é que na nossa unidade só tem perfeição, mas existe uns momentos né. Então isso assim, é muito, muito gratificante, porque tem que olhar pra ela como um humano né, como filha, criatura de Deus (ACS 15-GF3).

As agentes atribuem ao cuidado humanizado, à capacidade de se colocar no lugar do outro, de atender as necessidades emergenciais e garantir o suporte necessário para que essa pessoa tenha condições de se reerguer. Mesmo sem clareza do conceito de humanização, as agentes reproduzem em suas práticas uma das diretrizes da Política Nacional de Humanização, referente ao acolhimento do usuário. Essa diretriz preconiza, por sua vez, o reconhecimento das necessidades em saúde, bem como o acesso aos serviços por meio da escuta qualificada do profissional, o que possibilita a construção de relações de confiança, vínculo e compromisso (MINISTÉRIO DA SAÚDE, 2013). Vale ressaltar que o cuidado em saúde deve ocorrer de forma integral, permanente e continuada.

Segundo BATISTA (2005) lidar com a violência implica em ver e visibilizar os casos, acolhê-los e dar cuidados ou assistência. Observa que muitos casos são reconhecidos, porém se perdem no trajeto pela falta de acolhimento e assistência. Aponta que o acolhimento acontece de acordo com a disponibilidade pessoal de cada profissional. Já a assistência e cuidado são quase inexistentes nos serviços, dependendo de esforços individuais para buscar ajuda de serviços de referência ou mesmo de cuidado interno.

\subsubsection{Representações dos Agentes Comunitários sobre os Serviços de Saúde}

Mediante as observações da pesquisadora em campo e as conversas de apoio com os profissionais da rede de assistência e a realização dos grupos focais com as agentes comunitárias, verificou-se que a ficha de notificação raramente é preenchida nos serviços de saúde. A falta de clareza sobre sua finalidade, importância ou o próprio desinteresse do profissional são recorrentes. Além disso, a confusão entre notificação e denúncia, o detalhamento e extensão da ficha de notificação, bem como a falta de vínculo com o usuário, agravam a subnotificação dos casos de violência. Assim, a gerente da USF Vila Marlene aponta que não há como saber ao certo o número de casos de violência no município, o que 
prejudica a elaboração das ações pelas unidades de saúde, em especial das UBS tradicionais, que não contam com o apoio dos agentes comunitários de saúde.

Entre as agentes comunitárias, observa-se que mesmo havendo a compreensão de que a notificação se refere apenas a dados estatísticos voltados à Vigilância Epidemiológica, o medo da identificação, exposição e retaliação permanecem:

É como a gente fala, quem tem que fazer [a denúncia] é o paciente, porque depois a gente vai se expor e depois ele vem e fala que não está acontecendo. Ele desabafa com a gente, daí a gente vai e faz a denúncia e aí, por exemplo, chama o paciente, daí a gente se expõe e ele fala que não está acontecendo [a discussão era sobre a notificação] (ACS 5-GF1).

Em partes esse medo é justificável, pois, nos casos de violência contra a criança, adolescente e idoso, a notificação se desdobra em denúncia policial, o profissional é identificado e os respectivos conselhos, Conselho Tutelar ou Conselho do Idoso, são acionados:

[...] no caso de uma criança, às vezes você vê uma criança sendo maltratada, você traz o caso para unidade e daí aciona o Conselho Tutelar. Daí eles perguntam, quem presenciou? Ah o agente. Daí a gente passa o caso para unidade, mas a gente fala: "Ah doutora, eu moro no bairro, eu convivo, eu vejo a pessoa, dai eu vou me expor?” É complicado (ACS 1- GF1).

Por fazerem parte da comunidade, o medo de retaliação entre as agentes comunitárias é intensificado. Esse procedimento, no entanto, não ocorre nos casos de violência contra a mulher, pois, a notificação não implica na realização da denúncia pelo profissional:

Agora no caso da mulher é mais fácil, o medo é menor porque, a gente está mandando só para dados estatísticos, porque quem vai fazer todas as ocorrências é a mulher que tem empoderamento para fazer, nos outros casos não (ACS 3-GF1).

Nota-se que o medo de represália e quebra de sigilo tanto para a denúncia como para a notificação é comum e recorrente não apenas entre as agentes comunitárias, mas também entre os demais profissionais de saúde. De acordo com a enfermeira da USF Vila Ana, assim que entrou na unidade foi alertada e advertida quanto à realização dos relatórios e da notificação: "cuidado com o que você faz, pois, pode ocasionar alguma coisa". Todos os 
profissionais da unidade, inclusive as agentes comunitárias, tinham conhecimento do caso da enfermeira anterior, que foi ameaçada pela usuária e não permaneceu no serviço devido à quebra de sigilo de um relatório ao HU (Hospital Universitário). Segundo a gerente da USF Vila Ana, a moça era usuária de crack, estava grávida, havia tido um pré-natal complicado sem o devido acompanhamento e teria mencionado que não desejava a criança. Neste contexto, a criança foi retirada da mãe e levada a casa transitória, sendo alegado pelo Conselho Tutelar a realização de um relatório pela enfermeira da unidade.

Segundo a gerente da USF Santa Gertrudes, o medo da notificação está associado ao despreparo e a desinformação do profissional que não foi capacitado. Para a psicóloga do NASF, contudo, nos casos de violência contra a mulher, os profissionais compreendem que a notificação não se desdobra em uma denúncia policial, porém, já aconteceu da Vigilância Epidemiológica solicitar maiores informações do caso e pedir uma visita. Por esta razão, o medo de assinar pela unidade ou mesmo carimbar a ficha de notificação é geral, deixando os profissionais amedrontados e com receio de serem prejudicados.

Conforme as observações da pesquisadora em campo, as capacitações direcionadas a notificação das violências ocorrem de forma esporádica, espaçada e muitas vezes, devido à alta rotatividade dos profissionais, nem todos são capacitados. Outras vezes, esses treinamentos são voltados a um determinado grupo de profissionais, por exemplo, médicos e enfermeiros.

Dentre os serviços de saúde mencionados pelas agentes comunitárias a contribuir para o fortalecimento da mulher em situação de violência, as agentes destacam a participação do NASF nas Unidades de Saúde da Família. Ressaltam, entretanto, a falta de continuidade dessas ações, a rotatividade dos profissionais e a mudança de horários dos grupos como desmotivadores:

E pra mim, parte do fortalecimento da mulher é através da psicologia, para ela conseguir tomar as ações. Aí conseguir que ela seja autônoma, ai sim. Mas é uma coisa longa, nós não temos no serviço, muda, troca, não tem horário, a rotatividade, às vezes o próprio profissional não passa segurança pra você, não conversa com os agentes comunitários, porque a nossa fala é muda. [...] O NASF agora tem acompanhamento com a psicóloga, mas não tem continuidade. [...] tava mudando o NASF [a equipe de profissionais], a menina [profissional do NASF] não atendeu e desmarcou e mandou ela [usuária] embora. Eu levei seis anos para conseguir que ela [usuária] saísse de dentro de casa para vir em algum lugar participar, porque ela é uma pessoa depressiva, com vários problemas. Ela já não estava querendo fazer nada. Eu não vou conseguir fazer com que ela volte. Mais de seis anos [pausa], eu demorei pela primeira vez. Então a falta de continuidade dos trabalhos né... A justificação de troca do NASF para não dar continuidade aos trabalhos, porque um profissional age de um jeito, e outro age de outra maneira [pausa], nesse meio tempo paciente sumiu (ACS 3-GF1). 
Daí você marca o paciente e fala: vai no grupinho. Aí chega no dia o profissional não vem. Às vezes você marca com a psicóloga e vem a assistente social (ACS 1GF1).

As agentes comunitárias reconhecem a importância do suporte psicológico oferecido às mulheres em situação de violência por meio da equipe do NASF. Criticam, no entanto, a descontinuidade das ações pela rotatividade dos profissionais, o descomprometimento na prestação dos atendimentos e a mudança de horário das reuniões. Outro ponto em questão refere-se à realização dos grupos por profissionais de diferentes especializações. As agentes apontam que os usuários dos serviços com um nível socioeconômico mais elevado percebem a diferença nos atendimentos e questionam essa abordagem. Neste sentido, os próprios profissionais do NASF mencionam certo desconforto em desenvolver algumas temáticas que fogem a sua área de atuação.

As agentes observam que a abordagem grupal não atrai muitos adeptos por conta da exposição e proximidade entre os usuários. Em uma das unidades, inclusive, o atendimento prestado pelo NASF passou a ser individual:

O NASF, o psicólogo faz atendimentos individuais, porque o grupo aqui o psicólogo não deu certo (ACS 3-GF1).

Não tem como, porque você não vai contar um caso seu no meio de uma roda como a ACS 4 colocou que a comunidade se conhece, ah hoje meu marido bateu em mim. Você vai contar pra vizinha, dai "ah, bateu nela? Nossa, mas...” (ACS 1-GF1).

Tipo assim, chega a mãe chorando, porque o filho tá na droga e a mãe do traficante tá lá também (ACS 4- GF1).

Segundo a psicóloga do NASF, o tratamento individual dificilmente ocorre, pois, o NASF trabalha prioritariamente com o acolhimento e o grupo de escuta. Aponta, entretanto, que muitas vezes os próprios participantes se mobilizam e ajudam um ao outro, por meio dos discursos e experiências compartilhadas. Menciona ainda que em algumas situações, um atendimento pontual é suficiente, porém, outras vezes, a demanda é mais complexa, como nos casos de violência, que nem sempre o usuário se sente à vontade para falar. De acordo com a psicóloga do NASF, essas demandas permanecem no limbo, pois não se tratam de um sofrimento psíquico de ordem de CAPS, e em contrapartida, não são resolvidas apenas com os grupos de escuta. Aponta que esses casos de gravidade intermediária entre a atenção básica e a atenção especializada acabam sendo perdidos. Sendo assim, sugere a criação de um serviço 
intermediário, dentro da própria atenção básica, responsável pelas demandas de uma complexidade sociofamiliar, como é o caso da violência doméstica contra a mulher.

Neste sentido, vale mencionar a iniciativa da Faculdade de Medicina da USP pela criação de um serviço destinado à mediação de conflitos familiares difíceis (CONFAD) ${ }^{7}$. Localizado no Centro de Saúde Escola Samuel Barnsley Pessoa, na região do Butantã - São Paulo, esse serviço tem como finalidade oferecer à mulher em situação de violência uma escuta atenta e qualificada dos seus problemas, garantindo informações a respeito dos serviços que compõem a rede de assistência, além de apoiar a mulher no sentido da transformação da situação de violência, especialmente naquelas de cunho doméstico-familiar. No relato das agentes observa-se a necessidade de articulação dos serviços da rede e a continuidade da assistência para o atendimento às mulheres em situação de violência. Verifica-se, contudo, a impotência das agentes comunitárias em lidarem com demandas que exigem encaminhamento imediato, quer seja pelo desconhecimento dos serviços oferecidos em rede, quer seja pela inexistência de serviços que acolham e apoiem a mulher emergencialmente:

Na verdade assim, a violência da mulher, a gente não tem nada para encaminhar mesmo (ACS 4- GF1).

Então como você perguntou se tem uma direção. "Ah, a dona Maria apanhou e hoje ela não pode voltar pra casa dela, então nós vamos encaminhar né”. Igual, encaminha pro AMI, encaminha pro NIS, encaminha pro especialista [pausa], não tem. Daí aquele dia que a paciente da ACS 12 tava muito mal lá no posto, que saiu mais de cinco e meia da tarde esperando a ambulância, me veio lá a lembrança de quando eu tava no hospital com a minha mãe. Eu disse assim: "coitadinha, vai chegar lá, vai ser dopada, às vezes amarram né...” (ACS 15-GF3).

Daí depois volta pra casa e começa tudo de novo (ACS 11-GF3).

É que nem eu falo pra você, precisaria ter um local a onde destinar essa pessoa [pausa], porque mandar ela pro São Vicente [hospital], pro CAPS, pra unidade, ela vai voltar para a casa dela de novo né [pausa], precisa ter um serviço, assim como você vai no cardio, no uro, no pediatra, precisaria existir [um serviço específico para o atendimento de mulheres em situação de violência] (ACS 15-GF3).

[...] nessa parte de violência doméstica a gente [pausa] tem muito gás pra ajuda né, tem o CREAS, tem a "Casa Sol" [abrigo de mulheres] né, mas é coisa assim que, se chegar uma mulher aqui agora precisando de ajuda, a coisa precisa fluir na hora, tem que ser na hora. Não adianta pedir pra mulher voltar pra casa, ah daqui dois dias eu te ligo. Não, tem que ser na hora. Essas coisas tem que ser resolvido na hora, tanto quanto o cara alcoolizado, drogado que ele queria ser ajudado, tinha que ter sido resolvido na hora, você entendeu. Acho que essas coisas tem que ser resolvida assim, não adianta daqui a pouco ou daqui um dia. Daqui um dia ela tá morta né (ACS 13-GF3).

7 Texto extraído do site da Rede de Defesa de Direitos. [acesso em 20-05-2018]. Disponível em: http://www.redededefesadedireitos.com.br/orientacoes-basicas/confad-atendimento-para-conflitos-familiaresdificeis-centro-de-saude-escola-samuel-barnsley-pessoa-fmusp/ 
Embora não seja de conhecimento de todas as agentes comunitárias, o município de Jundiaí apresenta o abrigo de mulheres, conhecido como "Casa Sol”, e conta também com o apoio e suporte do CREAS às mulheres em situação de violência. As agentes apontam, no entanto, para a existência de um serviço capaz de garantir assistência a mulher em período integral, considerando suas necessidades emergenciais. Vale ressaltar que a Delegacia da Mulher, presente inclusive no município de Jundiaí, contempla os serviços de psicologia e de assistência social sendo também responsável por garantir a segurança da mulher, encaminhando esta e seus dependentes para o abrigo de mulheres, em caso de agressão ou ameaça.

Levando-se em consideração a resistência de muitas mulheres em procurar a Delegacia, é possível pensar na implantação tanto do Centro de Defesa e de Convivência da Mulher como também de uma Casa de Mulheres na localidade. Na capital de São Paulo, por exemplo, são 15 unidades do Centro de Defesa e de Convivência da Mulher (CDCM), com capacidade de atendimento para 1500 mulheres. Dentre os objetivos do CDCM destacam-se o fortalecimento pessoal e social das mulheres que porventura sofreram violência doméstica ou encontram-se em situação de vulnerabilidade, sendo contempladas pelos serviços de orientação psicológica, assistência social e encaminhamento jurídico (PREFEITURA DE SÃO PAULO, 2018).

No município de Curitiba, por sua vez, foi instituída a Casa da Mulher Brasileira de Curitiba, a qual procura garantir as condições necessárias para que a mulher enfrente a violência sofrida e resgate a sua autonomia. Este projeto é uma estratégia inovadora do governo e disponibiliza em período integral (24h) e no mesmo espaço, serviços de acolhimento e apoio psicossocial, a Delegacia da Mulher, a Defensoria Pública, o Juizado de Violência Doméstica e Familiar, o Ministério Público, a Patrulha Maria da Penha, programas voltados à autonomia econômica das mulheres e a brinquedoteca (PREFEITURA DE CURITIBA, 2018).

De acordo com a assessora de políticas para as mulheres do município de Jundiaí, após o lançamento dos "16 dias de ativismo para o fim da violência contra a mulher", uma campanha internacional ligada à ONU Mulheres, lançada em 27 de novembro de 2017 na cidade, surgiu a iniciativa para a criação de um grupo técnico com representantes dos serviços da rede de assistência, com o intuito de elaborar uma política específica do município às mulheres em situação de violência. Atualmente esse grupo tem se reunido mensalmente e está na fase de levantamento dos dados. Dentre as propostas encontra-se a elaboração de um Centro de Referência para as Mulheres. 
Vale ressaltar importante conquista do município com a Lei n. ${ }^{\circ} 8.800$, de 12 de junho de 2017, que institui a notificação compulsória de violência não apenas aos profissionais de saúde, mas a todos os estabelecimentos públicos ou privados de atendimento às pessoas, de ensino, de assistência social, de cuidado coletivo, de serviços de hemoterapia, unidades laboratoriais e instituições de pesquisa, nos termos da Portaria $n^{\circ} .1 .271$, de 06 de junho de 2014, do Ministério da Saúde (PREFEITURA DE JUNDIAÍ, 2018).

Embora a Lei municipal de notificação compulsória tenha entrado em vigor em 2017, a enfermeira da Vigilância Epidemiológica afirma que a lei não é de conhecimento de todos os profissionais. Menciona inclusive que não foi possível perceber, até o momento, um aumento no índice de notificações do município.

Segundo SALIBA et al. (2007), a notificação dos casos de violência, de obrigação ética e legal dos profissionais de saúde é negligenciada com frequência, o que dificulta o dimensionamento epidemiológico do problema e a implementação de políticas públicas direcionadas.

No relato a seguir, as agentes comunitárias apontam para a subnotificação dos casos de violência no município e a baixa resolutividade das ações, fatores que contribuem para agravar a invisibilidade desse fenômeno. Enfatizam também a demora no atendimento ao usuário e a capacitação do agente comunitário como alternativa para a não contratação de outros profissionais:

Mas em um município como Jundiaí, a assistente social da vigilância falou que a notificação existe desde 2011. Sabe quantas notificações teve o ano passado [2015]? Quatrocentas. Incluindo todo mundo, porque não é só mulher né. Tem mulher, negro, LGBT. Como pode isso? Como é que Jundiaí ganhou o prêmio de Cidade da Paz? E foi uma das coisas que falei para a gerente: "quer dizer que no nosso território não acontece nada né?" Não tem violência nenhuma, porque não tem notificação. Agora quatrocentos em Jundiaí, tá muito lento, aquém né. Um simples papel, um simples dado. No caso da mulher não aparece nada. A gente não consegue estatística, ela [assistente social da vigilância] tava fazendo na mão. A gente não consegue dizer quantas violências contra mulher ou contra qualquer outra pessoa teve no bairro entendeu, contra cada um pode ser notificado. $O$ sistema tá bem devagar, bem devagar, começando notificação, imagina as ações (ACS 3-GF1).

É que nem quando chega o pessoal aqui e faz barraco. Eu também faria, esperando três horas aqui uma consulta, imagina que você não vai fazer. É normal uma coisa dessa? Tem hora que eu não entro nem ali na frente, gente, porque eu entro e saio, entro e saio dá 11 horas e a pessoa tá esperando. Eu dou a volta pra não encontrar com o paciente (ACS 3-GF1).

Esse negócio de capacitação pra mim, apesar de no SUS existir, eu penso assim e já falei até em reunião: "tem capacitação pra médico? Tem capacitação pra dentista? Não. Por que tem capacitação de agente comunitário para dar aula de educação física? Capacitação de agente comunitário para atender nutrição? Capacitação dos agentes para fazer qualquer outra coisa que não seja médico e dentista?" É uma maneira de você não contratar. Capacitação para você aumentar 
seu conhecimento é uma coisa, concordo. Capacitação para você ficar no lugar de outro profissional é outra coisa (ACS 3-GF1).

As agentes relatam a subnotificação dos casos de violência, não apenas referente à violência contra a mulher, mas de modo geral. Observa-se que o registro anual de notificações é incoerente com a realidade do município. Os dados são alarmantes e refletem a desarticulação dos serviços, bem como a negligência da notificação entre os serviços de saúde e demais profissionais da rede de assistência. Logo, se o sistema de notificações não reflete a realidade do município, como serão elaboradas as ações? Assim, as agentes criticam a ineficiência desse sistema e também a desorganização dos serviços de saúde na prestação dos atendimentos.

Vale salientar que importante passo foi dado com a criação da Lei municipal n. ${ }^{\circ} 8.800$ que institui a notificação compulsória de violência aos demais profissionais da rede de assistência, além da articulação dos serviços para o desenvolvimento de uma política específica para mulheres em situação de violência. No entanto, seria interessante pensar em meios de divulgação dessa Lei entre os profissionais bem como as estratégias para torná-la efetiva.

Destaca-se também a crítica a não contratação e a desigualdade hierárquica entre os membros da equipe. As agentes discordam da capacitação do agente comunitário com o intuito de substituir, ou não contratar, o profissional qualificado para exercer determinada função, sendo o agente capacitado com a finalidade de executar o maior número de atividades possível.

Dentre as alterações sofridas no PSF, as agentes lamentam a diminuição das capacitações para enriquecimento do profissional, a falta de feedback das ações e a burocratização dos serviços:

Olha, vou ser bem sincera pra você, no início nós tínhamos muita capacitação, era muito bom. Produtiva. É [pausa], aumentava o estímulo na gente, a gente tinha assim [pausa], dava um choque na gente sabe, agora [pausa], agora parou, até isso parou. Agora é PA [crítica ao PSF que se transformou em um pronto atendimento]. É papel, você preenche, preenche e preenche e não leva à nada. Não temos um retorno e temos um tal de PMAQ [Programa Nacional de Melhoria do Acesso e da Qualidade de Atenção Básica], que tá pra vir novamente, fizemos uma correria, uma pasta desse tamanho, [...] e nem se quer conversaram conosco, com os agentes (ACS 12-GF3).

Nunca vi nem a nota, nem a verba que é pra gente receber [referia-se ao PMAQ]. Porque agora eles [governo] tem que registrar, tem que mostrar serviço, mostrar que está fazendo, mandar lá pro Ministério da Saúde para conseguir verba. [...] Está aparecendo cada vez mais programas aí, com mais um monte de papel que a 
gente tem que preencher e [pausa], a gente preenche os papéis, o programa acaba e a gente nem sabe por que preencheu os papéis (ACS 13-GF3).

Temos que cumprir a meta $x$ de visita, mais $y, z$ e $k$ tudo que tem direito. É quantidade, se trabalha com números (ACS 15-GF3).

É quantidade e [pausa] dinheiro. As meninas, as mais antigas, eu e a ACS 15 é da turma mais antiga. A gente se encontra e fala: "dona ACS 12, não é mais aquele PSF, não é mais aquele PSF ACS 15, não é mais aquele” (ACS 12- GF3).

Mudou pra pior [o PSF], a visão das pessoas quando eu entrei era uma coisa, era um pouquinho mais, ainda tinha gente que andava um pouco mais na rua pra buscar mais saber os problemas, hoje em dia tá parecendo um pronto atendimento. Tem paciente que vem e fala: "assina pra mim”. Eu vou e assino, já assinei várias vezes. Eles falam: “to bem, assina pra mim” (ACS 13-GF3).

Nota-se que a sobrecarga de trabalho das agentes comunitárias, decorrente de demandas internas e externas, bem como a cobrança excessiva por metas resultou em relações superficiais entre os usuários dos serviços e as agentes. Em seu discurso, as agentes lamentam as mudanças no PSF e criticam a burocratização dos serviços que resultaram na desumanização do cuidado. Nesta perspectiva, observa-se que a saúde e o cuidado com o usuário foram deixados para segundo plano.

Segundo BARRETO e HELOANI (2015), o capitalismo reestruturou os meios de produção, de agir e administrar o trabalho, visando maior produtividade e lucratividade. Essas novas formas de organização do trabalho desconsideram os laços afetivos e o espírito da coletividade, instituindo o mito dos colaboradores resilientes, da livre escolha, do empreendedorismo, da missão comum, da sustentabilidade e da ética corporativa.

O nível de estresse e o sentimento de revolta nas agentes são intensificados pelo acúmulo de atividades, recursos insuficientes e desvio de função, somados a relações verticalizadas de poder estabelecidas no ambiente de trabalho, precursoras de atos de violência:

[...] Às vezes o filho chegou e gritou com o seu João, ele tá triste, ele tá angustiado, ele quer te contar e você não pode. Aí você fica assim, aí você olha o celular: "meu Deus, olha a hora Senhor, eu tenho que ir pra unidade”. Você entendeu? Tem graça? Aí você chega na unidade vêm mil e uma informação, você tem que digitar isso, você tem que fazer isso, oh esse daqui você tem que preencher pra antes de ontem, aí tem mais esse daqui, esse... Que que é isso? Então daí eu fico assim sofrendo, dai eu falo: "Não Dona Maria, hoje não, porque eu não posso entrar". Minha cabeça tá lá na unidade, eu só pergunto: "tá tudo bem? Tá. Teve alguma intercorrência? Não ACS 15, tá tudo bem”. Isso é visita? Aí pra você chegar lá e passar no consolidado. Visitei $x$, y, z. Nossa bati a meta. Que meta que eu bati? Nenhuma. Pra mim não, pra mim é insatisfatório, insatisfatório. Isso desgasta o agente comunitário e tem muito agente comunitário com depressão, afastado, você entendeu? (ACS 15-GF3).

Nós temos uma amiga que foi transferida pra [pausa] Agapeama, porque ela mudou lá pro bairro da Agapeama. O pagamento é o mesmo, nós estamos defasadas, não 
poderia já pegar uma das meninas que passaram no concurso? Já por pra cobrir essa área? Não. Usa nós (ACS 12-GF3).

Aí vai ter que preencher os papéis da nossa área que já é muito, vai ter que preencher os papéis da outra área... Serviços que não é nosso eles mandam pra gente fazer. [...] a gente sabe que tá digitando muita coisa, e não tá escrito nada [no livro de agentes comunitários] que nós temos que digitar nas nossas atribuições. Isso é uma violência que fazem contra as mulheres, que a maioria das agentes é mulher. É violência contra a mulher no trabalho. Muitas vezes a chefe acaba violentando várias outras pessoas na unidade, que a maioria é mulher, porque quer que seja cumprida as metas, não respeita opiniões, não respeita as [pausa], às vezes os problemas que acontece não respeita. E às vezes acaba tendo violência no trabalho contra a mulher (ACS 13-GF3).

As agentes comunitárias revelam as angústias advindas do conflito entre a qualidade do atendimento e a quantidade de atendimentos prestados. Apontam para o desgaste do agente comunitário pela sobrecarga de atividades em função das metas, assim como pelas demandas excedentes em virtude da defasagem do quadro de agentes comunitários, evidente em todas as unidades de PSF do município.

De acordo com BARRETO e HELOANI (2015), apresentar bom desempenho ou ser leal às normas e princípios éticos não é mais garantia para permanência no emprego. $\mathrm{O}$ enfoque é quantitativo, logo importa ultrapassar a meta e dar produtividade. Assim, essa nova ordem de trabalho, regida pelo capital, não permite, nem tolera os improdutivos, independente das causas.

Para as agentes, as demandas excedentes são identificadas como uma forma de violência contra a mulher. Além disso, avaliam a postura da gerência de reivindicação às metas como violenta, configurando uma espécie de violência institucional. Segundo BARRETO e HELOANI (2015), a violência laboral tem raiz profunda na organização do trabalho. $\mathrm{O}$ abuso de poder e o assédio moral, presentes muitas vezes na forma de gerenciar, podem ser responsáveis pela produção de tensões, focos de instabilidade, relações de isolamento, de violência e intolerância.

Nota-se no discurso das agentes, o sentimento de desvalorização ao serem tratadas como "tapa buraco", sem o devido reajuste salarial ou contratação de outro profissional para o preenchimento do quadro de funcionários. No relato abaixo, as agentes mencionam a defasagem salarial, o repasse insignificante de verba e o baixo investimento no profissional como aspectos desmotivadores:

Quando a gente entrou [no PSF], em Assis, era duas, três vezes mais que aqui, a nossa colega foi lá e quando voltou e disse: "Gente nós não tamo ganhando nada, o 
pessoal de lá ganha duas, três vezes mais do que nós" e é agente de saúde a mesma coisa. Depois que foi igualando, igualando, igualando (ACS 12-GF3).

Vou pro Nordeste, receber uns três pau no Nordeste, porque aqui não vale nada o nosso salário (ACS 13-GF3).

Eles têm que repor pra gente [material], mas eles não repõem o tanto que têm que repor. Porque como que foi a história do material, o colega aí que sabe mais, que nós fomos no advogado uma vez i.... (ACS 12-GF3).

[...] tinha mais de 500.000 reais para utilizar com a gente. Não sei onde eles [município] colocaram esse dinheiro que não usaram [pausa], e até hoje não responderam. Deram material pra comprar essas camisetas, dez reais, cinquenta reais essa camisa. A sacola que arrebenta. Mandou fazer de segunda. Minha prancheta nem uso, uso uma que eu tenho. Não dão tênis, não dão roupa, não dão nada. Aí querem meta (ACS 13-GF3).

As agentes retratam em suas falas como se sentem exigidas e cobradas nos serviços de saúde e ao mesmo tempo pouco valorizadas, seja pela defasagem salarial, pela falta de feedback das ações ou ainda pelo baixo investimento no profissional, ao fornecerem material de segunda linha e insuficiente as necessidades de trabalho.

Além das exigências, cobranças e sobrecarga de atividades as quais estão submetidas, as agentes estão sujeitas a possibilidade real de violência em sua rotina de trabalho. Assim, os casos de agentes assassinados divulgados pela mídia reforçam a insegurança e o medo das agentes durante as visitas domiciliares:

[...] até os agentes comunitários agora tá sofrendo risco com uma [pausa] violência. Por quê? Eles tão divulgando tanto a morte de agente comunitário que agora virou moda. Têm vários lugares: Minas, São Paulo, Bahia. É, mas tá acontecendo muito né, então pra gente que trabalha na área, é que a gente conhece todo mundo aqui, mas você vê alguém novo, a gente já vai esperto fazer a visita (ACS 11- GF3).

Não, até os que já são velhos [usuários do serviço] (ACS 15-GF3).

A gente não sabe o que vai encontrar lá (ACS 14-GF3).

Eu mesmo não entro em casa de nenhum homem que eu sei que tá sozinho em casa. Eu converso ali no portão mesmo, entendeu... Nossa colega de trabalho mesmo [exagente comunitária], quantas vezes eu não via ela na rua e os caras mexia. Os caras mexia, falava gostosa, aí eu chegava até a ficar brava. Homem casado, que mora aqui e conhece o marido dela. Assédio. É uma violência né. E sofre. Quantas meninas bonitas aí não acontecem isso (ACS 11-GF3).

Segundo BAUMAN (2008), os medos do indivíduo podem ser de três tipos. Alguns ameaçam o corpo e as propriedades. Outros ameaçam a durabilidade da ordem social e a confiabilidade nela, da qual depende a segurança do sustento. E por último, os perigos que ameaçam o lugar da pessoa no mundo, referente à posição na hierarquia social, a identidade e a imunidade à degradação e à exclusão social. 
BAUMAN (2008) declara o medo comum dos animais e seres humanos no tocante as reações de fuga ou agressão ao enfrentar uma ameaça. Destaca, no entanto, um medo específico aos seres humanos, de ordem social e culturalmente "reciclável”, o qual denominou como "medo derivado". O autor explica a expressão referindo-se ao sentimento de ser mais suscetível ao perigo, uma sensação de insegurança e vulnerabilidade. Assim, para uma pessoa que tenha interiorizado tais representações e utilize essas lentes para enxergar o mundo, mesmo na ausência de ameaça real, as reações ao "medo derivado" apresentarão os mesmos efeitos.

As agentes revelam o medo de ameaça à própria vida, mas também o medo do desconhecido: “A gente não sabe o que vai encontrar lá. Eu mesmo não entro na casa de nenhum homem que eu sei que tá sozinho em casa". Neste aspecto, BAUMAN $(2008$, p.8) afirma:

O medo é mais assustador quando disperso, indistinto, desvinculado, desancorado, flutuante, sem endereço nem motivos claros; quando nos assombra sem que haja uma explicação visível, quando a ameaça que devemos temer pode ser vislumbrada em toda a parte, mas em lugar algum se pode vê-la. "Medo" é o nome que damos a nossa incerteza: nossa ignorância da ameaça e do que deve ser feito - do que pode e do que não pode- para fazê-la parar ou enfrentá-la, se cessá-la estiver além do nosso alcance.

A falta de atenção às demandas das agentes, suporte e respaldo, reflete em danos a saúde e desânimo na rotina de trabalho. Observam inclusive que a equipe está adoecendo e necessita de apoio e ajuda:

Fizemos um [Fórum de ACS] agora, não teve retorno. Acaba em pizza (ACS 12 GF3).

Você fala lá e ali naquela hora é aquela festa, é aquelas promessas, a gente vai ajudar, a gente vai melhorar e depois nada faz (ACS 11-GF3).

[...] Tem agente afastado já de depressão, porque tem gente que num aguenta [pausa] u suporte. Aqui por enquanto ainda nós estamos aguentando né, mas... A gente sempre pediu que precisava da psicóloga pra principalmente com os agentes, que ela trabalhasse junto com a equipe, que uma ou duas vezes na semana ia em cada equipe, daí você no caso você tá fazendo a pesquisa, mas digamos que você fosse uma psicóloga contratada da prefeitura pra gente, pra dar assistência pra gente, vinha um, marcava um dia a tarde você vinha com a gente, depois vocês iam pra outra unidade, mas não temos esse apoio (ACS 12-GF3).

Uma equipe desmotivada é triste pra trabalhar. A nossa equipe tá doente. A nossa equipe está doente (ACS 12-GF3).

As agentes demonstram a frustração e o desapontamento com os órgãos responsáveis pela administração e gestão das unidades de saúde da família. Revelam a necessidade de 
supervisão e acompanhamento dos casos, que muitas vezes demandam, além de conhecimentos específicos, uma abordagem de trabalho direcionada. Apontam que a negligência do cuidado e assistência ao cuidador reflete em agravos a saúde, tendo como consequência a diminuição do quadro de profissionais e o adoecimento da equipe. Outros fatores como a gestão inadequada ou a ausência dela, assim como a infraestrutura questionável das unidades, contribuem para o adoecimento dos profissionais de saúde:

[...] Depois do último ano pra cá eu ando com a minha imunidade baixa mesmo e é por conta de um monte de coisa que aconteceu. Nós saímos daqui, fomos jogados ali, tiraram a chefia nossa... O paciente em si lá é bem o que a gente tava conversando. Se eu tiver numa casa e me estressar, acontecer alguma coisa, eu vou na outra. Dali a não ser que nós tivermos que entregar alguma coisa, a gente só vai ver dali a 1 mês, entendeu. Agora ali [unidade], o que está acontecendo, falta de espaço nosso, tudo essas coisas e fora isso daí de não ter respaldo das coisas que a gente fala (ACS 21-GF4).

De acordo com BARRETO e HELOANI (2015, p. 554), “um trabalhador sadio é aquele que apresenta um bom equilíbrio entre corpo e mente; está em harmonia com seu entorno físico e social; controla plenamente suas faculdades físicas e mentais sem dicotomias". O processo de adoecimento no trabalho, entretanto, pode estar associado a causas multifatoriais. Alguns elementos como a relação do trabalhador com o meio ambiente, as condições de trabalho e as relações laborais podem abalar o bem-estar do indivíduo com prejuízos a sua saúde física e mental. A cobrança por desempenho, com ritmo e metas abusivas; a exigência de tarefas excessivas e muitas vezes sem sentido; o estilo de liderança impositivo, marcado pela ausência do diálogo, respeito, reconhecimento e desconfiança são apenas alguns dos fatores que contribuem para a construção de tensões no ambiente de trabalho (BARRETO E HELOANI, 2015).

Observa-se que os profissionais de saúde, dentre eles as agentes, têm demandado um cuidado especial. Inclusive, a burocratização dos serviços tem favorecido o desenvolvimento da baixa imunidade e depressão nas agentes comunitárias. Acredita-se que a ausência de gestão e infraestrutura própria, considerando que esta UBSF compartilha o mesmo espaço físico da UBS tradicional do bairro, esteja desfavorecendo a integração entre os membros da equipe:

[...] Não dá pra confiar 100\% [no ser humano]. Só em Deus. Eu não confio 100\% nem em mim, porque eu já mudei muitas vezes de opinião, então tem coisas que eu acho que é ética. Mas naquele dia brigaram comigo porque eu não dei nome, entre aspas deram uma dura em mim, porque eu não tava confiando nos profissionais. 
Não dá pra confiar. Soltou isso lá na rua, que a pessoa traiu o marido, que eu falei em reunião, vixe Maria, eu não trabalho mais. Tem coisas que é muito sigilosa, não dá pra gente contar. Já aconteceu comigo de eu ficar mal vista, por uma coisa que eu nem fiz. Eu trabalho em uma submoradia, foram falar lá que eu chamei o pessoal todos de favelado. Ah meu Deus, deu um rebu de duas semanas isso aí. A minha sorte é que a boca de quem chegou eu tinha acabado de fala, e era uma pessoa que tinha chegado a pouco tempo na comunidade, contra mim que tô há 7 anos, então muitas pessoas falaram assim: "a gente sabe que você não faria isso, porque há 7 anos você já teria pisado na bola com a gente”. Então foi pura maldade da pessoa, pra me ver prejudicada, pura maldade e é da equipe gente (ACS 17- GF4).

Não dá pra gente contar esse tipo de coisa em reunião de equipe, porque o PSF aqui tem muita gente, muitos funcionários, então não tem como falar [pausa] $e$ vaza, corre risco de vazamento (ACS 16-GF4).

A gente já falou na outra reunião que a gente gostava da conduta do Dr. Gilberto e Dr. Juliano, que era quem tem que saber e que já tava na área e sabe da situação e os próprios agentes. Ficar expondo pra equipe não tem propósito, porque quem vai tá ali ajudando a segurar a bucha, resolvendo é quem tá na área né e não os outros agentes (ACS 21-GF4).

Chama a atenção nesta unidade, a desconfiança das agentes nos demais profissionais da equipe. É bem verdade, que o sigilo e a ética nos serviços de saúde nem sempre são mantidos, porém, as reuniões de equipe e matriciamento têm como finalidade garantir o suporte e o apoio aos profissionais de saúde, por meio da discussão e direcionamento dos casos. Vale ressaltar que a ausência da gestão e infraestrutura própria dificulta o planejamento das ações e contribui para a fragmentação da equipe. Neste sentido, a pesquisadora aponta que as reuniões de equipe e matriciamento tanto da UBSF como da UBS tradicional eram realizadas em conjunto. Sendo assim, a interação entre os profissionais era desfavorecida em virtude do alto número de participantes, bem como o estabelecimento de laços de confiança.

\subsubsection{Práticas dos Agentes Comunitários de Saúde a Mulheres em Situação de Violência}

Em sua rotina de trabalho, as agentes valorizam a singularidade do usuário ao realizarem determinada orientação. Assim, destacam a inexistência de um perfil ou padrão de orientação, valendo-se de práticas diversificadas às mulheres em situação de violência:

É no momento [a orientação]. Não dá pra eu falar pra você no ambiente bom que a gente tá, o que falar, você teria que passar o problema, pra eu responder na hora. De repente eu vou dar uma orientação pra você que é da igreja católica, vou dar pra ela que é da Assembléia de Deus de outro jeito, em outras palavras, outros caminhos. A gente pode aconselhar, promover, orientar, mostrar certos caminhos, mas ele escolhe, é livre arbítrio, né? Cada pessoa é uma pessoa, você pode ter um 
velho ou uma velha, um adolescente ou uma criança. E daí? Você tem um jeito diferente de falar com cada um. Não tem como falar assim de momento como seria o tratamento. [...] Na rua dia a dia a rotina é dinâmica. Nada é igual a outro dia, é tudo diferente. Não há pessoas iguais, então não tem como orientar igual (ACS 17GF4).

Embora o cuidado ao usuário deva ser contextualizado às questões sociais, culturais, questões de gênero e raça para que medidas e ações sejam pensadas algumas similaridades no processo de orientação são verificadas entre as agentes, como a escuta e o diálogo com o usuário bem como a discussão dos casos com a gerência ou com a equipe:

Pra mim como agente, eu acho que você deve ouvir o paciente, dependendo da situação passar para a equipe né, e assim [pausa] não dá para você falar faz isso ou faz aquilo (ACS 4- GF1).

Normalmente é assim, desconfiou, a gente chega pra enfermeira, olha tem alguma coisa ali, tava com mancha roxa, mas a pessoa não me dá liberdade, a pessoa é fechada, responde lá do portão: "ah, eu não tô". Responde lá da porta e você lá no portão. Então assim, é casos e casos. Diferente de uma que: "Oi, tudo bem, entra, vamos conversar". Sempre te recebeu bem, te recebe bem, conta alguma intimidade. Então assim, cada caso é um caso (ACS 20-GF4).

As agentes enfatizam que a confiança e abertura do usuário e seus familiares ao profissional estão diretamente relacionadas à abordagem utilizada e a vinculação estabelecida, que faz parte, por sua vez, de um processo lento e gradual:

Então assim, a questão de confiança demora anos. No caso da ACS 3, a paciente veio relatar [situação de violência] depois de sete anos. [...] eu estou aqui a sete anos, eu consegui entrar no quarto da dona Geralda [paciente idosa, com transtorno mental] esses dias atrás, ver a realidade do quarto dela. Então assim, é um trabalho de formiguinha (ACS 1-GF1).

Mas daí a família como tem vínculo com a gente, procura né. Procura vir desabafar, conversar, vem pedir ajuda (ACS 15-GF3).

Neste relato, as agentes apontam para a importância das tecnologias leves ao cuidado em saúde, que segundo MERHY (2009), valoriza o encontro entre trabalhador-usuário mediante a escuta, o interesse, a construção de vínculos e a confiança. É interessante pensar no trabalho de formiguinha mencionado pelas as agentes, pois, se você não enxerga o horizonte, como você irá desenhá-lo? Se o processo de mudança não pode ser visualizado pelo profissional e este não acredita que a sua intervenção poderá beneficiar o usuário ou contribuir para a melhoria do atendimento, qual seria o propósito e significado dessas ações? 
Segundo o médico da USF Vila Esperança, a abordagem a ser utilizada em situações de violência é fundamental. Questiona, entretanto, como intervir sem quebrar o vínculo com o usuário e sem se tornar vigilante da ética. Aponta, neste sentido, para a deficiência nos currículos de formação ou mesmo a ausência de capacitações ou treinamentos na UBSF envolvendo a temática.

Essa ausência de capacitação e treinamento nas unidades de saúde reflete, por sua vez, nas práticas dos profissionais. As agentes comunitárias, por exemplo, consideram e defendem que a intervenção do profissional deve ocorrer apenas mediante o pedido de ajuda da mulher. Novamente a questão da autonomia feminina e o respeito à esfera privada e particular das relações aparecem no discurso das agentes:

\begin{abstract}
Se a pessoa não quer ajuda, você não faz nada, mas se você aconselha e a pessoa busca sua ajuda, aí você procura resolver o problema. Mas se a pessoa não quer a sua ajuda [pausa], você dá os conselhos e a pessoa não quer, você vai fazer o que com isso? Às vezes, como aconteceu na minha área, é [pausa], o pai bateu no filho né, chega aqui e fala: "caiu na escada, tropecei", muitas vezes ele esconde isso, mesmo você tendo vínculo, ele fica omitindo. Muitas vezes não fala porque não quer prejudicar o pai, o marido, aí começa a omitir os fatos. Como acontece muito, tem até propaganda na TV que fala: "Cai da escada, tropecei no tapete" (ACS 13GF3).

E outra, a pessoa tem que pedir ajuda. Olha, eu respeito muito o livre arbitrio, eu não sou Deus pra querer rancar a verdade de ninguém... E sem a pessoa querer é invasão de privacidade. Que nem hoje eu encontrei uma pessoa com olho roxo e sou bem safada, eu entro com tudo pra descobrir sabe, pra tentar dar uma luz, porque graças a Deus experiência a gente tem um pouquinho. Nunca apanhei, mas fui casada com um cara drogado. E ai eu perguntei: "que é isso nos seus olhos?" Ela levou uma cassetada, bebeu e caiu. Teve a ajuda do álcool, porque eu sei que ela bebe um pouquinho. Ai ela falou assim: "eu cai. Também você quer o que, eu tenho 82 anos". Mas nem parece. Rancou os tapetes? Daí a gente entra com orientação. Então cada caso é um caso. Mas se ela levou um tapa de um filho ou de alguém, eu nunca vou saber. Eu vou orientar ela a fazer o que? Bola de cristal? (ACS 17GF4).
\end{abstract}

É importante considerar as razões da mulher para omissão dos fatos. Se existe o vínculo com o profissional e mesmo assim a mulher não fala a respeito da realidade de violência, algumas possibilidades podem ser cogitadas. O medo de prejudicar o parceiro, a exposição do relacionamento, a ligação afetiva ou mesmo o medo de retaliação. $\mathrm{O}$ fato da mulher não buscar ou procurar ajuda, não significa que esta não precise de apoio profissional. Nesta perspectiva, algumas questões podem ser levantadas: será que a mulher encontra-se em condições de procurar ajuda? Em caso de reconhecimento da demanda de violência como um problema inerente à saúde, estaria o profissional habilitado para realizar e garantir o suporte necessário a essa mulher? E por último, até que ponto as agentes comunitárias se sentem 
seguras e estão protegidas dentro de uma estrutura que envolve a saúde, a seguridade social e a polícia?

Dentre os serviços ofertados pela rede de assistência, as agentes preferencialmente encaminham as mulheres para as UBSF, muito embora reconheçam a existência de outros serviços, como o CREAS, o abrigo de mulheres, a delegacia da mulher, o CAPS, o hospital São Vicente, ou mesmo o serviço de psicologia oferecido por algumas faculdades:

A chamada principal que às vezes eu acho, é retirar essa mulher de dentro de casa, porque muitos ficam dentro de casa muito tempo. Se a gente conseguir trazer ela pra unidade para fazer qualquer coisa, já tem chance de conversar com mais alguém e sair um pouco (ACS 3-GF1).

A gente tem o grupo do NASF [grupo de psicologia] que tá ajudando bastante a gente aqui [na unidade]. Esse grupo é bom, porque [pausa] eles conseguem levantar a autoestima [da mulher] e pontuar situações que ela vê que às vezes ela pensa que a situação dela é a pior, mas não, tem gente que vive uma situação [pausa] pior e consegue dar a volta por cima. Só falta uma coisa: ela decidir (ACS 7- GF2).

As agentes levantam um aspecto importante para a abordagem inicial às mulheres em situação de violência. Independente dos serviços disponíveis, as agentes entendem que a mulher deve ser retirada do contexto de violência. Em virtude da condição de fragilidade, muitas vezes essa mulher não enxerga outros caminhos e possibilidades. Assim, cabe ao profissional da rede de assistência acolher, apoiar, apontar caminhos e possibilidades. Neste sentido, as agentes comunitárias em visita domiciliar podem reforçar os serviços disponíveis em rede e o convite para a participação nos grupos do NASF ou em outras atividades ofertadas pela unidade de saúde.

Vale ressaltar que a sensibilidade do profissional para além das demandas manifestadas pelo usuário é essencial, pois, o processo de orientação precisa ir ao encontro das necessidades individuais. Afinal, o cuidado em saúde não envolve apenas aquilo que o usuário solicita, mas também, aquilo que a experiência, sensibilidade e intuição do profissional revelam. É verdade, não existe bola de cristal, porém o interesse pelas demandas e bem-estar do indivíduo faz toda a diferença em termos de ações.

Dentre as orientações dos profissionais da equipe de saúde às mulheres em situação de violência, alguns serviços da rede de assistência são mencionados, como a Delegacia, o Ambulatório de Saúde da Mulher e o CTA (Centro de Testagem e Aconselhamento) para casos de violência sexual. Havendo a necessidade de abrigo para mulheres e crianças, apontase a "Casa Sol". Nas unidades de saúde da família, o grupo de psicologia do NASF é 
destacado como importante auxílio ao usuário em sofrimento psíquico. Outros serviços como o ambulatório de moléstias infecciosas, a promotoria, a Coordenadoria da Mulher, o CREAS e o CRAS também são apontados.

Observa-se entre as agentes comunitárias a inexistência de um consenso quanto à orientação da denúncia e do boletim de ocorrência. O medo de retaliação ou perda do vínculo com o usuário ainda são predominantes, refletindo-se nas práticas das agentes:

\begin{abstract}
Porque daí a gente faz a visita, muitas contam pra gente dos fatos. A gente sabe muita coisa que a gente nem deveria saber. Têm muitas que a gente orienta: "procura a delegacia". Aí em uma briga sei lá, solta que foi a gente. A gente mora aqui no bairro, dai esse marido com certeza vai cair em cima da gente. Dependendo de quem, eu não oriento. Dependendo do paciente eu não oriento, eu não falo nada. A gente fica neutra, neutra mais do que sabão de bolinha, não expressa opinião. Quando elas vêm se queixar de alguma coisa pra gente, a gente tenta ir pra outros meios a não ser denunciar, porque elas mesmas podem falar que a gente orientou. A gente encaminha pra esses grupos, consultas, conversas. Então é assim, a gente parte pra outros jeitos (ACS 7- GF2).

Meu receio é da pessoa não me receber mais em casa, mas tem o termo de recusa que você pode levar lá, pra pessoa não me receber mais. Você pode perder o vínculo [pausa] ou não, mas eu não tenho problema se eu tiver que denunciar (ACS 13- GF3).

A gente perde o paciente [ao fazer a denúncia] e ao mesmo tempo a gente invade a privacidade dele, porque ela não vai mais querer saber, passar algo pra você e até mesmo o que que eles podem tá fazendo com a gente. Então é algo muito difícil pra já entrar de cabeça num assunto desse daí. Até mesmo quando as meninas falam: "eu vou em reunião isso e aquilo", é complicado a gente se expor. Eu acho que não é algo que a gente deve ficar muito a par dessas coisas (ACS 23-GF5).
\end{abstract}

O medo da exposição e retaliação reflete na neutralidade de muitas agentes, que preferem não orientar a realização da denúncia pelo contexto de vulnerabilidade ao qual estão expostas. O receio em perder o vínculo, arduamente conquistado, e invadir a privacidade do usuário contribui para a orientação de outros caminhos e possibilidades, que não envolvam a denúncia policial. Chama a atenção, porém, o discurso das agentes: “[...] A gente sabe muita coisa que a gente nem deveria saber. [...] Eu acho que não é algo que a gente deve ficar muito a par dessas coisas" (ACS 7-GF2). Nota-se o temor das agentes em se comprometerem com os casos de violência. No entanto, se a violência não é algo que o profissional de saúde deve ficar “a par”, como serão pensadas as ações? Desse modo, a violência contra a mulher permanece velada nos lares pela questão da privacidade.

Uma parte minoritária das agentes, contudo, defende a orientação da denúncia e realização do boletim de ocorrência: 
Ah eu se tiver que orientar, ou mandar pra delegacia, eu já oriento [pausa], eu não tenho medo. Eu acho assim, você não pode ter medo, você não pode abaixar a cabeça, porque daí é pior. Eu se precisar chamar, eu também chamo (ACS 6- GF2). Eu tenho uma postura assim: "se vira, faz a denúncia e separa. Chuta o balde e vai vender doce”. Eu tenho uma postura bem assim, eu mando mesmo, vai pra delegacia da mulher, não, vai (ACS 3-GF1).

É interessante pontuar que as agentes que se manifestaram a favor da realização da denúncia eram mulheres mais velhas, com espírito de liderança e tempo de trabalho na unidade. Considera-se que as vivências pessoais e maturidade das agentes, somadas à experiência de trabalho, bem como aos aspectos inerentes a sua personalidade, tenham contribuído para a postura assumida no que diz respeito às mulheres em situação de violência. Nesta perspectiva, valoriza-se a autonomia e capacidade da mulher para romper o relacionamento abusivo e assumir sua independência. Entretanto, deve-se cuidar para não incorrer na armadilha de responsabilizar a mulher pela violência sofrida.

De acordo com as agentes comunitárias, as queixas de violência contra a mulher normalmente são casos de encaminhamento do CREAS e do abrigo de mulheres. Ou ainda, dos serviços de saúde, em consulta com o médico ou em contato com a gerência. Nos casos de encaminhamento pelo CREAS ou pelo abrigo de mulheres, as agentes acompanham as famílias em questão e contribuem para a discussão dos casos em reunião de equipe:

A gente fica mais ou menos sabendo [casos de violência contra a mulher], quando vem pra gente em caso social, tipo assim, que foi parar na delegacia, a gente não ficou sabendo, daí foi pro CREAS ou chegou no abrigo e aí vem pra gente fazer a visita, pra gente ver o que está acontecendo, daí a gente participa de algumas reuniões (ACS 24- GF5).

Verifica-se que os casos de violência se tornam de conhecimento das agentes por meio dos encaminhamentos do CREAS e do abrigo de mulheres. Mesmo nos serviços de saúde, esses casos são trazidos pela gerência ou pelo médico. Sendo assim, as agentes assumem uma postura passiva diante do contexto de violência, restringindo sua participação à solicitação de terceiros.

De acordo com a assessora de políticas para as mulheres, o município trabalha com o protocolo de violência do Ministério da Saúde. Aponta, inclusive, para a existência de um projeto que visa à criação de um protocolo específico para os casos de violência do município.

Pelas observações da pesquisadora em campo verificou-se, entretanto, o desconhecimento das agentes quanto à existência de um protocolo para casos de violência. 
Vale questionar se este protocolo é de desconhecimento dos demais profissionais da equipe, assim como as razões para não ter sido adotado como uma exigência de trabalho. Neste sentido, mais importante do que a criação de um protocolo específico para casos de violência do município, seria pensar nas estratégias para torná-lo uma realidade nas práticas dos profissionais.

Nesta perspectiva, observa-se um limite nas práticas das agentes comunitárias a mulheres em situação de violência. O excesso de atividades, a falta de qualificação para atender determinadas demandas ou a compreensão de que a demanda de violência compete a outro profissional, exemplificam algumas dessas limitações:

\begin{abstract}
Às vezes você quer ajudar ela [mulheres violentadas] só que [pausa] você tem tantos outros problemas que você tem que resolver, trabalhar durante o dia [pausa] que não tem, por exemplo, no hospital às vezes é muito difícil de você dar esse cuidado pras pessoas. Numa unidade básica do bairro UBS, às vezes, você consiga como OSF. Mas se você chega num pronto atendimento lá tem uns guardas que protegem, aí chega no hospital falando sobre isso às vezes é difícil, se você não chega tão ferido, eles cuidam e mandam você pra casa (ACS 13-GF3).

Você não aguenta, não aguenta, é muita, muita pressão. Eu já dou assistência a ela [idosa de 92 anos, depressiva, ameaça de suicídio], passo lá uma vez ao mês, passo até um pouco mais. "Não, mas dai você dá uma pouco mais" [cobrança de outros profissionais à agente comunitária]. Você quer o que? que eu passe três vezes por semana? Daí eu não vou aguentar, sou eи que vou me internar e não dá tempo da gente passar né. Tem outros também para você cuidar. Ela tá querendo que você faça o papel dela, quem tem que dar esse acompanhamento porque daí eu escuto, mas eu não tenho devolutiva porque eu não sou psicóloga. Mas como é que eu faço escuta? Mas como é que eu vou ficar fazendo escuta toda vida, o que é que eu falo? Eu não sei, eu não sou psicóloga. Eu não trabalho (ACS 3-GF1).

Têm coisas que você não pode ficar abraçando, porque você já não dá conta do que você tem pra fazer. Então chega um certo ponto que você se isenta. Você percebe é uma assistente social que vai ter que resolver isso, não é o agente de saúde (ACS 17-GF4).
\end{abstract}

As agentes apontam que a sobrecarga de atividades, cobrança e pressão na rotina de trabalho impedem ou dificultam, muitas vezes, a assistência a mulheres violentadas. Existe o desejo em ajudar, mas outros problemas e atividades paralelas surgem e concorrem entre si. $\mathrm{O}$ tempo se impõe como limite e não há como oferecer maior suporte a um usuário e desassistir a outro. As agentes retratam como são exigidas em sua rotina de trabalho. Muitas vezes, inclusive, são cobradas em assumir funções para as quais não se sentem preparadas, ou entendem como sendo da competência de outro profissional. Neste sentido, entretanto, se a violência não é vista como questão de saúde, logo, as ações se tornam obsoletas. 


\section{CONSIDERAÇÕES FINAIS}

O contato com as agentes comunitárias em reuniões de equipe, matriciamento, reuniões de ACS, visita domiciliar e outras atividades propostas pelas UBSF do município de Jundiaí, bem como a discussão da temática em grupo, possibilitaram a pesquisadora observar a estreita relação entre as representações das agentes e suas práticas adotadas durante a rotina de trabalho.

Chama a atenção o questionamento da agente à pesquisadora no decorrer da discussão em grupo: "Daí você tá falando pra gente falar nossa opinião pessoal, não como profissional né? Porque como profissional a gente tem que ter outra postura. Não pode expressar a opinião" (ACS 7- GF2). "Tem que ser neutro" (ACS 6- GF2). Essa fragmentação entre as representações pessoais e as práticas das agentes como profissionais poderiam ser repensadas e problematizadas. Afinal, seria possível às agentes estabelecerem um perfil profissional desvinculado de suas representações pessoais e que não influenciasse suas práticas?

De algum modo as agentes estão trazendo que existe uma expectativa dos serviços e dos profissionais de saúde quanto às práticas dos agentes comunitários, o que, nem sempre corresponde às suas vivências pessoais e compreensão dos fenômenos. Essa neutralidade, entretanto, referida pelas agentes é apenas ilusória, pois, a todo o momento observou-se suas práticas sendo sustentadas pelas referências pessoais e pelos estereótipos de gênero.

Dentre as representações das agentes, evidencia-se a responsabilização da mulher pela violência sofrida e o discurso de autonomia para romper com o ciclo de violência, assim como a compreensão da vida íntima do casal como sendo de âmbito privado. Em virtude de alguns mitos como "em briga de marido e mulher, ninguém mete a colher", tanto as agentes comunitárias como os demais profissionais da equipe assumem uma postura de passividade, conivência e omissão que reforçam a invisibilidade do problema. Dessa forma, justifica-se a baixa demanda dos casos de violência nos serviços de saúde, que geralmente ocorrem por meio de encaminhamento.

Vale ressaltar que, se a mulher é considerada culpada pela agressão ou autossuficiente para sair do relacionamento abusivo, bem como se a violência é entendida como um aspecto privado inerente ao relacionamento do casal, consequentemente, os serviços de saúde perdem seu potencial de ação. 
Observa-se o descrédito das agentes na Lei Maria da Penha e na efetividade da denúncia, além da recorrente confusão entre notificação compulsória e denúncia policial. Essas representações somadas ao medo de exposição e retaliação refletem em seu processo de orientação às mulheres em situação de violência ao apontarem outros caminhos que não envolvam a denúncia policial.

Entretanto, vale ressaltar que não apenas as agentes comunitárias, mas também os demais profissionais da equipe são enredados pelo medo. Por se tratar de um território de tráfico, as representações quanto ao uso de substâncias psicoativas e sua relação com a criminalidade são frequentes. Neste cenário, os profissionais de saúde, em especial as agentes comunitárias, encontram-se em situação de vulnerabilidade. Por esta razão, os serviços de saúde acabam aceitando as "leis de convivência" da comunidade e fazem "vista grossa" ao se depararem com o problema.

Desse modo, a ausência da adesão do protocolo de violência pelas UBSF para nortear as ações dos profissionais de saúde, bem como da iniciativa da gerência em torná-lo uma exigência de trabalho, reforça as representações das agentes quanto à concepção da violência como um problema exclusivamente social. Sendo assim, a atuação dos profissionais de saúde é reduzida aos efeitos da violência, mas não a tratar os aspectos da prevenção. Neste sentido, a inclusão do protocolo de violência no contrato de gestão poderia contribuir para o alcance da política no município.

Outro ponto importante a considerar se refere à dificuldade dos profissionais com relação às abordagens da violência, o que remete à defasagem nos currículos de formação, à ausência de capacitação e supervisão dos casos, contribuindo para a perpetuação da "lei do silêncio". Logo, a dificuldade em lidar com os casos de violência não é apenas das agentes, mas de todos os profissionais da equipe, que carecem de uma capacitação continuada, como se propõe a fazer a Política Nacional de Educação Permanente, a qual integra o "Plano Municipal de Saúde 2018-2021” de Jundiaí.

Por fazerem parte da comunidade, as agentes se encontram em um contexto de maior vulnerabilidade e exposição à violência. Inclusive, muitas delas já vivenciaram ou vivenciam trajetórias de violência. Dessa forma, a saúde apenas será um apoio e suporte às mulheres em situação de violência, quando este fenômeno for compreendido como um problema de âmbito da saúde. Sendo de âmbito da saúde, qual a condição efetiva dessas profissionais em garantir esse suporte à mulher? E ainda, o quanto as agentes se sentem preparadas e seguras dentro de uma estrutura que envolve a saúde, a seguridade social e a polícia? 
Observa-se a dificuldade estrutural dos serviços em garantir os recursos necessários para o desempenho das atividades, bem como das condições físicas de trabalho e da própria segurança dos profissionais. Assim, mesmo em condições adversas de trabalho, com pouco suporte e limitações, as agentes são extremamente exigidas. Neste sentido, aponta-se para a necessidade de supervisão dos casos de violência por um profissional especializado e a capacitação das agentes e dos demais profissionais da equipe, em uma perspectiva direcionada à abordagem das violências.

Em termos de formação, os profissionais de saúde destacam o desenvolvimento de uma escuta ativa, qualificada e não preconceituosa da mulher, já que a demanda de violência não se apresenta como queixa primária e, os profissionais, por sua vez, submersos a rotina de trabalho, não dão a devida atenção às demandas não manifestadas.

Quanto à capacitação, os profissionais de saúde apontam além da abordagem às violências, um treinamento voltado à notificação compulsória, levando-se em consideração sua finalidade, relevância e o preenchimento dessa ficha. Outro ponto recomendado como demanda de capacitação refere-se à conscientização das mulheres profissionais com relação à gravidade da demanda de violência e suas consequências para a vida da mulher, já que muitas profissionais sofrem ou já sofreram algum tipo de agressão.

Em termos de Políticas Públicas Sociais às mulheres em situação de violência, os profissionais da rede de assistência enfatizam a integração dos serviços de Saúde, Educação e Segurança Pública. Ressaltam que a mulher precisa ser valorizada, apoiada e encorajada a romper com o ciclo de violência, por meio do incentivo à vida social, com espaços de escuta e atividade física na comunidade, pelo acesso aos serviços de saúde e oportunidades de emprego. De igual modo, mencionam a retomada de uma cultura de família, de respeito aos pais e professores, considerando a importância da educação em casa e posteriormente nas escolas, como meio de conscientizar e estabelecer o conceito de cidadania no indivíduo.

Outro ponto destacado refere-se à inclusão do debate das relações de gênero nas escolas de modo a questionar a naturalização das representações atribuídas ao feminino e ao masculino, bem como a valorizar a diversidade e pluralidade dos indivíduos, além do incentivo à promoção de políticas de igualdade e conscientização das mulheres quanto à violência sofrida. Aponta-se também para o investimento na educação e reabilitação de homens e mulheres, tanto do agressor, para que rompa com o comportamento violento, como da mulher, para que não banalize a violência.

Vale ressaltar que a discussão de gênero nas escolas é amplamente debatida e não existe um consenso entre as autoridades. Em 2014, o Plano Nacional de Educação (PNE) foi 
aprovado sem o trecho que falava sobre gênero e em 2017 foram retirados os termos "gênero" e "orientação sexual” da Base Nacional Comum Curricular (BNCC).

No município de Jundiaí, por exemplo, foi aprovado em outubro de 2017 a Lei "Escola Sem Partido", a qual visa proibir a doutrinação política e ideológica em sala de aula e nos livros didáticos. No entanto, em novembro de 2017 foi concedida uma liminar que suspendeu os efeitos da Lei no município.

Neste sentido, o projeto Gênero e Diversidade na Escola (GDE), destinado à formação de profissionais da área de educação nas temáticas de gênero, sexualidade, orientação sexual e relações étnico-raciais destaca-se como importante iniciativa do Governo Federal para a implementação de políticas públicas promotoras da igualdade e do respeito à diversidade $\mathrm{e}$ aos direitos humanos.

Esse projeto que visa à formação dos profissionais da área da educação poderia ser pensado e adaptado inclusive para os serviços de saúde. Vale ressaltar que todo o Núcleo de Políticas Públicas do município de Jundiaí tem se mobilizado e articulado juntamente com os serviços da rede de assistência para a formulação de uma política municipal às mulheres em situação de violência. Dentre as propostas para o município, aponta-se a criação de um Centro de Referência Especializado às Mulheres em situação de violência. Neste sentido, os profissionais de saúde sugerem a criação de um serviço intermediário, na própria atenção básica, similar ao CONFAD, para acolher demandas sociofamiliares, como a violência.

Em termos de políticas públicas, destaca-se a importância da sinalização dos serviços oferecidos às mulheres nas UBSF, bem como a construção de um guia que contemple os serviços da rede de assistência às mulheres em situação de violência. Em 2017, a Prefeitura de Jundiaí lançou um aplicativo de celular com mais de 80 serviços disponibilizados ao usuário, dentre eles, a denúncia do assédio sexual em ônibus. A divulgação do aplicativo, assim como da campanha contra o assédio sexual em ônibus, concretizou-se por meio de cartazes afixados no transporte público.

Essa divulgação dos serviços, ações e procedimentos, além da mobilização dos movimentos sociais junto à sociedade são fundamentais para dar visibilidade à violência doméstica contra a mulher. Neste sentido, a cidade de Jundiaí participa pela primeira vez em 27 de novembro de 2017 da campanha internacional pelo fim da violência contra a mulher. Foram 16 dias de ativismo com uma programação diversificada com ênfase nos direitos humanos, nos direitos das mulheres e no empoderamento.

Com relação ao engajamento dos serviços de saúde em termos de mobilização social, aponta-se para sua participação na transformação da cultura, principalmente o que concerne às 
representações de gênero. Dessa forma, a realização de grupos nas UBSF poderá contribuir para a discussão e reflexão de novos caminhos. Essa discussão, entretanto, não tem como finalidade priorizar a experiência particular de violência de cada mulher ou a educação voltada exclusivamente à comunidade, mas sim, uma construção articulada com os movimentos sociais junto à sociedade sobre essa possibilidade de mudança.

Dentre as conquistas do município de Jundiaí para o enfrentamento das violências, destaca-se a Lei n. 8.800 de Junho de 2017, referente à notificação compulsória a todos os profissionais da rede de assistência. Verifica-se, porém, a necessidade de sua divulgação entre os profissionais. Quanto a Lei Maria da Penha, as agentes comunitárias e demais profissionais de saúde apontam para a importância da divulgação dos casos bem-sucedidos assim, como dos direitos das mulheres.

Embora o município de Jundiaí avance nas ações para o enfrentamento das violências, em contrapartida, em 2018, o governo de Michel Temer adotou medidas, como a Emenda Constitucional 95, conhecida anteriormente como PEC do Teto, que visa à diminuição dos gastos públicos em geral, incluindo a saúde. A diminuição de verba, consequentemente, coloca em cheque a continuidade do SUS em sua atual configuração.

Essa fragilidade do SUS tem levado, por sua vez, os serviços à terceirização. Desse modo, se a violência contra a mulher enfrenta vários cenários, ela enfrenta inclusive o cenário das organizações dos serviços, como por exemplo, a terceirização. Então, não é apenas a capacitação dos profissionais de saúde que irá resolver essa questão, mas a compreensão da complexidade desse problema, considerando dentre outros elementos a burocratização dos serviços, direcionada a priorizar dados estatísticos e o preenchimento de relatórios para a liberação de verbas em detrimento da valorização do capital humano e das tecnologias leves, com ênfase nos resultados qualitativos.

Outro problema da burocratização dos serviços é que, por trás dessa ideia, também está implícito o mau uso das verbas públicas, tanto na saúde, na educação, na segurança, como em outras áreas de responsabilidade do Estado. A corrupção encontra-se em todas as esferas públicas, municipal, estadual e federal, o que, em grande parte, contribui para o sucateamento do SUS.

Sendo assim, a formação dos profissionais de saúde não pode ser pensada descolada de um contexto adverso de organização do serviço, que envolve a terceirização, a precarização, a corrupção e a rotina de trabalho estressante voltada para metas, as quais muitas vezes o agente comunitário de saúde não consegue cumprir. Neste sentido, vale ressaltar que a burocratização dos serviços tem contribuído para o adoecimento dos 
profissionais de saúde. A Síndrome de Burnout ou Síndrome do Esgotamento Profissional, desenvolvida em decorrência da tensão emocional e estresse crônico provocado pelas condições de trabalho físicas, emocionais e psicológicas, é uma das consequências sob a qual os profissionais de saúde encontram-se sujeitos. Nesta perspectiva, aponta-se não apenas à necessidade de formação, mas também à necessidade de cuidados, apoio, suporte e ajuda que tanto as agentes como os demais profissionais da equipe carecem. 


\section{REFERÊNCIAS}

Akerman $\mathrm{M}$ et al. "Dissonâncias entre as competências ofertadas pelos agentes comunitários de saúde e as expectativas da população". In: Akerman M, Morais CK, organizadores. PETSaúde da Faculdade de Medicina do ABC: Programa de Educação pelo Trabalho para a Saúde: resultado de projetos aplicados. Coleção temas interdisciplinares (9). $2^{\mathrm{a}}$ ed. São Paulo: Mídia Alternativa Comunicação e Editora; 2012. p. 49-76.

Akerman M. Estresse, ansiedade e depressão em estudantes de medicina: problema de saúde pública? In: Baladassin S, organizador. Atendimento psicológico aos estudantes de medicina: técnica e ética. São Paulo: Edipro; 2012. p. 25-30.

Alves RA, Pinto LMN, Silveira AM, Oliveira GL, Melo EM de. Homens vítimas e autores de violência: a corrosão do espaço público e a perda da condição humana. Interface. 2012; 16(43): 871-883.

Agência Patrícia Galvão [homepage na internet]. Após audiênca pública, CCJ do Senado vota amanhã PL que altera a Lei Maria da Penha [acesso em 28 jun 2016]. Disponível em: http://agenciapatriciagalvao.org.br/violencia/ccj-do-senado-vota-amanha-pl-que-altera-leimaria-da-penha/

Agência Patrícia Galvão [homepage na internet]. Cultura e raízes da violência contra as mulheres. In: Dossiê violência contra as mulheres [acesso em 30 jun 2017]. Disponível em: http://www.agenciapatriciagalvao.org.br/dossie/violencias/cultura-e-raizes-da-violencia/

Araújo M de F, Martins EJS, Santos AL dos. Violência de gênero e violência contra a mulher. In: Araújo M de F, Mattioli OC, organizadores. Gênero e violência. São Paulo: Arte e Ciência; 2004.

Aragão S. A vitimização da mulher. In: Leal CB, Júnior HP, organizadores. Violência e vitimização: a face sombria do cotidiano. Belo Horizonte: Del Rei; 2001.

Azambuja MPR de, Nogueira C. Introdução à violência contra as mulheres como um problema de direitos humanos e de saúde pública. Saúde Soc. 2008; 17(3): 101-112.

Barbour R. Grupos Focais. Porto Alegre: Artmed; 2009.

Bardin L. Análise de Conteúdo. Lisboa: Edições 70; 2009.

Batista KBC. Violência contra a mulher e programa saúde da família: a emergência da demanda na visão dos profissionais. In: Vilella W, Monteiro S, organizadores. Gênero e saúde: programa saúde da família em questão. São Paulo: Associação Brasileira de Saúde Coletiva - Abrasco; Fundo de População das Nações Unidas — UNFPA; 2005.

Bauman Z. Amor Líquido: sobre a fragilidade dos laços humanos. Rio de Janeiro: Zahar; 2004. 
Bauman Z. Medo líquido. Rio de Janeiro: Zahar; 2008. p. 8.

Barreto M, Heloani R. Violência, saúde e trabalho: a intolerância e o assédio moral nas relações laborais. Serv. Soc. Soc. 2015; 123: 544-561.

Barus-Michel J. A violência complexa, paradoxal e multívoca. In: Souza Mde, Martins FMMC, Araújo JNG de, organizadores. Dimensões da violência: conhecimento, subjetividade e sofrimento psíquico. São Paulo: Casa do Psicólogo; 2011.

Bedone AJ, Fagundes A. Atendimento integral às mulheres vítimas de violência sexual: Centro de Assistência Integral à Saúde da Mulher. Cad. Saúde Pública. 2007; 23(2): 465-9.

Berenstein I. El sujeto y el outro de la ausência a la presencia. Buenos Aires: Paidós Psicologia Profunda; 2001.

Berger SMD, Barbosa RHS, Soares CT, Bezerra CM. Formação de agentes comunitários de saúde para o enfrentamento da violência de gênero: contribuições da Educação Popular e da pedagogia feminina. Interface. 2014; 18(supl.1): 1241-1254.

Bezerra JRB. A violência como degradação do poder e da agressividade. In: Kunzler F, organizador. Pensando a violência com Freud. A brasileira na cultura. Porto Alegre: Sociedade Brasileira de Psicanálise de Porto Alegre; 2005.

Bourdieu P. A dominação masculina. Rev. Educação e Realidade. 1995; 20(2): 133-184.

Bourdieu P. A dominação masculina. Rio de Janeiro: Bertrand Brasil; 2014.

Brasil. Lei no 10.507 de 10 de julho de 2002. Cria a profissão de agente comunitário de saúde e dá outras providências. Brasília; 2002a.

Brasil. Lei $\mathrm{n}^{\mathrm{o}} 10.406$ de 10 de janeiro de 2002. Lei de introdução às normas do direito brasileiro. Institui o código civil. Brasília; 2002b [acesso em 02 de maio de 2018]. Disponível em: http://www.planalto.gov.br/ccivil_03/leis/2002/L10406compilada.htm

Brasil. Lei $\mathrm{n}^{\mathrm{o}}$ 11.340, de 07 de agosto de 2006. Cria mecanismos para coibir a violência doméstica contra a mulher e dá outras providências. Brasília (DF): Presidência da República; 2006 [acesso em 07 de março de 2018]. Disponível em: http://www.planalto.gov.br/ccivil_03/_ato2004-2006/2006/lei/111340.htm

Brasil. Pacto nacional pelo enfrentamento à violência contra as mulheres. Secretaria nacional de enfrentamento à violência contra as mulheres. Secretaria de políticas para as mulheres. Brasília; 2011.

Cabral F, Díaz M. Relações de gênero. In: Secretaria Municipal de educação de Belo Horizonte; Fundação Odebrecht. Cadernos afetividade e sexualidade na educação: um novo olhar. Belo Horizonte: Gráfica e Editora Rona Ltda; 1998. p. 142-150.

Campos CH de. A CPMI da violência contra a mulher e a implementação da lei Maria da Penha. Estudos Feministas. 2015; 23(2): 519-531. 
Cardoso AS, Nascimento, MC do. Comunicação no Programa Saúde da Família: o agente de saúde como elo integrador entre a equipe e a comunidade. Ciência \& Saúde Coletiva. 2010; 15 (Supl. 1): 1509-20.

Carnassale VD. Notificação de violência contra a mulher: conhecer para intervir na realidade [dissertação de mestrado]. São Paulo: Universidade de São Paulo, Escola de Enfermagem; 2012.

Castells M. O poder da identidade. São Paulo: Paz e terra; 1999.

Chauí M. Ética, política e violência. In: Camacho T., organizador. Ensaios sobre violência. Vitória: Edufes; 2003.

Cordeiro H. SUS - Sistema Único de Saúde. Rio de Janeiro: Ayuri; 2005.

Costa HOG. A problematização da violência como experiência de ensinar saúde. Interface. 1999; 3(5): 63-74.

Couto MT, Schraiber LB, D’Oliveira AFPL, Kiss LB. Concepções de gênero entre homens e mulheres de baixa renda e escolaridade acerca da violência contra a mulher, São Paulo, Brasil. Ciência e Saúde Ciletiva. 2007; 11(Sup): 1323-1332.

Cruz Neto O, Moreira MR, Sucena LFM. Grupos Focais e Pesquisa Social Qualitativa: o debate orientado como técnica de investigação. Trabalho apresentado no XIII Encontro da Associação Brasileira de Estudos Populacionais, realizado em Ouro Preto, Minas Gerais, Brasil, de 4 a 8 de novembro de 2002.

D’Oliveira AFP, Schraiber LB. Mulheres em situação de violência: entre rotas críticas e redes intersetoriais de atenção. Rev. Med. 2013; 92(2): 134-40, p.136.

De Ferrante FG, Santos MAdos, Vieira EM. Percepção dos médicos das unidades básicas de saúde da cidade de Ribeirão Preto, São Paulo. Interface. 2009; 13(31).

Debert GG, Gregori MF. Violência e gênero: novas propostas, velhos dilemas. Rev. Bras. Ciências Sociais. 2008; 23(66): 165-211.

Deslandes SF, Pesce RP. Trabalhadores de Saúde e Educação: lidando com violências no cotidiano. In: Njaine K, Assis SGD, Constantino P, organizadores. Impactos da violência na saúde. Rio de Janeiro: Fundação Oswaldo Cruz: Educação à distância da Escola Nacional de Saúde Pública Sérgio Arouca; 2009.

Diniz GRS, Pondaag M. Explorando significados do silêncio e do segredo nos contextos de violência doméstica. In: Barus-Maluschke JSNF, Maluschke G, Hermanns K, organizadores. Direitos humanos e violência: desafios da ciência e da prática. Fortaleza: Fundação Konrad Adenauer; 2004.

Diniz GRS, Pondaag M. A face oculta da violência contra a mulher. In: Alemida AMO et al., organizadores. Violência, exclusão social e desenvolvimento humano: estudos em representações sociais. Brasília: UnB; 2006. Cap. 10, p.233-59. 
Duarte LR, Silva DSJR da, Cardoso SH. Construindo um programa de educação com agentes comunitários de saúde. Interface. 2007; 11(23): 439-47.

Escola Nacional de Saúde Pública Sérgio Arouca [homepage na internet]. Carta de repúdio às portarias GM/MS 958 e 959/2016 [acesso em 25 jun 2016]. Disponível em: http://www.ensp.fiocruz.br/portal-ensp/informe/site/materia/detalhe/39669

Estacheski DLT, Medeiros TG de. Atualidade da obra de Mary Wollstonecraft. Rer. Estud. Fem. 2017; 25(1): 375-378.

Ferreira Neto JL. Psicologia, políticas públicas e o SUS. São Paulo-Belo Horizonte: EscutaFapeming; 2011.

Feuerwerker LMC. Além do Discurso de Mudança na Educação Médica. Rio de Janeiro: Hucitec/Rede Unida/Associação Brasileira de Educação Médica; 2002.

Feuerwerker LMC. Cuidar em saúde. In: Ferla AA et al. organizadores. VER-SUS Brasil: cadernos de textos. Porto Alegre: Rede Unida; 2013.

Feuerwerker LMC. Coleção Micropolítica do Trabalho e o Cuidado em Saúde. Porto Alegre: Rede Unida; 2014.

FLACSO/OPAS-OMS/ONU Mulheres/SPM. Faculdade Latino Americana de Ciências Sociais, Organização Pan-America da Saúde - Organização Mundial da Saúde, ONU Mulheres, Secretaria Especial de Políticas para as Mulheres. Mapa da violência 2015: homicídios de mulheres no Brasil; 2015.

Flick, U. Introdução à pesquisa qualitativa. Porto Alegre: Artmed; 2009.

Fonseca RMGS da, Leal AERB, Skubs T, Guedes RN, Egry EY. Violência doméstica contra a mulher na visão do agente comunitário de saúde. Rev. Latino-am Enfermagem. 2009; 17(6): 974-980.

Fonseca DH da, Ribeiro CG, Leal NSB. Violência doméstica contra a mulher: realidades e representações sociais. Psicologia e Sociedade. 2012; 24(2): 307-314.

Freire, P. Educação como prática de liberdade. Rio de Janeiro: Paz e Terra; 1974.

Fundação Perseu Abramo. A mulher brasileira nos espaços públicos e privados. São Paulo: Autor; 2001.

Grossi MP. Cenas e queixas: um estudo sobre mulheres, relações violentas e a prática feminista. Rio de Janeiro: Paz e Terra/ANPOCS; 1993.

Guedes JS, Santos RMB dos, Di Lorenzo RAV. A implantação do Programa de Saúde da Família no estado de São Paulo (1995-2002). Saúde e Sociedade. 2011; 20(4): 875-883.

Guimarães MC, Pedroza RLS. Violência contra a mulher: problematizando definições teóricas, filosóficas e jurídicas. Psicologia e Sociedade. 2015; 27(2): 256-266. 
Hesler LZ, Costa MC, Resta DG, Colomé ICS. Violência contra as mulheres na perspectiva dos agentes comunitários de saúde. Rev. Gaúcha Enferm. 2013; 34(1): 180-186.

Iara CP. Possibilidades e limites do trabalho de agentes comunitários de saúde para a promoção de saúde [Dissertação de doutorado]. São Paulo: Universidade de São Paulo, Escola de Enfermagem; 2015.

Jodelet D. As representações sociais. Rio de Janeiro: EdUERJ; 2001. p. 22.

Kiss LB, Schraiber LB. Temas médicos sociais e a intervenção em saúde: a violência contra mulheres nos discursos dos profissionais de saúde. Ciência e Saúde Coletiva. 2011; 16(3): 1943-1952.

Krueger, RA. Analyzing and reporting focus group results. California: Sage; 1998.

Krueger, RA. Developing questions for focus groups. California: Sage; 1998.

Krueger, RA. Moderating focus groups. California: Sage; 1998.

Leal SMC, Lopes MJM, Gaspar MFM. Representações sociais da violência contra a mulher na perspectiva da enfermagem. Interface. 2011; 15(37): 409-24.

Louro GL. Nas redes do conceito de gênero. In: Lopes MJM, Meyer DE, Waldow VR, organizadores. Gênero e saúde. Porto Alegre: Artes Médicas; 1996.

Louro GL. Gênero, sexualidade e educação: uma perspectiva pós-estruturalista. Rio de Janeiro: Vozes; 2014. p. 28.

Lunardelo SR. O trabalho do agente comunitário de saúde nos núcleos de saúde da família [Dissertação de mestrado]. Ribeirão Preto: Universidade de São Paulo, Escola de Enfermagem; 2004.

Merhy EE. A perda da dimensão cuidadora na produção de saúde: uma discussão do modelo assistencial e da intervenção no seu modo de trabalhar a assistência. In: Mehry EE et al., organizadores. Sistema Único de Saúde em Belo Horizonte: reescrevendo o público. São Paulo: Xamã; 1998.

Merhy EE. Saúde: cartografia do trabalho vivo em ato. São Paulo: Hucitec; 2002.

Merhy EE, Feuerwerker LCM. Novo olhar sobre as tecnologias de saúde: uma necessidade contemporânea. In: Mandarino ACS, Gomberg E, organizadores. Novas tecnologias e saúde. Salvador: EdUFBa; 2009.

Minayo MCS. A violência social sob a perspectiva da saúde pública. Cad. Saúde Pública. 1994; 10 (suppl.1): 7-18.

Minayo MCS. Entrevistada: Cecília Minayo. Conasems. 2004; (4): 7-13. (Entrevistador: G. de Paula). 
Minayo MCS. A violência dramatiza causas. In: Minayo MCS, Souza ER, organizadores. Violência sob o olhar da saúde: infrapolítica da contemporaneidade brasileira. Rio de Janeiro: Fiocruz; 2006.

Minayo MCS. Palavra, inteirações e representações sociais. In: Minayo MCS, organizador. O desafio do conhecimento: pesquisa qualitativa em saúde. São Paulo: Hucitec; 2008. p. 219.

Ministério da Saúde (BR). Portaria GM n. 1.886, de 18 de dezembro de 1997. Aprova as Normas e Diretrizes do Programa de Agentes Comunitários de Saúde e do Programa de Saúde da Família. Diário Oficial da República Federativa do Brasil. Brasília (DF): Ministério da Saúde; 1997. p. 11-13.

Ministério da Saúde (BR). Secretaria de Políticas de Saúde. Violência Intrafamiliar: Orientações para a Prática em Serviço. Brasília (DF): Ministério da Saúde; 2001a.

Ministério da Saúde (BR). Departamento de Atenção Básica. Guia Prático do Programa de Saúde da Família. Brasília (DF): Ministério da Saúde; 2001b.

Ministério da Saúde (BR). Secretaria de Gestão do Trabalho e da Educação em Saúde. Departamento de Gestão da Educação na Saúde. Política de educação e desenvolvimento para o SUS: caminhos para a educação permanente em saúde. Brasília: Ministério da Saúde; 2003.

Ministério da Saúde (BR). Portaria n. 198, de 13 de fevereiro de 2004. Institui a Política Nacional de Educação Permanente em Saúde como estratégia do Sistema Único de Saúde para a formação e desenvolvimento de trabalhadores para o setor e dá outras providências. Diário Oficial da República Federativa do Brasil. Brasília (DF): Ministério da Saúde; 2004a.

Ministério da Saúde (BR). Secretaria de Gestão do Trabalho e da Educação na Saúde. Departamento de Gestão da Educação na Saúde. Referencial curricular para o curso técnico de agente comunitário de saúde. Brasília (DF): Ministério da Saúde; 2004b. p.16.

Ministério da Saúde (BR). Secretaria de Gestão do Trabalho e da Educação na Saúde. Dinâmica das graduações em Saúde no Brasil: subsídios para uma política de recursos humanos. Brasília (DF): Ministério da Saúde; 2006.

Ministério da Saúde (BR). Enfrentamento a Violência Contra a Mulher: balanço de ações 2006-2007. Brasília (DF): Secretaria Especial de Políticas para as Mulheres; 2007.

Ministério da Saúde (BR). Secretaria de atenção à saúde. Política Nacional de Humanização da Atenção e Gestão do SUS. O Humaniza SUS na atenção básica. Brasília (DF): Ministério da Saúde; 2009.

Ministério da Saúde (BR). Secretaria de atenção à saúde. Política Nacional de Atenção Básica. Das atribuições específicas dos agentes comunitários de saúde. Brasília (DF): Ministério da Saúde; 2012.

Ministério da Saúde (BR). Secretaria de atenção à saúde. Política Nacional de Humanização. Princípios e Diretrizes. Brasília (DF): Ministério da Saúde; 2013. 
Ministério da Saúde (BR). Portaria n. 1.271, de 06 de junho de 2014. Define a Lista Nacional de Notificação Compulsória de doenças, agravos e eventos de saúde pública nos serviços de saúde públicos e privados em todo o território nacional, nos termos do anexo, e dá outras providências. Brasília (DF): Ministério da Saúde; 2014.

Ministério Público do Estado de São Paulo (BR). Mulher, vire a página. São Paulo: Grupo de Atuação Especial de Enfrentamento à Violência Doméstica; 2011.

Moore HL. Feminism and Anthropology. Cambridge: Polity Press, 1988.

Moreira MIC, Ribeiro SF, Costa KF. Violência contra a mulher na esfera conjugal: jogo de espelhos. In: Costa A, Bruschini C, organizadores. Entre a Virtude e o Pecado. Rio/ S. Paulo: Ed. Rosa dos Tempos/ F. Carlos Chagas; 1992.

Moreira TNF, Martins CL, Feuerwerker LMC, Schraiber LB. A construção do cuidado: o atendimento às situações de violência doméstica por equipes de Saúde da Família. Saúde Soc. 2014; 23(3): 814-827.

Morgan DL. Planning focus group. California: Sage; 1998.

Moscovici S. Des représentations collectives aux représentations sociales. In: Jodelet D, organisateur. Les Représentations Sociales. Paris: Presses Universitaires de France; 1989.

Moscovici S. Representações Sociais: investigações em psicologia social. Rio de Janeiro: Vozes; 2007. p. 35, 42 e 210.

Nóbrega VHM, Miranda FAN de. Da vulnerabilidade à resiliência: o processo de enfrentamento da mulher agredida. In: Vieira LJEdeS, Silva RM da, Lira SVG, organizadores. Violência e saúde: na diversidade dos escritos acadêmicos. São Paulo: Hucitec Editora; 2013.

Nascimento ICA do. Da (In) Aplicabilidade da lei Maria da Penha aos homens vítimas de violência doméstica. Rio de Janeiro: Universidade Cândido Mendes; 2013 [acesso em 12 de set 2018]. Disponível em: https://ysabeu1.jusbrasil.com.br/artigos/111575548/da-inaplicabilidade-da-lei-maria-da-penha-aos-homens-vitimas-de-violencia-domestica

Nunes MO, Trad LB, Almeida BA, Homem CR, Melo MCIC. O agente comunitário de saúde: construção da identidade desse personagem híbrido e polifônico. Cad. Saúde Pública. 2002; 18 (6): 1639-46.

OEA. Organização dos Estados Americanos. Convenção Interamericana para Prevenir, Punir e Erradicar a Violência Contra a Mulher; 1994. [Internet]. [acesso em 2015-10-05]. Disponível em: http://www.oas.org/juridico/portuguese/treaties/A-61.htm

Oliveira EM. Fórum: violência sexual em saúde. Introdução. Cad. Saúde Pública. 2007; 23 (2): 455-8.

Oliveira CC, Almeida MAS, Morita I. Violência e saúde: Concepções de profissionais de uma unidade básica de saúde. Rev. bras. educ. med. 2011; 35 (3): 412-20. 
Oliveira RNG de, Fonseca RMGS da. A violência como objeto de pesquisa e intervenção no campo da saúde: uma análise a partir da produção do grupo de pesquisa gênero, saúde e enfermagem. Rev. Esc. Enferm. USP. 2014; 48(Esp2): 32-39.

OMS. Organização Mundial de Saúde. Relatório Mundial sobre violência e saúde. Genebra: OMS; 2002.

ONU. Organização das Nações Unidas. Convenção sobre a Eliminação de Todas as Formas de Discriminação contra a Mulher; 1979. [Internet]. [acesso em 2015-10-05]. Disponível em: http://www.pge.sp.gov.br/centrodeestudos/bibliotecavirtual/instrumentos/discrimulher.htm

OPAS. Organização Pan-Americana da Saúde. Prácticas Sociales y Salud Publica. In: OPS La salud publica em las Américas: nuevos conceptos, análisis del desempeño y bases para la acción. Washington DC: OPS; 2002.

Pedro, JM. Traduzindo o debate: o uso da categoria gênero na pesquisa histórica. História. 2005; 24(1): 77-98.

Pedrosa JIS, Teles JBM. Consenso e diferenças em equipes do Programa Saúde da Família. Rev. Saúde Pública. 2001; 35 (3): 303-11.

Penha JC da, Aquino P de S, Sousa PSA de, Jorge MSB, Verde IL, Sampaio HA de C. Violência contra a mulher: riscos e vulnerabilidades de prostitutas. In: Vieira LJE de S, Silva RM da, Lira SVG organizadores. Violência e saúde: na diversidade dos escritos acadêmicos. São Paulo: Hucitec Editora; 2013.

Polit DF, Beck CT. Fundamentos da pesquisa em enfermagem. $7^{\mathrm{a}}$ ed Porto Alegre: Artmed; 2011.

Pope C, Mays N. Pesquisa qualitativa na atenção à saúde. Porto Alegre: Artmed; 2009.

Prefeitura de Curitiba. Casa da Mulher Brasileira de Curitiba [Internet] [acesso em 2018-0320]. Disponível em: http://www.curitiba.pr.gov.br/servicos/cidadao/casa-da-mulher-brasileirade-curitiba/726

Prefeitura de Jundiaí. Perfil [Internet] [acesso em 2016a-01-10]. Disponível em: http://www.jundiai.sp.gov.br/a-cidade/perfil/

Prefeitura de Jundiaí. História [Internet] [acesso em 2016b-01-10]. Disponível em: http://www.jundiai.sp.gov.br/a-cidade/historia/

Prefeitura de Jundiaí. Secretaria de saúde [Internet] [acesso em 2017c-02-01]. Disponível em: http://www.jundiai.sp.gov.br/saude/

Prefeitura de Jundiaí. Secretaria de assistência e desenvolvimento social [Internet] [acesso em 2017d-02-01]. Disponível em: http://www.jundiai.sp.gov.br/assistencia-e-desenvolvimentosocial/ 
Prefeitura de Jundiaí. Lei N. ${ }^{\circ} 8.800$ de 12 de junho de 2017. Institui notificação compulsória de violência nas categorias que especifica [Internet] [acesso em 2018-05-20] Disponível em: https://leismunicipais.com.br/SP/JUNDIAI/LEI-8800-2017-JUNDIAI-SP.pdf

Prefeitura de Jundiaí. Plano municipal de saúde 2018-2021 [Internet] [acesso em 2018-05-20] Disponível em:_https://jundiai.sp.gov.br/saude/wp-content/uploads/sites/17/2017/09/planomunicipal-de-saude-jundiai-2018-2021.pdf

Prefeitura de Recife. Recife comemora o dia nacional do agente de saúde. Notícias [Internet] [acesso em 2018-04-30]. Disponível em: http://www2.recife.pe.gov.br/noticias/03/10/2017/recife-comemora-o-dia-nacional-dosagentes-de-saude

Prefeitura de São Paulo. Secretaria de assistência e desenvolvimento social. Mulheres vítimas de violência [Internet] [acesso em 2018-03-20]. Disponível em: http://www.prefeitura.sp.gov.br/cidade/secretarias/assistencia_social. php?p=3212

Rocha NHN, Bevilacqua PD, Barletto M. Metodologias participativas e educação permanente na formação de agentes comunitários/as de saúde. Trab. Educ. Saúde. 2015; 13(3): 597-615.

Rosa R, Boing AF, Schraiber LB, Coelho EBS. Violência: Conceitos e Vivências entre acadêmicos da área de saúde. Interface. 2010; 14(32): 81-90.

Roschke MAC. Educação permanente - compreensão: alguns conceitos e características essenciais. Olho Mágico. 2006; 13(3): 32-5.

Rubin GT. The traffic in women: Notes on the "political economy" of sex. In: Reiter RR. organizer. Toward na Anthropology of women. Nova Iorque: Monthly Review Press; 1975.

Saliba O, Garbin CAS, Garbin AJI, Dossi AP. Responsabilidade do profissional de saúde sobre a notificação de casos de violência doméstica. Rev. Saúde Pública. 2007; 41(3): 472-7.

Santos RLA dos, Adorno RCF, Barbosa S, Diniz SG. Agentes comunitários de saúde e suas inquietações com as masculinidades: um problema de gênero. In: Adorno RCF, Alvarenga AT de, Vasconcellos MPC, organizadores. Jovens trajetórias, masculinidades e direitos. São Paulo: Fapesp: Editora da Universidade de São Paulo; 2005.

Santos MA dos, Vieira EM. Recursos sociais para apoio às mulheres em situação de violência em Ribeirão Preto, SP, na perspectiva de informantes-chave. Interface. 2011; 15(36): 93-108.

Scaranto CAA, Biazevic MGH, Michel-Crosato E. Percepção dos agentes comunitários de saúde sobre a violência doméstica contra a mulher. Psicologia Ciência e Profissão. 2007; 27(4): 694-705.

Schraiber LB, D’Oliveira AFPL. Violência contra mulheres: interfaces com a saúde. Interface. 1999; 3(5): 11-26.

Schraiber LB. Violência contra as mulheres e políticas de saúde no Brasil: o que podem fazer os serviços de saúde. Revista USP. 2001; n.51: 104-113. 
Schraiber LB, D’Oliveira AFPL, Falcão MTC, Figueiredo WS. Violência dói e não é direito. São Paulo: Editora Unesp; 2005.

Schraiber LB, D'Oliveira AFPL, Portella AP, Menicucci E. Violência de gênero no campo da Saúde Coletiva: conquistas e desafios. Ciência e Saúde Coletiva. 2009; 14(4): 1019-1027.

Scott JW. Gênero: uma categoria útil para análise histórica. Educação e Realidade. 1995; 20(2): 71-99. p. 72.

Scott P. Gênero, família e comunidades: observações e aportes teóricos sobre o programa saúde da família. In: Vilella W, Monteiro S, organizadores. Gênero e saúde: programa saúde da família em questão. São Paulo: Associação Brasileira de Saúde Coletiva - Abrasco; Fundo de População das Nações Unidas — UNFPA; 2005.

Seligman MEP. Felicidade autêntica: usando a psicologia positiva para a realização permanente. Rio de Janeiro: Objetiva; 2009. p. 162.

Silva ATC da, Menezes PR. Esgotamento profissional e transtornos mentais comuns em agentes comunitários de saúde. Rev. de Saúde Pública. 2008; 42(5): 921-929.

Silva SG da. Preconceito e discriminação: as bases da violência contra a mulher. Psicologia Ciência e Profissão. 2010; 30 (3): 556-571.

Silva EB da, Padoin SM de M, Vianna LAC. Mulher em situação de violência: limites da assistência. Ciência e Saúde Coletiva. 2015a; 20(1): 249-258.

Silva CD et al. Representação social da violência doméstica contra a mulher entre técnicos de enfermagem e agentes comunitários. Rev. Esc. Enferm. USP. 2015b; 49(1): 22-29.

Spink MJP. O conceito de representação social na abordagem psicossocial. Cad. Saúde Pública. 1993; 9(3): 283-299.

Tavares GA. A comunicação entre os agentes comunitários de saúde e usuários do Programa de Saúde da Família [Dissertação de Especialização]. Curitiba: Universidade Federal do Paraná. Curitiba; 2002.

Teles MAA. O que são direitos humanos das mulheres. São Paulo: Brasiliense; 2007.

Tesser CD, Neto PP, Campos GWS. Acolhimento e (des)medicalização social: um desafio para as equipes de saúde da família. Ciênc. Saúde Coletiva. 2010; 15 (suppl 3): 3615-3624.

Tomas JBC. O Agente Comunitário de Saúde não deve ser um "Super Herói". Interface. 2002; 6(10): 75-94.

Trad LAB, Bastos ACS. O impacto sócio-cultural do Programa de Saúde da Família (PSF): uma proposta de avaliação. Cad. Saúde Pública. 1998; 14(2): 429-35.

Vasconcelos EM. Educação popular como instrumento de reorientação das estratégias de controle das doenças infecciosas e parasitárias. Cad. Saúde Pública. 1998; 14 (Sup. 2): 39-57. 
Víctora CG, Knauth DR, Hassen MNA. Pesquisa qualitativa em saúde: uma introdução ao tema. Porto Alegre: Tomo; 2000.

Vieira GO, Assis MMA, Nascimento MAA do, Vieira TO. Violência e mortes por causas externas. Rev. Bras. Enferm. 2003; 56(1): 48-51. p. 48.

Walker, LE. The battered woman syndrome. United States: Springer Publishing Company; 1984.

WHO. World Health Organization. Violence and health. Center for Global Nonkilling: First CGNK noncommercial; 2009.

Wollstonecraft M. Reivindicação dos direitos da mulher. Trad. de Ivania Pocinho Motta. São Paulo: Boitempo; 2016. 


\section{APÊNDICE 1 - TERMO DE CONSENTIMENTO LIVRE E ESCLARECIDO}

Você está sendo convidado a participar da pesquisa: "Violência doméstica contra a mulher: representações e práticas do agente comunitário de saúde”, da Faculdade de Saúde Pública da Universidade de São Paulo, na responsabilidade da pesquisadora Adriana Miranda Ferreira Leite, orientada pelo Prof. Dr. Marco Akerman.

O objetivo deste estudo é conhecer as representações e práticas do agente comunitário de saúde ao evidenciar situação de violência doméstica contra a mulher.

Ao aceitar fazer parte deste estudo, você participará de um encontro em grupo ou entrevista individual que serão gravados e transcritos posteriormente para a divulgação na dissertação de mestrado e publicações científicas da pesquisadora.

É garantida a desistência de sua participação da pesquisa a qualquer momento, inclusive sem nenhum motivo, bastando para isso informar sua decisão, sem nenhum tipo de prejuízo. Informamos ainda, que, você não pagará nem será remunerado por sua participação. A participação na pesquisa incorrerá em riscos mínimos, tais como o desconforto pelo tempo de duração do grupo ou pelo conteúdo nele abordado.

Os dados obtidos serão mantidos em local seguro e o participante não será identificado por seu nome, mas sim por um número ou nome fictício, sendo garantida a confidencialidade, o sigilo e a privacidade conforme a Resolução $\mathrm{N}^{\circ} 466$ de 12 de dezembro de 2012, do Conselho Nacional de Saúde.

O Termo de Consentimento Livre e Esclarecido deverá ser assinado por todos os participantes da pesquisa. Caso prefira não assinar, por não querer se identificar, sua decisão será respeitada e poderá, mesmo assim, participar da pesquisa mediante a assinatura de duas testemunhas como alternativa a sua não assinatura do presente Termo de Consentimento Livre e Esclarecido.

Para eventuais dúvidas e esclarecimentos poderá contatar a pesquisadora Adriana Miranda Ferreira Leite, no telefone (11)948486826, ou o Comitê de Ética em Pesquisa da Faculdade de Saúde Pública da Universidade de São Paulo, localizado na Av. Dr. Arnaldo, 715, Cerqueira César - CEP 01246-904, São Paulo, SP - Telefone: (11) 3061-7779 - e-mail: coep@fsp.usp.br 
Declaro que li as informações e recebi todos os esclarecimentos necessários da pesquisadora e concordo em participar do estudo. Recebi uma via deste documento que ficará em meu poder.

São Paulo, de de 2016.

Assinatura do participante:

Assinatura do pesquisador: 


\section{APÊNDICE 2 - PERFIL DO AGENTE COMUNITÁRIO DE SAÚDE}

Faculdade de Saúde Pública da Universidade de São Paulo

Título da Pesquisa: "Violência doméstica contra a mulher: representações e práticas do agente comunitário de saúde"

Pesquisadora: Adriana Miranda Ferreira Leite

Data da entrevista: 12016

Local de trabalho:

Nome do ACS:

Data de Nascimento:

Idade: anos

Tempo de atuação em UBS:

Carga horária semanal:

Cor:

1. branco ( )

2. preto ( )

3. pardo ( )

4. amarelo ( )

5. indígena ( )

Naturalidade:

Tempo de residência em Jundiaí: anos

Estado Civil:

1. união estável ( )

2. $\operatorname{casado}(\mathrm{a})(\mathrm{)}$

3. viúvo(a) ( )

4. divorciado/separado( ) ( )

5. solteiro(a) ( ) 
Escolaridade:

1. analfabeto ( )

2. $1^{\circ}$ grau incompleto ( )

3. $1^{\circ}$ grau completo ( )

4. $2^{\circ}$ grau incompleto ( )

5. $2^{\circ}$ grau completo ( )

6. superior incompleto ( )

7. superior completo ( )

Número de filhos: 


\section{APÊNDICE 3 - ROTEIRO DO COORDENADOR}

\section{ABERTURA- Quebra Gelo}

Nome, idade, tempo de trabalho como ACS

\section{INTRODUÇÃO}

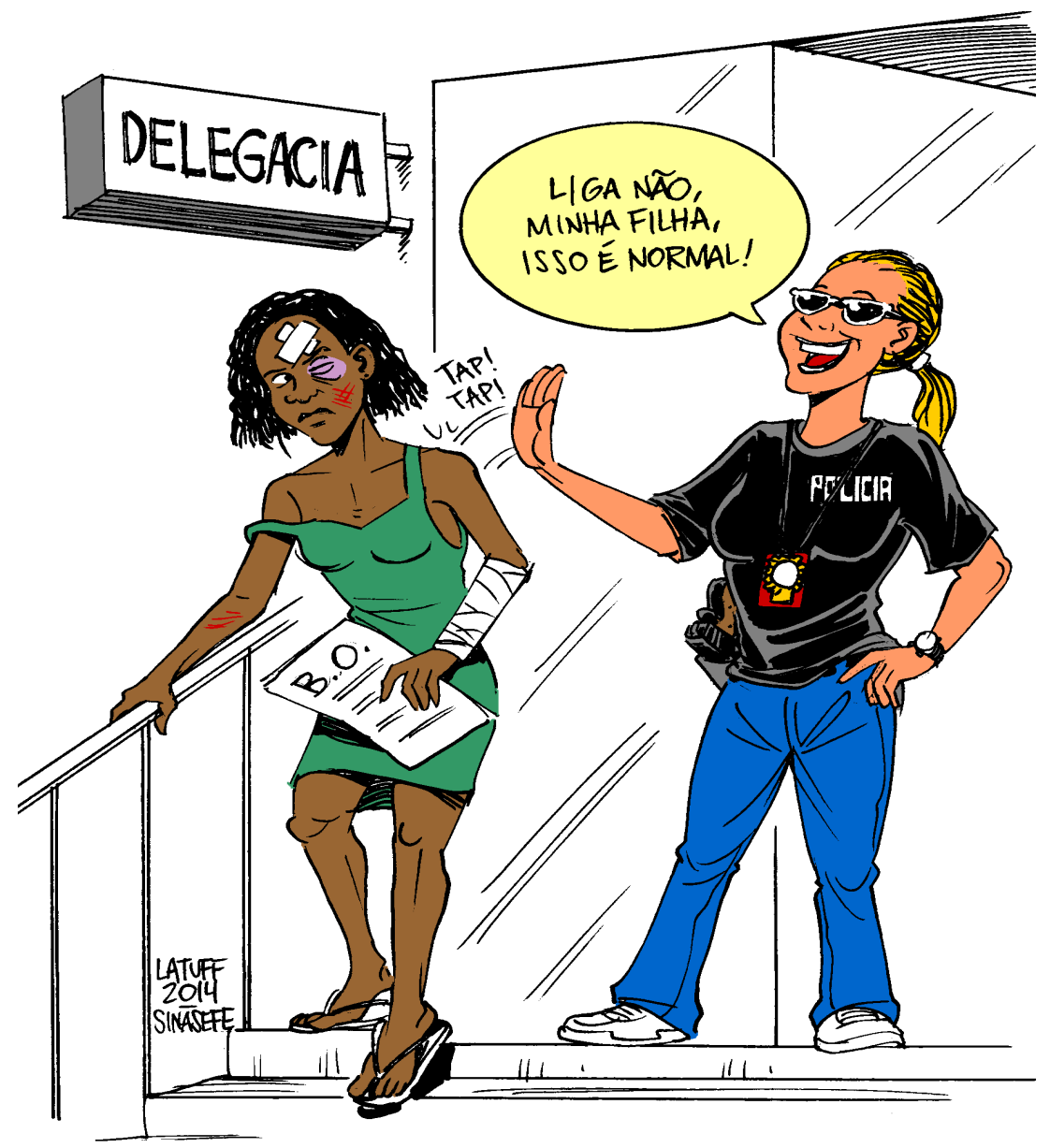

- Ao olhar esta imagem, o que lhe vem em mente?

\section{QUESTÕES DE TRANSIÇÃO}

- No seu cotidiano de trabalho, quais os casos de violência contra a mulher é possível identificar? Fale sobre eles.

- Diante desses casos que vocês me relataram, o que vocês imaginam que desencadeia uma violência contra a mulher?

- Para vocês esses casos são realmente de violência doméstica contra a mulher? Por quê? 


\section{QUESTÕES CHAVES}

- Eu gostaria de saber também, como é que vocês lidam com essa situação? Como fazem aqui na UBS com casos assim?

- Por quais motivos vocês imaginam que uma mulher em situação de violência doméstica não denuncia?

- Vocês saberiam me dizer quais os serviços disponíveis na rede que essas mulheres podem buscar?

\section{QUESTÃO FINAL}

- Agora, fazendo um balanço... O quanto vocês acham que as políticas públicas sociais têm contribuído para a melhoria do atendimento das mulheres em situação de violência doméstica? 


\section{APÊNDICE 4 - ROTEIRO DO OBSERVADOR}

- Observar a linguagem corporal dos participantes, os sinais de concordância ou discordância, frustração e preocupação;

- Anotar as impressões sobre os participantes durante a discussão: suas reações, citações notáveis, ideias chaves e insights;

- Registrar atrasos e interrupções;

- Observar a dinâmica grupal e individual dos participantes;

- Relatar as características do grupo que venham a estimular ou inibir a interação grupal. 